INTERNATIONAL PHASE OF OCEAN DRILLING (IPOD)

DEEP SEA DRILLING PROJECT

TECHNICAL REPORT NO. 9

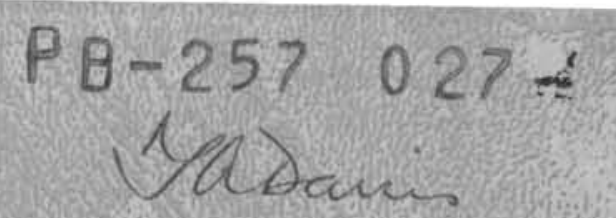

\title{
SOILS STUDY CONTINENTAL MARGIN SITES
}

BEARING CAPACITY STUDY OF SEAFLOOR SOILS, MIDDLE ATLANTIC RIDGE, ATLANTIC OCEAN

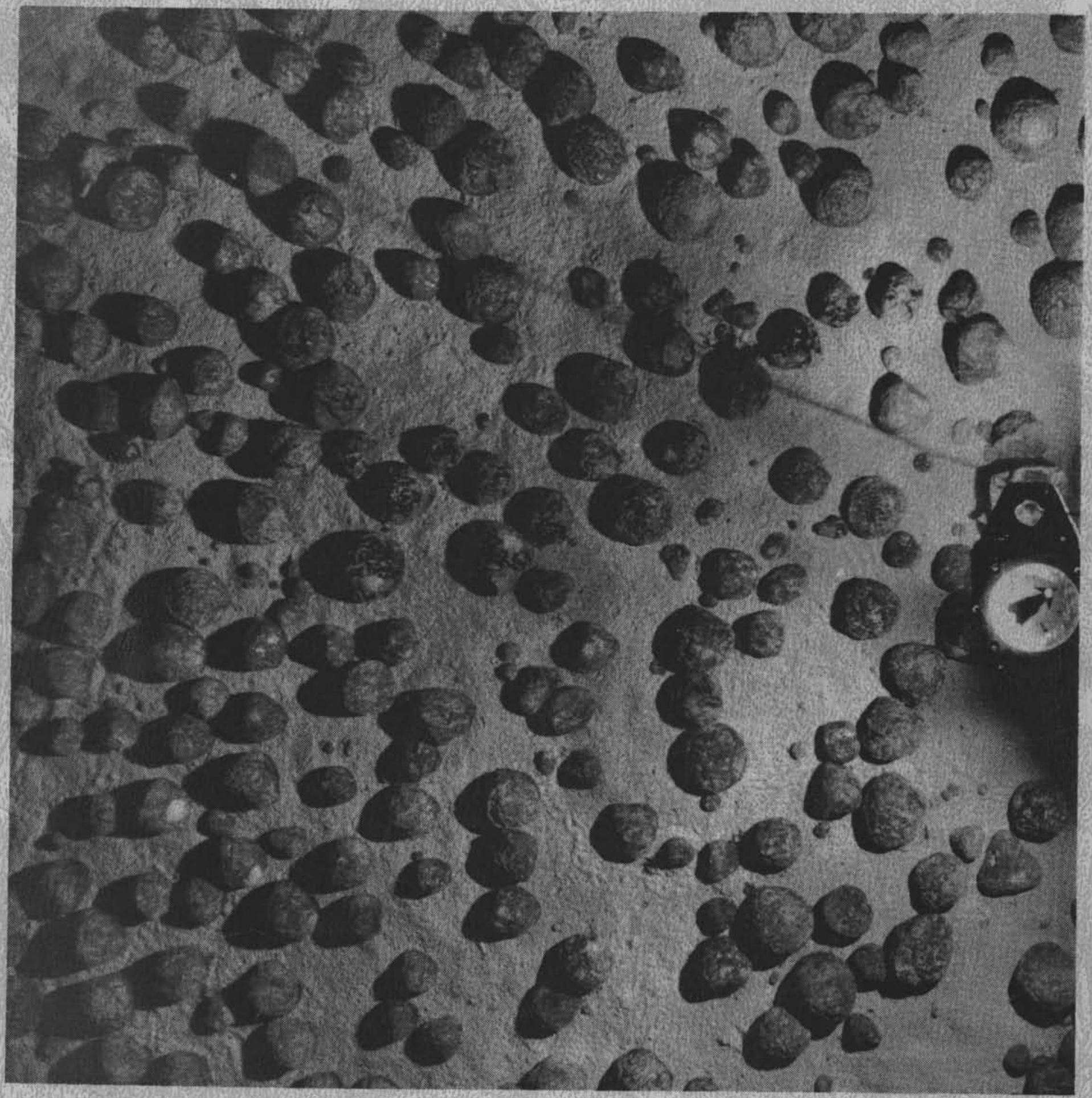

SCRIPPS INSTITUTION OF OCEANOGRAPHY UNIVERSITY OF CALIFORNIA AT SAN DIEGO 
THE COVER PICTURE

The cover picture shows manganese nodules lying on the bottom of the Atlantic Ocean at a water depth of 5,300 meters $(17,384$ feet). It appears through the courtesy of Dr. Bruce C. Heezen, of Columbia University's Lamont-Doherty Geological Observatory, Palisades, N.Y.

The photograph was taken by Dr. Heezen in the North Atlantic Basin, latitude $26^{\circ} 31^{\prime} \mathrm{N}$ and longitude $59^{\circ} 51^{\prime} \mathrm{W}$. 
TEECINICAI, RI:POR'T NO. 9

Prepared For

National Science Foundation

Under Provisions of Contract NSF C-482

By

Deep Sea Drilling Project

Scripps Institution of Oceanography

University of California at San Diego

August 1976

W. A. Nierenberg, Director

Scripps Institution of Oceanography
M. N. A. Peterson

Principal Investigator and

Project Manager

Deep Sea Drilling Project

Scripps Institution of Oceanography 
$\underline{\text { INTRODUCTION }}$

In this Deep Sea Drilling Project Technical Report No. 9, we are placing the public domain information generated by contract studies.

McClelland Engineers, Inc., of Houston, Texas completed the two studies for DSDP:

\section{Soils Study Continental Margins}

Bearing Capacity Study of Seafloor Soils Mid-Atlantic Ridge Atlantic Ocean

The foundation studies were made to evaluate foundation capacities of deep sea sediments for drilling oceanic margins while utilizing riser systems and to evaluate capacities of increasingly heavy re-entry hardware and casing strings for drilling oceanic basins and margins.

Original design re-entry cones and casing placed submerged loads of 15,000 pounds on the seafloor. Designs modified for deep penetration have suspended 65,000 pounds from the seafloor and loads up to 100,000 pounds are expected.

The reports contain engineering design data used in the evaluation of foundation capacities at Deep Sea Drilling Project sites.

Sediment samples for the two studies came from the DSDP West Coast Repository at Scripps Institution of Oceanography. 


\section{ACKNOWLEDGEMENTS}

Developed in the context of the placement of re-entry cones on the ocean bottom (DSDP Technical Report No. 2), the information contained in these reports by $\mathrm{McCl}$ lland Engineers, Inc., of Houston, Texas, may be of value in other deep sea operations.

Basic data for the two deep ocean soil studies was provided from the DSDP Data Bank under the supervision of Senior Programmer, Peter Woodbury. West Coast Repository Manager, Dennis Bohrer, provided assistance in sample selection and examination of material from stored cores.

The study was organized by the DSDP Development Engineering Group under the direction of Mr. Stanley Serocki. Overall supervision was provided by Mr. F. C. MacTernan as Principal Engineer and Deputy Project Manager.

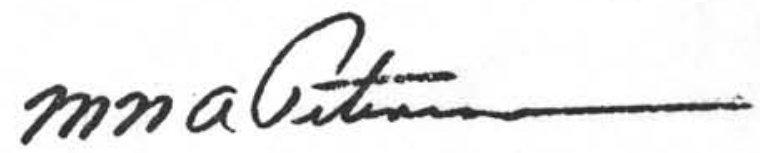

M. N. A. Peterson

Principal Investigator and

Project Manager

IPOD/DSDP/SIO 


\section{DEEP SEA DRILLING PROJECT SOILS STUDY \\ CONTINENTAL MARGIN SITES}

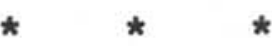

$$
\begin{gathered}
R \text { e p } \circ \mathrm{rt} \\
\mathrm{t}
\end{gathered}
$$

UNIVERSITY OF CALIFORNIA

DEEP SEA DRILLING PROJECT

La Jolla, California

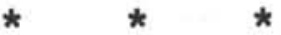

b y

M C C L E L L A N D E N G I NE E R S, IN C .

Geotechnical Consultants

Houston, Texas

June 1976 


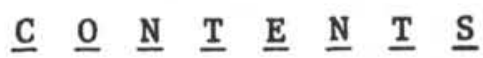

$\underline{\text { Page }}$

SUMMARY . . . . . . . . . . . . . . . . . . . .

INTRODUCTION

Background . . . . . . . . . . . . . . . . 1

Purpose and Scope of Study ............. 1

Report Format.................. 2

SAMPLE RETRIEVAL

Method of Sampling . . . . . . . . . . . . . 2

Core Handling and Storage . . . . . . . . . . . 3

Sample Disturbance ... . . . . . . . . . . . 3

SEDIMENT DESCRIPTION \& DATA REVIEW . . . . . . . . . . . 4

Review of Data from Continental Margin Sites . . . 5

Selection of Cores for Inspection... . . . . . 7

LABORATORY TESTS

Sample Inspection and Testing Selection . . . . . 7

Description and Results of Tests . . . . . . . 8

DISCUSSION OF STRENGTH TEST RESULTS

Torvane Tests... . . . . . . . . . . . . . . 9

Triaxial Tests . . . . . . . . . . . . . . . 10

Calcareous Ooze, Samples 41,50,73,74, and 78 . 10

Siliceous Ooze, Samples 65 and 68 ....... 11

Clay, Samples 55 and 61 ............... 12

GENERAL DISCUSSION OF OCEAN SEDIMENT TEST RESULTS

Water Content . . . . . . . . . . . . . 12

Calcareous Ooze............... . . 13

Siliceous Ooze . . . . . . . . . . . . . . . . . 14

Clay ..................... 14

Specific Gravity .. . . . . . . . . . . . 15

Untt Weight... . . . . . . . . . . . . . 16

Grain Size Distribution . . . . . . . . . . . 17

Sediment Plasticity . . . . . . . . . . . . 17

Clay ................... 17

Calcareous Ooze............... . . 18

Siliceous Doze ............... . . 19

Shear Strength . . . . . . . . . . . . . . 19

Cohesive Shear Strength........... 19

Sensitivity ................ . . . 22

Triaxial Tests . . . . . . . . . . . . . 23

Liquefaction and Cyclic Loading . . . . . . 24

Elastic Properties . . . . . . . . . . . . 25

Polsson's Ratio............... 25 


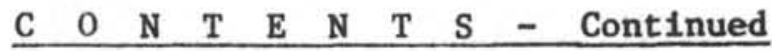

$\underline{\text { Page }}$

Modulus of Elasticity . . . . . . . . . . 25

Consolidation Characteristics . . . . . . . .

Depositional Characteristics .........

Engineering Characteristics . . . . . . . .

SOIL PARAMETERS: SUMMARY \& RECOMMENDATIONS . . . . . . . .

Recommended Design Parameter Values . . . . . . .

RECOMMENDATIONS FOR FUTURE WORK . . . . . . . . . . . .

Geotechnical Engineering Personnel . . . . . .

In Situ Testing................. 31

Sample Retrieval and Handling . . . . . . . . 32

Laboratory Testing . . . . . . . . . ...

APPENDIX A: REFERENCES

APPENDIX B: TRIAXIAL COMPRESSION TESTS

APPENDIX C: NOTATION 


\section{L L U S T R A T I O N S}

$\underline{\text { Plate }}$

Summary of Sample Description and Test Results . . . . . . . 1

Summary of Water Content Values from Present Study . . . . . 2

Plasticity Chart . . . . . . . . . . . . . . . . . 3

Grain Size Curve . . . . . . . . . . . . . . . . 4

Triaxial Compression Test Results ............. 5 thru 11

Torvane Test Results on Cohesive Materials . . . . . . . . . 12

Summary of Triaxial Test Results . . . . . . . . . . . 13

Summary of Water Content Values from DSDP Reports . . . . . . . 14

Summary of Unit Weight Values Derived from DSDP Water Contents • 15

Average Particle Size Distribution . . . . . . . . . . . . 16

Distribution of Clay Minerals in Ocean Floor Sediments . . . . 17

Shear Strength versus Penetration for Ocean Sediments . . . . 18

Compression Index Values for Ocean Sediments . . . . . . . . . . 19

Summary of Reported Results: Calcareous 0oze . . . . . . . . 20

Summary of Reported Results: Siliceous Ooze . . . . . . . . . 21

Summary of Reported Results: Clay . . . . . . . . . . . . 22

\section{Appendix - Illustrations}

Triaxial Testing Apparatus ................ . . A-1 


\section{SUMMARY}

The Deep Sea Drilling Project (DSDP) is making feasability and engineering studies for a possible continental margin coring program which w111 require development of a marine riser and well control capability. These capabilities will require, in turn, development of seafloor soil properties and related design parameters. The purpose of the present investigation is to establish these seafloor soil properties and design parameters for continental margin sediments on a worldwide basis. These data are also required to evaluate foundation requirements for re-entry cones and long casing strings being used during the present drilling program.

The investigation consisted primarily of (1) a review of available DSDP soils data from 900 cores from 89 continental margin sites to penetrations of $200 \mathrm{~m}$, (2) a program of laboratory testing of specimens from 48 selected DSDP cores, (3) a literature review of deep sea soils properties, (4) selection of appropriate solls properties and design parameters based on the results of the data review and laboratory tests, and (5) recommendations for future work. The following conclusions and recommendations were developed from this investigation.

(1) From the 89 continental margin sites reviewed, sediment distribution consisted of 48 percent calcareous ooze, 43 percent clay, 6 percent siliceous ooze and 3 percent ash. Water depths ranged from 193 to $6233 \mathrm{~m}$ with an average depth of $3160 \mathrm{~m}$. Sediments were completely unlithified to penetrations greater than $200 \mathrm{~m}$ at over 90 percent of the sites. At 21 of the sites, drilling was extended to the basalt crust which was encountered at an average penetration of $475 \mathrm{~m}$.

(2) Calcareous ooze is a sediment which comprises at least 30 percent skeletal material made up of calcium carbonate remains of mainly foraminifera and nannoplankton. The sediment falls generally within the silt and clay size particle range with foram ooze being coarser than nanno ooze. Pure calcareous ooze (1.e. 100 percent skeletal debris) appears to be essentially non-plastic; high plasticity measured in many calcareous ooze specimens probably reflects a high clay mineral content. Water content was found to decrease and unit weight correspondingly increase with penetration below the seafloor. Pure calcareous ooze has practically no cohesive shear 
strength; significant values of cohesion measured from calcareous ooze specimens are probably due to clay mineral content, inter-particle cementation, or confinement of the test specimen. For design purposes, the effective angle of internal friction should be taken as not greater than 20 and 25 degrees for nanno and foram ooze, respectively. The very limited data which exist to date on cyclic strength behavior of calcareous ooze suggest that it may be very susceptible to liquefaction. Values of elastic modulus appear to be dependent on confining pressure and grain crushing within the material. Many deep sea calcareous ooze samples exhibit "apparent overconsolidation", probably due to the formation of interparticle bonds over long time periods. Established relationships between compressibility, void ratio, water content and plasticity appear to be invalid for calcareous ooze.

(3) Siliceous ooze is a sediment which comprises at least 30 percent skeletal debris made up from the silica remains of mainly diatoms and radiolarians, falling generally into the silt and clay particle size range. As with calcareous ooze, pure siliceous ooze (i.e. 100 percent skeletal debris) is non-plastic, the high plasticity measured in many specimens being a function of their clay mineral content. Water contents of siliceous oozes are generally very high due to water entrapped within the spherical-shaped particles. Specific gravities fall below the normal range for soils, due to the low specific gravity of opaline silica. The high water content together with low specific gravity values combine to provide low unit weight values for the siliceous ooze. Only small variations in water content and unit weight were noted throughout the upper $200 \mathrm{~m}$ penetration, suggesting only minor in situ consolidation of the ooze within this depth. Pure siliceous ooze has little cohesive shear strength; the small vane strengths that have been recorded in this material are probably due to clay mineral content, inter-particle cementation, or confinement of the test specimen. For design purposes, the effective angle of internal friction should be taken as not more than 20 degrees. No tests have been performed to establish the cyclic strength properties of siliceous ooze; however, the particle size and looseness of the material suggest high susceptibility to liquefaction. Values of elastic modulus appear to be a function of confining pressure and grain crushing. Established relationships between compressibility, void 
ratio, water content and plasticity seem to be invalid for siliceous ooze.

(4) Clay material at the continental margin sites appears to be mainly terrigenous and hemipelagic, with some pelagic clays in evidence. The samples examined were generally very plastic, due possibly to a high montmorillonite content. Water content values were high, with correspondingly low unit weights. The water content decreased and the unit weight increased with penetration below the seafloor. Cohesive shear strengths examined were significantly less than for normally consolidated clays from the Gulf of Mexico continental shelf. For design purposes, the effective angle of internal friction should be taken as not more than 20 degrees. No tests have been performed to establish the cyclic strength response of continental margin clays; however, cyclic stress effects in clays do appear to be complex and much work is required to better understand the processes involved. Ratios of elastic modulus to cohesive shear strength appear to fall within established limits. As with calcareous ooze, many deep sea clay samples exhib1t "apparent overconsolidation", probably due to interparticle bonding over long periods of time. Where structures are supported by these materials, little settlement may occur until maximum apparent past pressure is exceeded, after which extensive settlement may result.

(5) Recommendations are given for obtaining more complete and more accurate engineering soils data from DSDP coring operations in the future. 
INTRODUCTION

B a c k 8 ro u n d

The Deep Sea Drilling Project (DSDP) is a part of the National Science Foundation's Ocean Sediment Program and is managed by the Scripps Institute of Oceanography of the University of California, San Diego. The purpose of the project is to make a broad reconnaissance survey of the ocean basins to obtain information about the history and origins of ocean basins and continents and the processes that led to their formation and modification. To this end, the dynamically positioned drill ship "Glomar Challenger" has been operated in a worldwide program of deep sea scientific coring since 1968 .

DSDP is making feasibility and engineering studies for a possible future program of scientific coring of the continental margins in the depth range of 2000 to $3000 \mathrm{~m}$. The program will require development of a marine riser and well control capability to these depths with a vessel and riser operational in 1981. In order to design adequately for the stability of the seafloor structures and the riser pipe, appropriate soil parameters must be provided. These parameters will also provide a basis for determining allowable loads of re-entry cones and long casing strings being used during the present "Glomar Challenger" drilling program.

purpose and Scope of study

The general purposes of this study are to establish seafloor soil properties and to furnish related design parameters for continental margin sediments on a worldwide basis.

The study includes:

(1) a review of the available DSDP soils data with respect to engineering properties,

(2) a laboratory testing program to provide additional information on engineering properties of continental margin sediments,

(3) comparison of the results from the laboratory testing program with results from the literature,

(4) selection of appropriate soil design parameters,

(5) provision of recommendations concerning future work. 
Report Format

The initial section of this report describes briefly the sampling method and sample storage system used in the DSDP; sample disturbance is discussed. Existing soils data are reviewed and the nature of marine deposits discussed. The process of sample selection for inspection and testing in our laboratory is outlined. The laboratory soil tests are then described and the results of the tests are presented in tabular and graphical form in 1llustrations which follow the text. The results of the tests are discussed and compared with existing deep sea soil test data. Based on the laboratory test results, existing DSDP soils data, and results reported in the literature for deep sea sediments, soil design parameter values are recommended. The report concludes with recommendations concerning future sampling and testing.

\section{SAMPLE RETRIEVAL}

Met hod of $\mathrm{s}$ a m p 1 in $g$

Sampling operations are performed with the drilling equipment on board the dynamically positioned drill ship "Glomar Challenger". Samples are recovered using a core barrel operated on a wire line through the bore of 5-in.-diameter S-135 drill pipe. The core barrel can obtain cores approximately $9.5 \mathrm{~m}$ in length with a core diameter of $2.5 \mathrm{in}$. A heave compensation system decouples the drill string from the vessel's vertical motion to minimize movement of the drill bit relative to the base of the borehole. Coring during the sampling operations was sometimes continuous and sometimes at discrete intervals.

Initially, tungsten-carbide drag-type core bits and diamond-studded core bits were employed in the coring operations. However, rapid dulling of these bits when in contact with chert has led to development of a tungstencarbide insert roller bit using standard rock bit components with the roller cutters moved apart to enable a core to be cut. Whenever a dulled bit needs replacement, necessitating withdrawal of the drill string, re-entry into the borehole is facilitated by lowering a 16-ft-diameter re-entry cone, which is equipped with sonar reflectors, to the ocean floor on the drill pipe. Re-entry into the borehole is accomplished by accoustically locating the cone with a scanning sonar transmitter-receiver which protrudes through the center bit hole at the lower end of the drill pipe. 
Core Hand 1 ing and Storage

After retrieval of the core barrel by wire line, the 9.5-m-long core, Inside a thin plastic liner, is removed from the barre1, properly orientated, labelled, and cut into $1.5-\mathrm{m}-1$ long sections. Various nondestructive tests are then performed on the core section aboard ship, after which the sections are split longitudinally. One half of each section is preserved for photographing and archival storage; the other half is used as a source of specimens for on-board studies and later for shore-based studies.

Cores from the Pacific and Indian Oceans, the Arabian and Red Seas, and some cores from the Antarctic Ocean are stored in the West Coast Repository, located at Scripps Institute of Oceanography, La Jolla, California. Cores from the Atlantic Ocean, Gulf of Mexico, Caribbean, Mediterranean and Black Seas, and some cores from the Antarctic Ocean are stored in the East Coast Repository, located at Lamont Geological Observatory of Columbia Unversity, New York. For storage, the split core sections in their plastic liners are sealed inside plastic half-cylinders at a temperature of approximately $4^{\circ} \mathrm{C}$; moist rags are inserted into the plastic containers in an attempt to prevent the core material drying out.

S a m 1 e Disturbance

Sample disturbance will create inherent problems in the interpretation of soil properties which are functions of the in situ stresses and structure of the material - for example, strength, elasticity, permeability and consolidation characteristics. Various aspects of sample disturbance have been extensively reported and discussed in the literature, for example by Hvorslev (1949) ${ }^{(1)}$, Emrich (1971) and Lee (1973a). In this section, we shall outline very briefly possible causes of sample disturbance in DSDP. Improvements to eliminate or minimize sample disturbance will be discussed in the final chapter.

Disturbance effects can be classed as mechanical disturbance due to sampling, disturbance from pressure release due to sample removal from in situ, and disturbance due to subsequent handling and storage effects.

(1) List of references in Appendix A. 
Mechanical disturbance effects are caused by the rotational and cutting action of the core barrel and are evidenced by remolding of the outside portion of the core (and sometimes even the whole core); less of this type of disturbance will result from piston-type sampling than rotary coring. Wall friction on the inside of the barrel or sample tube can cause compression of the core and also punching shear of the material immediately below the core.

Removal of the core from beneath the seafloor to the surface will cause (1) expansion of the pore water and dissolution of dissolved gas in the core due to hydrostatic pressure release, (2) formation of negative pore pressure in the core to resist expansion due to effective overburden pressure relief, and (3) possible cavitation of the pore water under this negative stress. For soft, high water content, gaseous sediments taken from deep penetrations in deep water, these combined factors can destroy much or all of the in situ structure.

Any rough handling of the core once on deck can cause severe disturbance; the routine longitudinal cutting of the liner plus core may also cause considerable structural disturbance. Change in temperature from around $4^{\circ} \mathrm{C}$ normal at seafloor to an on-deck temperature as high as $30^{\circ} \mathrm{C}$ will cause expansion of pore water and may trigger decomposition of any organic material in the core. Long-term storage can cause creep mechanisms to operate in the sample; vibrations due to refrigeration or air conditioning units in the sample storage area may accelerate this response (Lee, 1973a).

\section{SEDIMENT DESCRIPTION AND DATA REVIEW}

Marine sediments are diverse both in composition and texture. For classification purposes, they can be divided into two main groups termed terrigenous and pelagic deposits. Terrigenous deposits are found in shallow and deep water close to land masses and are derived from material eroded from the land surface, comprising mainly clay, silt, sand, and gravel sediments. Pelagic deposits are accumulated slowly in the open ocean and consist mainly of ooze or brown clay. An ooze is a sediment which comprises at least 30 percent skeletal remains of pelagic organisms; calcareous oozes are made up of the calcium carbonate remains of mainly foraminifera and nannofossils 
and occur most commonly around the equator, in the oceans south of the equator and in the North Atlantic; siliceous oozes consist of the silica remains of mainly diatoms with some radiolarians, with diatomic oozes occuring between latitudes 45 and 60 degrees and radiolarian oozes being found in deep equatorial regions of the Pacific Ocean. Brown (or commonly termed "red") clay is a deep ocean inorganic clay believed to be derived from either atmospheric dust blown great distances from the continents, terrigenous material transported great distances by the ocean currents, or material produced from solution in the ocean. Sometimes the seafloor materials contain amounts of terrigenous sediments as well as pelagic deposits; these are known as hemipelagic deposits. According to Herrmann et a1 (1972), terrigenous materials account for 26 percent of the total seafloor, calcareous ooze 36 percent, siliceous ooze 10 percent and brown clay 28 percent. It must be kept in mind that these figures are generalizations and that seafloor sediments frequently contain a combination of various types of deposited material, with one material predominant (usually that with the most rapid depositional rate).

Review of Data from Continental Margin Sites

At the commencement of this study, data from 31 legs, consisting of 302 sites worldwide, were available in published form. of these, data and samples from 89 sites on the continental margin were selected by Scripps Institute for review in this investigation. Samples from 56 of the sites were stored at the West Coast Repository at La Jolla and samples from the remaining 39 sites were stored at the East Coast Repository at Lamont.

Distribution of materials at the reviewed continental margin sites differs from the total seafloor distribution given in the last section. Two factors account for this difference, namely (1) a greater percentage of terrigenous material at the continental margin sites due to their proximity to land, and (2) smaller amounts of brown clay on the continental margins, this material being found generally at much greater distances from land. Sediment composition at the sites was reviewed to a depth of approximately $200 \mathrm{~m}$. Calcareous ooze was the predominant material at 48 percent of the sites, siliceous ooze at 6 percent of the sites, ash at 3 percent of the sites and clay (with some silt and sand) at 43 percent of the sites. The clay appeared to be mainly terrigenous and hemipelagic. 
Water depths at the 89 sites ranged from 193 to $6233 \mathrm{~m}$, with an average depth of $3160 \mathrm{~m}$. Water depths at the sites containing predominantly calcareous ooze ranged from 852 to $6233 \mathrm{~m}$ with an average depth of $2600 \mathrm{~m}$; at the sites where clays were predominant, water depths ranged from 193 to $6194 \mathrm{~m}$, with an average depth of $3730 \mathrm{~m}$.

Sediments were completely unlithified to penetrations greater than $200 \mathrm{~m}$ at over 90 percent of the sites. In many of the borings, unlithified material extended to penetrations of $700 \mathrm{~m}$ and beyond. In 21 of the borings reviewed, drilling was extended to the basalt crust; the crust was encountered at penetrations ranging from 190 to $910 \mathrm{~m}$, at an average penetration of $475 \mathrm{~m}$.

At most of the sites, the predominant sediment at the seafloor continued to predominate throughout the upper $200 \mathrm{~m}$. In less than 10 percent of the borings was there a major strata change within the upper $200 \mathrm{~m}$. At many of the locations, however, although one type of sediment was predominant, considerable variation of material composition existed within each core and even within each section; in these cases, the variation was usually in evidence throughout the entire $200 \mathrm{~m}$.

From the 89 continental margin sites, data from approximately 900 cores were reviewed. These data contained the geologic age and 1ithologic description of each core, along with information on the core composition which was obtained from smear slides, x-ray minerology tests, carbon-carbonate tests and grain-size analyses; sediment texture was determined from smear slide tests and grain-size analyses techniques.

Data on bulk density (or unit weight) and porosity of the cored sediments were obtained routinely on board "Glomar Challenger" by a Gamma Ray Attenuation Porosity Evaluator (GRAPE). Bulk density was also measured on board by weighing the 1.5-m-1ong sections on a triple beam balance; in addition, bulk density was measured by weighing material withdrawn from the split core by a very small syringe (1 to $2 \mathrm{cc}$ ). Water content and related porosity determinations were made on these small syringe samples. Grain densities were usually calculated from the water content and bulk density measurements.

Vane shear strength measurements were made on board on selected "undisturbed" portions of cores at 15 of the sites reviewed. Consolidation tests were later performed on shore on samples from 6 of these sites and one 
consolidated-undrained triaxial compression test was made on shore. In addition, more precise measurements than normal were made of bulk density, water content and grain density of samples from these sites.

These data will be discussed and compared in a later chapter of the report.

\section{Selection of Cores for Inspection}

The primary purpose of this study was to assign suitable values to engineering design parameters of continental margin soils. Of the 900 cores reviewed, 75 were selected for inspection. These cores contained samples of the marine sediments described in the previous sections, i.e. calcareous and siliceous ooze, ash and terrigenous and hemipelagic clay. Selection was weighted generally towards the cores which appeared, from the data reviewed, to contain materials which might exhibit foundation problems, e.g. materials with high water contents, low unit weights or low strengths. The cores selected for inspection were from 11 continental margin sites on the east and west sides of both the Indian and Pacific Oceans and were stored at La Jolla. In addition, a 6.4-m-1ong piston core obtained by the research vessel "Atlantis 2" from a location on the Mid-Atlantic Ridge, under the supervision of Woods Hole Oceanographic Institution, was inspected at Woods Hole, Massachusetts.

\section{LABORATORY TESTS}

\section{Sample Inspection and Testing Selection}

The seventy-five cores were inspected by our engineer at the West Coast Repository at La Jolla between October 13 and 15, 1975. The sections of the cores with least apparent disturbance were selected for testing purposes. Torvane tests were performed on portions of the sections to provide a shear strength assessment of cohesive sediments. Following inspection of the cores, 72 samples from 48 cores were selected for testing in our Houston laboratory. Twenty-four of these weighed approximately $100 \mathrm{~g}$ each and were sealed into plastic bags; the remaining 48 samples were contained in small plastic vials and weighed about $10 \mathrm{~g}$ each. 
The 6.4-m-long core from the Mid-Atlantic Ridge was inspected by our engineer at Woods Hole Oceanographic Institution on November 24, 1975. Torvane tests were performed on portions of the core; at this time the core had not been split. Five thin-walled stainless steel tubes, each 1-1/2 in. in diameter and $3 \mathrm{in.}$ in length were pushed into the material to obtain suitable samples; each of these tube samples weighed about $140 \mathrm{~g}$. In addition, two $250-\mathrm{g}$ bag samples were taken from the core. Details of the core are presented in our Report No. 175-361.

The samples selected for testing from La Jolla and Woods Hole were carefully packaged and hand carried by our engineer to Houston. These samples are tabulated below with respect to the major marine sediment groups described previous1y.

Sediment Type

Calcareous ooze

Siliceous ooze

Clay, silt

Ash

\begin{tabular}{crr}
$\begin{array}{cc}100 \mathrm{~g} \\
\text { bag }\end{array}$ & & $\begin{array}{c}10 \mathrm{~g} \\
\text { vial }\end{array}$ \\
\cline { 1 - 1 } 8 & & 11 \\
8 & & 18 \\
6 & & 16 \\
2 & 3
\end{tabular}

Number of Samples

$140 \mathrm{~g}$

al tube bag

A complete sample list, which includes general descriptions based on DSDP and Woods Hole reports, water depths, sample penetrations and site locations is presented on Plate 1.

Description and Results of Tests

The types and numbers of soil tests performed in our laboratory are tabulated below:

Type of Test

Water Content

Atterberg Limit

Specific Gravity

Hydrometer Analysis

Consolidated-Undrained Triaxial

Compression with Pore Pressure

Measurements

Single Stage

Multiple Stage

\section{Number of Tests}

62

19

11

1
2

$-$

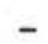


Water content and unit weight determinations were made for most of the specimens subjected to the triaxial tests. Brief descriptions of the procedures used to perform the triaxial tests are presented in Appendix B. The results of the water content, Atterberg limit and specific gravity determinations are presented on Plate 1; the shear strength values obtained from Torvane tests by our engineer on cohesive soils inspected at La Jolla and Woods Hole are also given on these plates. The water content determinations are summarized on Plate 2 in terms of the major sediment groups. The Atterberg limit results are plotted on a plasticity chart on Plate 3 . The grain-size distribution from the results of the hydrometer analysis is presented on Plate 4. The results of the triaxial tests are presented in the form of stress-strain curves, pore pressure-strain curves and Mohr circles, along with test details on Plates 5 through 11; refer to Appendix C for notation used on these plates.

\section{DISCUSSION OF STRENGTH TEST RESULTS}

The brief discussion in this chapter is limited to the strength tests performed for the present study. A more general discussion and comparison of all results obtained from the literature and the present study will be presented in the next chapter.

Torvane Tests

The results of Torvane tests performed on materials classified as clays or silty clays on the plasticity chart on Plate 3 are presented on Plate 1. The Torvane results are plotted as shear strength versus penetration on Plate 12. Of primary interest on this plot are the points representing the clay materials; the nine ooze strengths plotted are for clayey oozes which appear to behave as cohesive materials in contrast to the large majority of the oozes inspected which were non-cohesive. Although a distinct trend of increasing strength with penetration in the clays is evident, the results exhibit wide scatter, which is to be expected since (1) the clay materials came from five sites worldwide and consisted of varying amounts of different clay minerals deposited under widely varying conditions, and (2) the samples were all disturbed to some extent, although the degree of disturbance depended very much on the conditions during sampling and on subsequent core handling and storage, as discussed previously. 
Tr i a x 1 a 1 T e s t s

The only triaxial tests which were performed on "undisturbed" specimens were the tests on clay rich nanno ooze from the Woods Hole unsplit cores (samples 73, 74, and 78). Although structural disturbance of this cored material is present due to factors discussed previously, it may be assumed that the in situ structure has remained partially intact. On the other hand, the remainder of the triaxial tests were performed on completely remolded samples whose in situ structure had been entirely destroyed; this remolding was necessary since "undisturbed" triaxial specimens could not be obtained from the split DSDP cores. The parameters obtained from the tests on "undisturbed" specimens will probably be more representative of the in situ parameters than those from the remolded tests.

The results of triaxial tests are summarized on Plate 13. The slopes of the Mohr envelopes of total and effective stresses, $\phi_{c u}$ and $\phi^{\prime}$, respectively, can be interpreted as a measure of the angle of internal friction between particles in the undrained and drained states, respectively. Effective stresses are obtained by subtracting pore pressure values from total stress values. The pore pressure parameter, $A_{f}$, for the saturated samples in these tests is equal to the increment of pore pressure, measured at failure, divided by the increment of compressive stress at failure, $\Delta u /\left(\Delta \sigma_{1}-\Delta \sigma_{3}\right)$. Values of $A_{f}$ can be used to interpret the degree of consolidation of undisturbed cohesive soils and the relative density of granular soils. The elastic modulus, E, is a function of the stress-strain characteristics of the material; the higher the value of $\mathrm{E}$, the lower will be the elastic settlement or deflection of the soil under loading. $\mathrm{E}_{50}$ is a measure of the elastic modulus at 50 percent of maximum stress in the triaxial tests. $2 \mathrm{E}_{50} /\left(\sigma_{1}-\sigma_{3}\right)$ is the inverse of the strain in the specimen at 50 percent maximum stress; it is often relatively independent of consolidation pressure and approximately constant for each particular type of material.

Calcareous Ooze, Samples 41, 50, 73, 74, and 78. A common feature of all of the tests on calcareous ooze is the shape of the stress-strain curves (Plates 5 through 7). A sharp change in slope is indicated generally between 0.5 and 1.0 percent strain; this slope change suggests some rearrangement of the sample structure, possibly involving fracture or breaking of individual 
particles. In the multiple-stage tests on recompacted samples (41 and 50), the change in slope is more pronounced in the initial stage; it appears probable that the rearrangement of the particles during the first stage produced a more stable sample structure for the second and third stages.

The Mohr envelope for sample 50 on Plate 6 indicates a value of total shear stress of $8 \mathrm{psi}$ at zero normal stress, i.e. an unconfined specimen of the material will possess a cohesive strength of $8 \mathrm{psi}$; the cohesiveness of this sample is indicated by its position on the plasticity chart on Plate 3 . For sample 41, which is non-plastic, the Mohr envelope shown on Plate 5 passes through the origin as expected. The effective angles of friction $\phi^{\prime}$ for all the calcareous oozes is relatively consistent, ranging between 38 and 42 degrees. However, the total friction angle $\phi_{c u}$ for the recompacted samples ranges between 25 and 29.5 degrees, much lower than $\phi_{\text {cu }}$ of 40 degrees obtained from the "undisturbed" samples. This can be attributed to different pore pressure responses between the "undisturbed" and recompacted specimens; initial pore pressure buildup is quickly dissipated in the "undisturbed" specimens and pore pressure even becomes negative at failure in one specimen. The low $A_{f}$ values for the "undisturbed" specimens indicated on Plate 13 reflect these low pore pressures at failure.

The $2 \mathrm{E}_{50} /\left(\sigma_{1}-\sigma_{3}\right)$ ratio for the single-stage samples 73,74 and 78 shown on Plate 13 is relatively constant. However, for multiplestage samples 41 and 50 the values increase significantly with each stage. This increase may be related to the more stable soil structure produced in the second and third stages of these tests as discussed earlier; the more stable structure will result in smaller strains in the samples and correspondingly higher $2 E_{50} /\left(\sigma_{1}-\sigma_{3}\right)$ values.

Siliceous Ooze, Samples 65 and 68 . These tests are characterized by high strains to failure, correspondingly low $2 \mathrm{E}_{50} /\left(\sigma_{1}-\sigma_{3}\right)$ ratios and relatively high $A_{f}$ values for granular materials; these factors indicate the ooze to be in a loose state during testing. The sharp change in slope of the stress-strain curves noted in the calcareous ooze tests was not apparent In the siliceous ooze; however, the values of $\phi_{\mathrm{cu}}$ and $\phi^{\prime}$ recorded for the siliceous ooze are of the same order as those for the recompacted multiplestage calcareous ooze tests. 
Clay, Samples 55 and 61 . The two samples of clay tested, although obtained from different areas of the world, give similar results. This can be attributed in part to the completely remolded state of the tested samples, with any in situ structure differences eliminated. Because of the remolding, the values of $A_{f}$ cannot be used to interpret in situ degree of consolidation. The values of $\phi_{\mathrm{cu}}$ and $\phi^{\prime}$ are much lower than for the granular oozes, which is not unusual since the slope of the Mohr envelope in cohesive soils reflects the greater interparticle bonding caused by increased consolidation and reduced void ratio rather than the angle of internal friction inherent in granular materials. Frequently the increase in interparticle bonding with consolidation of cohesive soils in less pronounced than the frictional increase noted in granular soils.

\section{GENERAL DISCUSSION OF OCEAN SEDIMENT TEST RESULTS}

In this chapter we shall discuss results of ocean sediment tests from the 1iterature and compare them, where applicable, with the test results from the present study. This discussion, and the results presented and compared herein, will form the basis of the recommended soil parameter values presented In the next chapter.

Water content

Water content of a soil is defined as the weight of water in the soil divided by the weight of soil solids, expressed as a percentage. The water content of granular soils is important mainly because of its influence on the unit weight of the soil; for cohesive soils, water content of ten relates to shear strength and also mineral composition. Until recently, investigation of water content of ocean sediments has been confined to the uppermost few meters of material. Surface cores have been obtained over wide areas of the major oceans and seas and have been reported in the literature in terms of both spatial distribution and sediment type. Keller (1969) examined 300 sediment cores from the North Atlantic and 200 from the North Pacific basins and noted water contents ranging between 50 and 100 percent in the North Atlantic and 100 to 200 percent in the North Pacific; these values were for total ocean space. Hermann et al (1972) have reported Keller's results in terms of sediment type; for terrigenous materials and siliceous oozes they 
Indicate water contents between 50 and 100 percent, for calcareous oozes between 100 and 200 percent, and for brown pelagic clays extremely variable but as high as 300 percent. Keller (1971) has reported water content determinations on 67 seafloor cores of glacial-fluvial silty and sandy clays from the Greenland-Norwegian basin; water content values were normally between 40 and 70 percent.

With the advent of DSDP, extensive water content information has been obtained from cores extracted from various penetrations below the ocean floor. Bennett and Keller (1973), in their physical properties evaluation of the Leg 16 cruise, criticized the equipment used for the water content determination prior to the Leg 16 cruise and concluded that water content measurement by DSDP prior to that cruise may be suspect. Lee (1973b) compared 49 water content measurements taken on board during Leg 19 with accurately measured shore laboratory water contents on samples from the same core interval. The absolute difference in water contents expressed as a percentage of the shore laboratory measurements was about 7 percent. However, the on-board measurements were both higher and lower than the shore measurements and, measured algebralcally, the average on board measurement was about 2 percent less than the shore measurement. The water contents reported by DSDP make no correction for salt content in the water and thus the water contents discussed below are a measure of the ratio of water weight to dry sediment plus salt weight.

We have analyzed water content data obtained on board ship from cores from 70 sites selected for review in this study; in all, 470 water content measurements were reviewed. Primary causes of variation encountered in these water contents were (1) sediment type, (2) sediment penetration, and (3) location. We shall present results of the water content analysis in terms of the major sediment types and discuss variation within each type caused by differences of penetration and location.

Calcareous Ooze. Water content data from 309 samples of calcareous ooze from 39 sites worldwide were analyzed. The results of the analysis are summarized on Plate 14 . To obtain the average values indicated on Plate 14, average water contents and average sample penetrations were computed for each site and the overall average was obtained from these site averages; the 
standard deviations of the averages were similarly obtained. Variation of water content of calcareous ooze with penetration was studied by analyzing data from sites which had one or more water content determinations in both the upper $20 \mathrm{~m}$ and between 160 and $200 \mathrm{~m}$ penetration. In a11, 18 sites fell into this category. From the results indicated on Plate 14, the average decrease in water content of calcareous ooze with penetration was around 1.65 percent per $10 \mathrm{~m}$. The water content at $77 \mathrm{~m}$, 1inearly interpolated from these results, was about 68 percent; this is in good agreement with the overal1 average of 66 percent at $77 \mathrm{~m}$ obtained from the 39 sites.

The results were analyzed in terms of location worldwide. Seventyeight percent of the data were obtained from cores from the Pacific Ocean, Indian Ocean and Arabian Seas, giving average water content values of 77, 72 and 62 percent, respectively, at average penetrations of 67,100 and $84 \mathrm{~m}$, respectively. This compares well with an average water content of 75 percent at $54 \mathrm{~m}$ obtained in the present study of calecareous ooze samples from mainly these areas as shown on Plate 2. It was considered that the remaining 22 percent of the water content results, obtained from cores from six major ocean and sea areas, were insufficient in number to provide significant correlation of water content and location.

Siliceous 0oze. Water content data from 23 samples of siliceous ooze obtained from 8 sites were analyzed. The results of the analysis are summarized on Plate 14. Twenty-one of the samples were of diatom ooze from the Bering Sea or the Sea of Japan; the remaining two samples were of radiolarian ooze from the Indian Ocean, southwest of Java. The water content of the radiolarian ooze was of the same order as the diatom ooze. The overall average of 135 percent for siliceous ooze indicated on Plate 14 is somewhat lower than the 164 percent average obtained from a smaller number of tests in the present study as shown on Plate 2. These very high water contents are attributed to water entrapped within the generally spherical, hollow siliceous skeletons. As with the present study, no trend of decreasing water content with penetration was observed.

Clay. Water content data from 138 samples of clay and silty clay from 36 sites worldwide were analyzed. The results of the analysis are summarized on Plate 14. The large standard deviation of the overall 0 to $200 \mathrm{~m}$ average value can be attributed not only to variation in sample penetration but also 
to the wide range in material composition encountered at different locations, e.g. low water content carbonate clays in the Red Sea, medium water content terrigenous clay in the Gulf of Mexico and high water content diatom rich clays in the Bering Sea and hemipelagic clays in the Atlantic Ocean. The overall average water content for clay of 85 percent at $87 \mathrm{~m}$ shown on Plate 14 compares well with the 85 percent at $54 \mathrm{~m}$ obtained from a smaller number of tests in the present study as shown on Plate 2.

As with the calcareous ooze, variation of water content of the clay with penetration was studied by analyzing data from sites which had one or more water contents determined in both the upper $20 \mathrm{~m}$ and between 160 and $200 \mathrm{~m}$ penetration. Unfortunately only 9 sites fell into this category; nevertheless, the results from this limited sample are presented on Plate 14 for completeness. The average values indicate a decrease in water content of about 2.2 percent per $10 \mathrm{~m}$. The water content at $87 \mathrm{~m}$ penetration, linearly interpolated from these results was about 80 percent; this agrees well with the overall average of 81 percent at $87 \mathrm{~m}$ obtained from the 36 sites.

Specific Gravity

The specific gravities of most soil sediment grains fall between 2.6 and 2.85. Specific gravities of coarser grained materials such as sands and gravels can usually be assumed around 2.65 and clays around 2.75 (Scott, 1963). Keller and Bennett (1973) have reported grain specific gravities as low as 2.30 for siliceous oozes, since they are primarily composed of opaline silica with a specific gravity of 2.10 . The results of the specific gravity tests presented on Plate 1 for this study agree substantially with the above values.

For the DSDP reports, grain specific gravities were often calculated from the equation relating grain specific gravity, total unit weight and water content measurements; with this method, any small error in unit weight or water content measurement can lead to large errors in the calculated specific gravity values. As a result, specific gravity values reported by DSDP often range from about 2.5 to as high as 4.0 at the same site, with occasional extreme values (e.g. 17.22 at Site 192). Thus, for the present study, grain specific gravities reported by DSDP will not be used; instead, grain specific gravities will be assumed as 2.7 for calcareous ooze, 2.45 for siliceous ooze and 2.75 for clay. 
U n $1 \mathrm{t}$ W e $1 \mathrm{ght}$

Three types of unit weight are discussed in this section. Total unit weight refers to the total weight of both soil and water per unit volume. Submerged unit weight is the buoyant weight per unit volume as measured below water and equals the total unit weight less the unit weight of water; submerged unit weight is of particular importance when dealing with seafloor soils and structures. Dry unit weight is the weight of the soil grains alone per unit volume and is equal to the total unit weight divided by unity plus water content (expressed as a decimal).

Bennett and Keller (1973) reported comparisons of GRAPE measured unit weights with shore-based laboratory data and concluded that there is larger disagreement than desirable and that GRAPE scatter is random and unpredictable. Lee (1973b) compared GRAPE densities of 209 samples from Leg 19 with accurate shore laboratory measurements. The average GRAPE measurement was 3.4 percent less than the shore value. Bennett and Keller also found that unit weight measurements on board ship of both the 1.5-m-1ong sections and the small syringe samples were liable to considerable error. In the case of the $1.5-\mathrm{m}$ sections, errors were caused by changes in core liner geometry and possible voids in the core; for the syringe samples, volume calibration of the syringe was found to be frequently in error.

Due to the possible inaccuracies of measured unit weight noted above, we decided not to analyze the unit weight values presented in the DSDP reports. Instead, we derived unit weight values based on the water contents reviewed previously (summarized on Plate 14), using the simple relationship which exists between water content, unit weight and specific gravity for saturated soils. In this relationship we assumed the specific gravity values for the various sediments as noted in the previous section, although, in fact, the value of derived unit weight is insensitive to small variations in assumed specific gravity. As noted previously, Bennett and Keller (1973) and Lee (1973b) have observed inaccuracies in on board water content measurement; nevertheless, since water content determination is independent of sample volume and therefore obviates any volume measurements and errors associated with these measurements, we belleve the derived unit weights to be a more accurate reflection of the in situ unit weight than the DSDP measured unit weights. 
The derived values of unit weight are summarized on Plate 15. The low values for siliceous ooze reflect both the high water content values and, to a lesser extent, the low specific gravity of this material. The ocean floor sediment values of unit weight presented by Herrmann et al (1972) are in substantial agreement with the values on Plate 15 for the upper $20 \mathrm{~m}$.

Gra $1 \mathrm{n}$ S ize Distribution

DSDP has performed grain size analyses on samples from the majority of cores recovered in the coring operations, including analyses of specimens from 30 of the 48 cores selected for testing in our Houston laboratory; the results of the analyses on the 30 cores are shown on Plate 16. The particle size limits used by DSDP and noted on Plate 16 are based on the Wentworth scale. The grain size distributions were obtained using the standard hydrometer technique (Lambe, 1951) in which it is assumed that particles are solid spheres which settle out of water at a rate given by Stoke's Law for laminar flow. Lee (1973c) observes that for diatoms, which are generally porous spheres, the actual rate of settling is probably lower than theoretically predicted, resulting in an overestimation of fine-grained materials; this observation can be applied also to many of the nanno plankton and foraminifera which make up calcareous ooze.

Considerable variation of grain size is observed, even within individual sediment groups, due to the large number of different particle types and sizes which make up each group. For example, in the case of: calcareous ooze, nannofossils may range in size from 1 to 15 microns and foraminifera may range from 10 microns for micro-forams to 2000 microns for the larger forams. It can therefore be misleading to generalize about grain size distribution within any one sediment group. The average results on Plate 16 should be viewed with this in mind.

Sediment P l a s t icity

Since liquid and plastic limit measurements do not require undisturbed samples, any relationship which can be developed between these limits and the engineering properties of the undisturbed material will be valuable.

Clay. For cohesive soils, plasticity values and the relationship between these values and the natural water content of the clay can provide information about the structure and mineralogy as we11 as the shear strength 
of the clay. The degree of plasticity of the soll reflects the strength of the Interparticle bonds within the soll; these bonds, in turn, are a function of the structure and mineralogy of the soil. Thus, different clay types will exhibit different plasticities. Lambe (1969) has shown values of plasticity Index, i.e. 1iquid limit minus plastic 1imit, for the clay mineral kaolinite ranging from 11 to 28 , for illite from 49 to 63 and for montmorillonite from 220 to 650 . To demonstrate mineral content variation with location, Griffin et al (1968) tabulated the average concentration of pelagic brown clay minerals in the major oceans and this table is reproduced on Plate 17; according to Fukuoka and Nakase (1973), volcanic debris materials are degraded upon contact with sea water to produce montmorillonite, which accounts for its higher concentration in the southern oceans. We may conclude that, in general, because of their higher montmorillonite content and corresponding higher plasticity, the pelagic clays in the southern oceans are generally more plastic than in the northern oceans. For terrigenous clays, mineral content and corresponding plasticity will depend upon the continental sources of the material and therefore vary extensively throughout the different regions of each ocean.

Plasticity of clays has been related to shear strength by Bjerrum and Simons (1961) who have plotted the effective angle of shearing resistance against plasticity index for over 50 samples of normally consolidated clays and have found that the friction angle decreases with increasing plasticity. McClelland (1966) has related the cohesive shear strength of normally consolidated Gulf of Mexico clays to the 1iquidity index, i.e. the ratio of natural water content minus plastic limit to the plasticity index, and has shown that the shear strength of the clays increases with decreasing values of liquidity index.

Keller and Bennett (1973) performed two Atterberg limit tests on zeolitic clays from DSDP Sites 160 and 163 and obtained plasticity values similar to the high values obtained from Atterberg limit tests on clays in the present study shown on the plasticity chart on Plate 3; these high values probably reflect the mineral content of the clays as discussed above.

Calcareous Ooze. Keller and Bennett (1973) carried out Atterberg limit tests on six calcareous ooze samples from DSDP Sites 158, 160, 161 and 162 with a resulting spread of plasticity values similar to those obtained in 
the present study as indicated on Plate 3; one test indicated a very plastic organic clay, while the other five indicated organic silts and low plasticity organic clays.

Pure calcareous ooze can be categorized as a non-plastic or lowplasticity organic silt, with lowest plasticity occurring in the samples with a preponderance of larger forams e.g., sample 41, Plate 3 . However, since an ooze is defined as a sediment with at least 30 percent organic skeletal material, the remaining 70 percent of the sediment can have a strong influence on its plasticity characteristics. Many Atterberg limit tests on calcareous ooze reported in the literature record high plasticity values; these values probably indicate the presence of a substantial amount of highly plastic clay minerals such as montmorillonite among the skeletal debris rather than plasticity inherent in the pure ooze. Demars et a1 (1976). found that, for calcareous oozes obtained from the eastern portion of the Atlantic Ocean, specimens with carbonate contents greater than 40 percent exhibit granular behavior and less than 40 percent exhibit cohesive behavior.

Siliceous Ooze. Lee (1973c) performed Atterberg limit tests on 12 samples of diatom ooze from 6 sites on Leg 19. He listed the pure diatom ooze as non-plastic and noted that the ooze liquefied easily when shaken, reacted as a very stiff material during liquid limit test groove cutting, and was not cohesive enough to remain intact during plastic limit testing. Where clay rich ooze or clayey ooze samples were tested, a considerable range in plasticity values resulted, comparable with that obtained in the present study as indicated on $\mathrm{P} 1$ ate 3 ; this range can be attributed to different quantities of clay minerals in the samples.

She ar Strength

Cohesive Shear Strength. Cohesive shear strength tests have been performed on piston and gravity cores obtained from the upper few meters of most of the major ocean and sea areas and are reported fairly extensively in the literature. These tests have been conducted on cohesive, partly cohesive and granular soils, of ten with no apparent differentiation given between purely cohesive and frictional effects. As would be expected, large variations of shear strength have been observed, reflecting not only different sediment types and testing control, but also the different methods of sampling and sample handing with varying degrees of resulting sample disturbance. Almost 
all of the test results indicate soft or very soft materials; since most seafloor solls have never been subjected to overconsolidation effects (excluding "apparent overconsolidation" which will be discussed in a later section), low shear strengths of the upper solls must be expected.

For the upper few meters of seafloor soils, Keller (1969) indicates that shear strengths obtained from 500 cores from the North Atlantic and North Pacific Oceans range from less than 0.07 to $0.35 \mathrm{ksf}$. He concludes that for seafloor sediments, (1) shear strength values are generally higher along the basin margins and in the lower latitudes, (2) North Atlantic sediments possess relatively higher shear strengths than those of the North Pacific, and (3) strength of calcareous oozes increases with increasing calcium carbonate content. The results of Keller's tests are summarized by Herrmann et al (1972) and are reproduced below:

\begin{tabular}{lc} 
Sediment Type & Shear Strength, \\
\cline { 2 - 2 } Terrigenic & 0.006 to 0.36 \\
Brown Clay & less than 0.07 \\
Siliceous Ooze & 0.07 to 0.22 \\
Calcareous Ooze & 0.07 to 0.14
\end{tabular}

It is not made clear whether the strengths of the siliceous and calcareous ooze in the above table can be attributed to interparticle cohesive forces in the pure ooze (i.e. 100 percent skeletal debris), to the cohesion of any clay material mixed with the ooze, or to confinement of the sample during testing.

In situ vane tests by Lee (1976) on foram ooze from near the seafloor in the Western North Atlantic gave shear strengths as high as $0.6 \mathrm{ksf}$. When sampled, however, the material was found to be virtually cohesionless and gave very low laboratory vane strengths. Lee concluded that the high in situ strength was due to the overburden pressure effect.

Lee (1973d) conducted a series of miniature vane tests on two box core samples of brown clay from the Pacific Ocean and obtained strengths ranging from 0.1 to $0.2 \mathrm{ksf}$, in contrast to the maximum of $0.07 \mathrm{ksf}$ obtained by Keller on gravity and piston core samples. Lee concludes that (1) gravity and piston cores disturb the soll significantly, (2) $0.07 \mathrm{ksf}$ for the in situ strength of seafloor brown clay is probably far too low, and (3) the actual in situ strengths may be slightly higher than those measured from the box core. 
Not all seafloor clays are soft. Where the clays have been overconsolidated, high shear strengths will result, even in the upper few meters. In the overconsolidated clays of the North Sea for example, seafloor shear strengths of greater than $3 \mathrm{ksf}$ are of ten recorded. However, overconsolidated seafloors are uncommon and we know of nc truly overconsolidated deep ocean floors.

During the DSDP cruises, on board shear strength measurements were performed on cores from 15 of the sites under review in the present study. Tests were performed on cores of calcareous and siliceous ooze as well as clays. As with the seafloor sample strengths tabulated above, it is not made clear whether the shear strengths of the oozes are a reflection of actual cohesive forces between skeletal particles, cohesion of clay mixed with the skeletal debris, or, with cores from deeper penetrations, residual confining effects of the overburden pressure. Typical profiles of shear strength with penetration are presented on Plate 18 for on board strength measurements; also depicted are Torvane shear strengths of clay samples from the present study and a shear strength curve of miniature vane and unconfined compression tests on normally consolidated clays from many areas of the continental shelf of the Gulf of Mexico as presented by McClelland (1966). On Plate 18 the curves from Bouma and Moore (1974) and Rocker (1974) indicate the maximum shear strength envelopes obtained from large numbers of tests; the curve from the present study also indicates the maximum shear strength envelope estimated from the results given on Plate 12. In view of the large amount of sample disturbance inherent in the deep sea coring operation, as discussed previously, we consider that these maximum values may be a more realistic reflection of in situ values than average values obtained. The curve from Lee (1973c) represents results corrected, to some extent, for sample disturbance.

The DSDP clay strengths indicated on Plate 18 were obtained from normally consolidated clays, but indicate strengths less than half those of the normally consolidated Gulf of Mexico clays. Water contents of most DSDP clays are generally higher and unit weights correspondingly lower than the Gulf of Mexico clays, primarily due to different mineral composition. It cannot be estimated how much the apparent difference in shear strength can be attributed to a difference in mineralogy and how much is due to the greater degree of sample disturbance generated in deep water cores. 
The diatom ooze strengths from both sources shown on Plate 18 are extremely low; these low strengths are probably due to either (1) only a small amount of clay binder in the ooze, (2) no binder at all but some degree of confinement during the tests, and/or (3) some degree of cementation between the particles. Although the calcareous oozes on Plate 18 exhibit higher strengths than those of the diatom oozes, their strengths can probably be attributed to one or more of the three causes outlined above; since the submerged unit weights of the calcareous oozes are approximately double those of the diatom oozes, any consolidation of clay minerals or any residual confining pressures in the sample due to overburden will be correspondingly greater. Bouma and Moore (1974) suggest that the higher strength of the calcareous ooze is probably due to incipient cementation and note that Roth and Thierstein (1972) have observed slight degrees of secondary calcite overgrowth of particles in calcareous oozes buried approximately $100 \mathrm{~m}$.

Sensitivity. In the case of the DSDP split cores, no accurate assessment of the sensitivity of the sediments, i.e. the ratio of undisturbed to remolded strengths, can be obtained since the amount of sample disturbance is very high. Lee (1973d) obtained a sensitivity factor of about 6 from relatively undisturbed box core samples of pelagic brown clay taken from the Pacific Ocean. As noted earlier, the Pacific brown clays frequently contain high percentages of montmorillonite which is noted for its thixotropic behavior, i.e. after complete remolding, the interparticle cohesive bonds will reestablish themselves with time. Tests by Finn et al (1971) on a very high water content marine clay from the Strait of Georgia off British Columbia indicated an anticipated strength regain of about 150 percent based on initial remolded shear strength.

Silva and Beverly (1974) indicate a sensitivity value of between 8 and 12 for a calcareous ooze obtained by giant piston core from the Mid-Atlantic Ridge. Noorany (1971) indicates sensitivities ranging from 6 to 10 for a calcareous ooze obtained by spade corer in the Pacific Ocean, and Lee (1976) recorded in situ sensitivities of between 5 and 10 for foram ooze in the Western North Atlantic Ocean. If the undisturbed shear strength of the ooze can be attributed to either incipient cementation or residual confining pressure in the sample, then a reduction of strength of this order when remolded can easily be anticipated. 
Triaxial Tests. Very few triaxial compression tests to establish pore pressure response and the internal friction angle of ocean sediments are recorded in the literature. Valent (1974) performed consolidated-undrained triaxial tests on specimens of non-plastic foram ooze from a box core sample obtained from the Caribbean Sea (Venezuela Basin) and recorded effective angles of internal friction, $\phi^{\prime}$, between 33 and 37 degrees. Lee (1976) obtained a $\phi^{\prime}$ value of 32 degrees from triaxial tests on a non-plastic foram ooze obtained by box core from the Western North Atlantic Ocean. These values are less than the 42 degrees obtained from a recompacted, less plastic sample of foram ooze at lower water content tested in the present study (sample 41). Silva and Bever1y (1974), from tests on a "poor quality" core of calcareous ooze (possibly nanno ooze) from the Mid-Atlantic Ridge obtained $\phi^{\prime}$ values between 30 and 31.5 degrees which are less than the 42 degrees obtained from the "undisturbed" samples of nanno ooze from the Mid-Atlantic Ridge tested in the present study.From triaxial tests on calcareous oozes from the Eastern Atlantic Ocean, Demars et al (1976) found that $\phi^{\prime}$ values increased from about 28 degrees to 31 degrees when carbonate content increased from around 25 percent to over 60 percent.

Lee (1973d) performed 5 consolidated-undrained triaxial tests on samples cut from a box core of pelagic clay obtained from the Pacific Ocean and recorded $\phi^{\prime}$ values ranging from 30 to 37 degrees. More recently, Lee (1976) obtained a $\phi^{\prime}$ value of about 27 degrees from triaxial tests on box core samples of pelagic clay from the Western North Atlantic Ocean. Moore (1964) performed a series of 7 multiple-stage consolidated-undrained triaxial tests on samples obtained from the Mohole project, mainly from the Guadalupe site in the Pacific Ocean. The samples were composed chiefly of hemipelagic silty clays obtained at penetrations between 0 and $150 \mathrm{~m}$; the sediments also contained some calcareous skeletal material. $\phi^{\prime}$ angles recorded ranged from 17.5 to 37.5 degrees; these angles generally varied inversely with the sediment plasticity index, as previously noted by Bjerrum and Simons (1961) for normally consolidated clays. The $\phi^{\prime}$ values reported by Lee and Moore are generally higher than the 19 to 22 degree range obtained for remolded terrigenous and hemipelagic clay specimens in the present study, and contrast with $\phi^{\prime}$ of about 20 degrees obtained from numerous tests on undisturbed soft terrigenous clay samples from the continental shelf of the Gulf of Mexico. 
Liquefaction and Cyclic Loading. Under the effects of frequent loading reversal such as can occur rapidly during earthquakes or mechanical vibration, or more slowly due to wave or wind loading, pore pressure buildup may occur In the foundation soils, leading to decreased shear strength, or, where liquefaction occurs, complete loss of strength. It is known that loose, finegrained granular soils are particularly susceptible to liquefaction. Seed and Lee (1966) have concluded from tests on saturated sand that the danger of liquefaction as a result of cyclic loading increases with (1) increased void ratio, (2) lower confining pressure, (3) increasing magnitude of stress or strain, and (4) the number of stress cycles to which the material is subjected. Average water contents and unit weights of the oozes shown on Plates 14 and 15, respectively, suggest that these fine-grained granular materials are in loose condition, the siliceous oozes being loose regardless of penetration and the calcareous oozes being looser nearer the seafloor. We can conclude that these oozes are probably prone to liquefaction, particularly in the case of near-seafloor materials where confining pressures are least. To date, the only cyclic test data available on deep-sea oozes are from triaxial cyclic tests on calcareous ooze from the eastern flank of the Mid-Atlantic Ridge, presented by Silva and Beverly (1974). Their results indicate that liquefaction of the ooze may occur under cyclic loading for stress ratios (i.e. the ratio of half the deviator stress to the consolidation pressure) of about 0.13 for 100 cycles and 0.05 for about 5000 cycles. These values are close to the lower bound of cyclic test results on sand and silty sand reported in the literature. Lee (1973c), from his studies of diatom ooze from the Leg 19 cruise in the North Pacific, concluded that diatom ooze was extremely sensitive to liquefaction.

For clays, loss of strength due to cyclic loading may be in general somewhat less than for loose sands. Lee (1973) suggests that the effect of cyclic loading in clays is very complex and is influenced by a large number of factors. Thiers and Seed (1969) demonstrated that cyclic strength of clays corresponds to cyclic strain and that plastic soils which undergo large strains under fixed stress appear to lose strength faster than stiff soils. Results published to date indicate that the cyclic stress to failure in undisturbed clay samples at about 100 cycles ranges from less than 30 percent to over 60 percent of the static shear strength depending on the type of 
clay. Lee (1973) concludes that more work is required to better understand the strength of clay solls under cyclic loading.

E 1 as tic properties

The elastic properties of deep sea solls are not specifically reported in the 1iterature. Therefore, any assumptions regarding their elastic behavior will be based on the results of the present laboratory tests and general elastic properties of soils.

Poisson's Ratio. For undrained normally consolidated saturated clays, Poisson's ratio is generally assumed to be 0.5 ; for drained, stiff clays, Converse (1962) quotes a range from 0.4 to 0.45 . The range in values for granular materials is wide, and depends on grain size, gradation, particle angularity and density. For lacustrine silts, Zeevaert (1972) indicates values from 0.35 to 0.43 ; for sandy silts, Zeevaert and Harr (1966) both indicate a range from 0.3 to 0.35 . Values quoted for sand range from 0.15 (Harr, coarse sand) to 0.36 (Converse, dense sand).

Modulus of Elasticity. For saturated clays, an established method of expressing the value of modulus of elasticity, $\mathrm{E}$, is by the ratio $\mathrm{E} / \mathrm{c}$, where $c$ is the cohesive shear strength. For each clay type, E/c is considered fairly constant. Matlock (1970) recommends values of $E_{50} / c$ from 50 for soft or remolded clays to 200 for sensitive or brittle clays, where $E_{50}$ is secant modulus at 50 percent peak stress. Hanna and Adams (1968) obtained $\mathrm{E}_{50} / \mathrm{c}$ values averaging about 200 from unconsolidated-undrained triaxial tests on lightly overconsolidated clay, but found $E_{50} / c$ values in the field of over 1000. Recent consolidated-undrained triaxial tests on ten undisturbed samples of soft continental shelf Gulf of Mexico clay yielded $\mathrm{E}_{50} / \mathrm{c}$ values ranging from 100 to 500 with an average value of about 280; these values are of the same order as the $\mathrm{E}_{50} / \mathrm{c}$ (or $2 \mathrm{E}_{50} /\left(\sigma_{1}-\sigma_{3}\right)$ ) values shown on Plate 13 for tests on remolded clays for the present study; this agreement is perhaps surprising since remolded samples give, in general, significantly lower $\mathrm{E}_{50} / \mathrm{c}$ values than undisturbed samples.

Modulus of elasticity values for granular materials range widely, being a function of grain size, gradation, density, particle angularity and confining pressure. Minimum values are obtained from tests on fine, loose, breakable, angular materials at low confining pressures, and conversely, maximum values are produced from coarse, dense, hard, rounded materials at 
high confining pressures. Lambe (1969) indicates that, for initial loading, sediments with angular, breakable particles may have $\mathrm{E}$ values of only one quarter to one third of those with hard, rounded particles. This is of particular relevance in the context of skeletal debris in the deep-sea oozes. Consolidation Characteristics

Knowledge of the consolidation characteristics of sediments is valuable for an understanding of the depositional processes and stress history of the sediment and for predicting the settlement of engineering structures on the sediment. Consolidation of deep-sea soils has been investigated in the laboratory by applying stress to a sample and recording subsequent deformation, and in the field by comparing in situ void ratios with existing overburden pressures.

Depositional Characteristics. The most common method of presenting the results of laboratory consolidation tests is by plotting void ratio versus the logarithm of applied pressure. From this plot, the maximum past pressure on the sediment in situ may be calculated. If the maximum past pressure is less than the present effective overburden pressure, the sediment is termed underconsolidated. Where deposition of impermeable material is extremely rapid, e.g. up to $1 \mathrm{ft}$ per year in the Mississippi Delta, excess pore pressures are generated within the material and the effective overburden pressure on the sediment will be less than under equilbrium conditions, i.e. underconsolidation. Due to the extremely slow rate of accumulation of ocean sediments, (as slow as $0.2 \mathrm{~mm}$ per 1000 years in some regions according to Griffin et al, 1968), underconsolidation will generally not occur. The effects of underconsolidation in the consolidation test are very similar to the effects of sample disturbance; underconsolidation noted by Trabant et al (1974) from tests on sediments from the DSDP Leg 31 cruise in the West Philippine Basin are more probably attributable to the effects of sample disturbance.

Where maximum past pressure is similar to the present effective overburden pressure, the sediment is termed normally consolidated. Deposited sediments which have been allowed to reach an equilibrium state with no dessication, removal of overlying sediments, or chemical bonding are normally consolidated. Lee $(1973 \mathrm{~b})$ found the samples of diatomaceous silty clay and 
diatom ooze, obtained from different penetrations at six sites during the DSDP Leg 19 cruise in the Bering Sea and North Pacific, to be normally consolidated. Where maximum past pressure is greater than the present effective overburden pressure, the sediment is termed overconsolidated. Common examples of overconsolidation are where the overlying material has been removed by erosion or where dessication of the material has occurred. Many researchers have noted overconsolidation effects in deep sea sediments at various penetrations, including seafloor sediments. Keller and Bennett (1973) noted overconsolidation in zeolitic clays and nanno oozes on the DSDP Leg 16 cruise; Hamilton (1964) observed overconsolidation in pelagic and hemipelagic clays from the Mohole project and Lee (1973d) observed overconsolidation in a seafloor box core sample of pelagic clay from the Pacific Ocean. Since deepsea sediments have not in general been stripped of overburden or dessicated, this observed overconsolidation has been termed "apparent overconsolidation" and has been attributed to interparticle bonding with age, whether as a result of reorientation of water molecules in the vicinity of contact points (Leonards and Altschaeffl, 1964) or chemical cementation (Hamilton, 1964).

Engineering Characteristics. The compression index $C_{c}$, which is the slope of the void ratio versus logarithm of applied pressure curve in the consolidation test, is a measure of the compressibility of a sediment. For terrigenous clay, various correlations have been suggested between $C_{c}$ and the liquid limit of the clay (Sherman and Hadjidakis, 1962, or Terzaghi and Peck, 1967). Valent (1974) concluded that established relationships between $\mathrm{C}_{c}$, void ratio, water content and plasticity do not apply to calcareous ooze since much of the water in these materials is entrapped within the hollow tests and does not substantially affect the soil compressibility. Valent's conclusions should be equally applicable to siliceous oozes. Recently, Demars et al (1976) proposed a relationship between $C_{c}$ and plasticity index for calcareous oozes, based on the results of over 30 consolidation tests. Lee (1973c) has proposed a correlation between $C_{c}$, water content and void ratio of diatom oozes, but notes that this correlation is probably only valid for siliceous soils. Values from the literature of $c_{c}$ for samples of various sediments are presented on Plate 19 along with the liquid limit and initial vold ratio values for the samples. 
Two consolidation characteristics, namely "apparent overconsolidation" and grain crushing, are mostly unique to ocean sediments and may affect their settlement behavior under imposed loading. If the sediment has "apparent overconsolidation", as has been observed in some calcareous oozes and in hemipelagic and pelagic clays, it will be almost incompressible up to the apparent maximum past pressure. However, beyond this, the material becomes very compressible due to the high initial void ratio inherent in most ocean sediments. Where structures are supported by "apparently overconsolidated" materials, 1ittle settlement or movement may occur up to the apparent maximum past consolidation pressure; if this pressure is exceeded, extensive settlement may result.

Calcareous and diatom ooze grains are generally hollow and may be liable to crushing under imposed loading. Noorany (1971) noted from his foram ooze consolidation tests that re-orientation and crushing of the individual grains appeared to continue throughout the tests. Lee (1973c) indicated some degree of skeletal grain crushing in tests on diatom ooze. Valent (1974) found that crushing of foram tests did not occur during consolidation tests on undisturbed samples, even under high loads; however, when much of the finer material was removed, grain crushing did occur. Valent suggested that the fine-grained material helps distribute the loading to prevent grain crushing. Grain crushing of oozes involves not only some collapse of the sediment structure but also the release of water from inside the grains; this water may help lubricate the exterior surface of the remaining grains and cause even greater compression and resulting structural settlement.

\section{SOIL PARAMETERS} SUMMARY AND RECOMMENDATIONS

Summaries of the test results of ocean sediments presented and discussed in previous chapters of this report are presented on Plate 20 for calcareous ooze, Plate 21 for siliceous ooze, and Plate 22 for clay materials. Included on these plates are remarks concerning the parameter values and also references to the plate or literature reference where these results are presented or discussed in more detail. It is important that the results summarized on Plates 20 through 22 be viewed in the context of the discussion presented in the text. 
It is evident from the results on Plates 20 through 22 that the best documented parameters are those pertaining to the classification properties, namely water content, specific gravity, unit weight, grain size, and, to a lesser extent, Atterberg limits. Since tests to determine these properties can be performed successfully on completely remolded samples, they have frequently been included as a routine part of many ocean sediment investigations. Parameters which reflect the in situ structure of the sediment, namely strength, elasticity, and consolidation parameters, require undisturbed samples to provide generally meaningful laboratory test results and are therefore less documented; in fact, as far as ocean sediments are concerned, parameters such as Poisson's ratio, elastic modulus or cyclic strength have little or no documentation.

$\underline{\text { Recommended Design Parameter Values }}$

Plates 20 through 22 summarize the maximum, minimum and average parameter values available to date from a variety of ocean sediment studies, including the present study. Some of these values may be used, as recommended below, in engineering analyses, if no other source of information on parameters is available for the material under study. These values should not be used without a clear understanding of the underlying assumptions and value variations discussed in previous chapters.

Average values presented represent averages derived from a substantial quantity of data and may be used as a best estimate for analysis; however, minimum and maximum values should be carefully considered when using the average values, since these represent the possible range of values experienced. In the case of water content, standard deviations of the averages are presented on Plate 14. For specific gravity, the range is small enough to justify, in general, an average value to be assumed. This argument likewise applies to the unit weight of siliceous ooze, and, to a lesser extent, to the unit weights of calcareous ooze and clay.

Where the "average" column is blank but minimum and maximum values are presented, e.g. grain size of calcareous ooze, we consider that the actual value at a particular site, although it will lie within the given range, will be primarily a function of depositional conditions at that site, e.g. location and water depth for grain size or clay content for Atterberg limits, and no assumed average value can be justified. In these cases, the minimum and 
maximum values can be used to define the range for use in analysis. Of course, values outside the given range may occur, but we consider that this range includes the vast majority of anticipated values.

Where the "average" column contains the words "limited data", the minimum and maximum values given represent the range of values derived from a limited number of tests and cannot be used to define the complete range of values anticipated; they may be used where only an approximate range of values is required. Values which appear in the "very limited data" column should be used only as an approximate guideline and not for design purposes.

For $\phi^{\prime}$ values, an arrow appears in the "average" column to emphasize that, for design purposes, the limiting values should be as stated in the "remarks" column. It has been our experience that $\phi$ ' values for design of structures on loose granular materials consisting of particles mainly in the silt and sandy silt range should not be more than 20 and 25 degrees, respectively. Since the commonly used bearing capacity theorems (e.g. Terzaghi and Peck, 1967, Meyerhof, 1951) are based on the assumption of rigid-plastic, incompressible materials, in cases where materials are loose and compressible the mode of fallure is altered and the bearing capacity is reduced; the lower design $\phi^{\prime}$ values take account of this reduction.

\section{RECOMMENDATIONS FOR FUTURE WORK}

Throughout the course of this investigation, we have noted the surprisingly small quantity of engineering solls data which has been generated from so many deep sea cores. The Deep Sea Drilling Project would appear to be a unique opportunity to investigate the engineering characteristics of seafloor and sub-seafloor soils on a worldwide basis. To this end, therefore, we present recommendations for obtaining more complete and more accurate engineering soils data from this project in the future. The recommendations fall into four categories, namely, geotechnical engineering personnel, in situ solls testing, sample retrieval and handling, and laboratory testing. 
Geotechnical Engineering Personne1

On the few previous DSDP cruises where geotechnical engineers have made up part of the scientific body, meaningful engineering soils data have been developed from tests run on board and, at a later date, on shore. We recommend that a geotechnical engineer should accompany each future cruise of DSDP to promote collection and development of relevant engineering soils data. The geotechnical expertise provided would also be valuable for assessment of seafloor conditions for the re-entry cone and attached casing.

In S I t u T e s t ing

Some degree of disturbance of seafloor and sub-seafloor cores recovered from deep water locations is inevitable in the present state of the sampling art. The most accurate means of measuring in situ properties, therefore, is by in situ testing. This type of testing is most valuable in the seafloor and near seafloor soils, where, in general, the sediments are softest and most liable to sampling disturbance and where knowledge of the in situ strength is essential for design of temporary or permanent seafloor structures.

For the past several years, McClelland Engineers have successfully operated a remote wireline-operated vane device in water depths to $300 \mathrm{~m}$ and penetrations down to $150 \mathrm{~m}$ below the Gulf of Mexico seafloor. This vane measures the in situ strength of very soft to very stiff cohesive soils. McClelland Engineers have also recently completed development of a cone penetrometer which, in its present form, can operate in $250 \mathrm{~m}$ of water to provide a continuous strength profile through both granular and cohesive sediments extending several hundred meters below the seafloor; this cone can also operate in over $1000 \mathrm{~m}$ of water to provide near seafloor strength profiles. We believe that both vane and cone-type equipment can be modified to operate successfully in very deep water and we recommend that development of this type of in situ measuring equipment should be pursued. The use of a deep sea cone and/or vane in combination with the present coring operation would provide valuable data for foundation design of future seafloor structures in addition to allowing for a more accurate prediction of penetration of the reentry cone and conductor pipes used in DSDP. 
Sample Retrieval and Handling

Due to the physical configuration of the coring equipment at present in use on the "Glomar Challenger", the resulting cores are considerably disturbed. This disturbance may be minimized by extending the double-tube core barrel beyond the bit, if possible by as much as two times the bit diameter, and by providing the core-barrel with the largest possible inside diameter. We understand that DSDP personnel are at present in the process of developing this type of system.

After the core barrel has been unlatched, retrieval to deck should be performed as smoothly as possible. Once on deck, the barrel must be handled with extreme care - any sudden contact with the deck may cause densification of the core, especially in the case of high water content material.

As pointed out in previous sections of this report, once the core has been split longitudinally, any soils tests that measure properties which are functions of the soil structure are virtually precluded. We recommend that small portions of selected cores remain unsplit, in order that more meaningful engineering soils data may be generated. These unsplit portions should be carefully sealed and stored to prevent water content and structure changes. L a boratory testing

We recommend that:

(1) Engineering soils tests on board should be performed in accordance with ASTM standards by experienced personnel using well-maintained equipment. (2) On board water content determination should be performed on specimens from each core; in accordance with ASTM D 2216-71, at least $10 \mathrm{~g}$ of material should be used in the case of clay and silt-sized sediments.

(3) Liquid and plastic limits should be determined on board to aid engineering classification.

(4) Miniature vane or Torvane shear strength testing should be performed routinely on board for cohesive or partly cohesive sediments. Accurate water content determination should be made on specimens so tested.

(5) On board unit weight determination should be made by accurately weighing and measuring homogeneous specimens; very small specimens should be avoided. Care must be taken to ensure that the geometry of the specimen container is regular and that no air voids exist within the specimen. 
(6) The carefully sealed and stored unsplit portions of the core should be tested on land to provide appropriate engineering parameters for the particular site and type of material involved. These tests would normally require more sophisticated apparatus than carried on board ship, and would determine parameters associated with soll structure. These tests might include consolidation, static and cyclic triaxial, static and cyclic simple shear, and permeability determination. 
ILIUSTRATIONS 




\begin{tabular}{|c|c|c|c|c|c|c|c|c|c|c|c|c|c|c|c|c|}
\hline & & & & sul & AMARY & OF SAMPL & E DESCRIP & TIONS AND & TEST RE & SULTS & & & Test $\mathrm{Re}$ & Cesults & & \\
\hline $\begin{array}{l}\text { Somple } \\
\text { No. }\end{array}$ & Location & Leg & Site & Core & Section & $\begin{array}{c}\text { Interval } \\
\mathrm{cm}\end{array}$ & $\begin{array}{c}\text { Water } \\
\text { Depth, m. }\end{array}$ & $\begin{array}{c}\text { Penetration, } \\
\text { m. }\end{array}$ & $\begin{array}{c}\text { Sample } \\
\text { Type }\end{array}$ & Sample General Description & 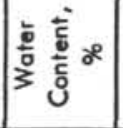 & $\begin{array}{l}\frac{D}{3} \overline{\bar{E}} \\
\frac{\bar{g}}{\mathrm{E}}\end{array}$ & $\frac{u}{\frac{a}{a}}$ & 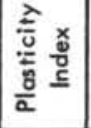 & 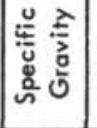 & 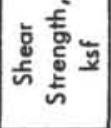 \\
\hline 52 & & 24 & 234 & 1 & 5 & 125 to 140 & 4721 & 7 & bag $100 \mathrm{~g}$ & Nanno ooze & 123 & 146 & 55 & 91 & 2.60 & 0.3 \\
\hline 53 & & 24 & 234 & 1 & 5 & 140 to 142 & 4721 & 7 & vial $10 \mathrm{~g}$ & Nanno ooze & 121 & & & & & \\
\hline 54 & $4.48^{\circ} \mathrm{N}$ & 24 & 234 & 2 & 5 & 11 to 13 & 4721 & 16 & vial $10 \mathrm{~g}$ & Clay & 121 & & & & & 0.5 \\
\hline 55 & $51.22^{\circ} \mathrm{E}$ & 24 & 234 & 3 & 5 & 110 to 125 & 4721 & 26 & bag $100 \mathrm{~g}$ & Clay & 122 & 170 & 47 & 123 & 2.68 & 0.5 \\
\hline 56 & $\begin{array}{l}\text { Indian } \\
\text { Ocean, off }\end{array}$ & 24 & 234 & 3 & 5 & 125 to 127 & 4721 & 26 & vial $10 \mathrm{~g}$ & Clay & 117 & & & & & \\
\hline 57 & Somali & 24 & 234 & 4 & 5 & 115 to 117 & 4721 & 36 & vial $10 \mathrm{~g}$ & Clay & 108 & & & & & 0.6 \\
\hline 58 & & 24 & 234 & 7 & 5 & 10 to 25 & 4721 & 120 & bag $100 \mathrm{~g}$ & Clay & 80 & 168 & 45 & 123 & & \\
\hline 59 & & 24 & 234 & 7 & 5 & 25 to 27 & 4721 & 120 & vial $10 \mathrm{~g}$ & Clay & 78 & & & & & \\
\hline 60 & & 31 & 302 & 2 & 5 & 46 to 48 & 2399 & 26 & vial $10 \mathrm{~g}$ & Diatom rich silty cloy & 112 & & & & & 0.2 \\
\hline 61 & & 31 & 302 & 3 & 5 & 100 to 115 & 2399 & 45 & bag $100 \mathrm{~g}$ & Silty clay & 96 & 136 & 49 & 87 & & 1.0 \\
\hline 62 & & 31 & 302 & 3 & 5 & 115 to 117 & 2399 & 45 & vial $10 \mathrm{~g}$ & Silty clay & 101 & & & & & \\
\hline 63 & & 31 & 302 & 4 & 5 & 75 to 77 & 2399 & 64 & vial $10 \mathrm{~g}$ & Silty clay & 96 & & & & & 1.2 \\
\hline 64 & & 31 & 302 & 5 & 5 & 120 to 122 & 2399 & 83 & vial $10 \mathrm{~g}$ & Diatom ooze & 106 & & & & & 1.1 \\
\hline 65 & $40.34^{\circ} \mathrm{N}$ & 31 & 302 & 7 & 3 & 100 to 115 & 2399 & 118 & bog $100 \mathrm{~g}$ & Diatom ooze & & & & & 2.38 & \\
\hline 66 & $136.90^{\circ} \mathrm{E}$ & 31 & 302 & 7 & 3 & 115 to 117 & 2399 & 118 & vial $10 \mathrm{~g}$ & Diatom ooze & 145 & & & & & \\
\hline 67 & Sea of Japan & 31 & 302 & 8 & 5 & 100 to 102 & 2399 & 140 & vial $10 \mathrm{~g}$ & Diatom ooze & 168 & & & & & \\
\hline 68 & & 31 & 302 & 9 & 2 & 120 to 135 & 2399 & 155 & bog $100 \mathrm{~g}$ & Diatom ooze & & & & & 2.30 & \\
\hline 69 & & 31 & 302 & 9 & 2 & 135 to 137 & 2399 & 155 & vial $10 \mathrm{~g}$ & Diatom ooze & & & & & & \\
\hline 70 & & 31 & 302 & 10 & 5 & 107 to 109 & 2399 & 178 & vial $10 \mathrm{~g}$ & Diatom ooze & 153 & & & & & \\
\hline 71 & & 31 & 302 & 11 & 4 & 100 to 115 & 2399 & 196 & bag $100 \mathrm{~g}$ & Diatomaceous ooze & 164 & 185 & 124 & 61 & & \\
\hline 72 & & 31 & 302 & 11 & 4 & 120 to 122 & 2399 & 196 & vial $10 \mathrm{~g}$ & Diatomaceous ooze & 166 & & & & & \\
\hline 73 & & Wood & to Hole & Core & 5 & 22 to 30 & 4431 & 0.3 & tube $140 \mathrm{~g}$ & Clay rich nanno ooze & 87 & & & & & \\
\hline 74 & & Ship: & Atlor & ntis 2 & 4 & 176 to 184 & 4431 & 1.8 & tube $140 \mathrm{~g}$ & Clay rich nanno ooze & 60 & & & & & \\
\hline 75 & $\begin{array}{l}22.98^{\circ} \mathrm{N} \text {, } \\
43.51^{\circ} \mathrm{W} \text {, }\end{array}$ & $\begin{array}{l}\text { Cru } \\
\text { Leg }\end{array}$ & $\begin{array}{l}\text { jise: } \\
\text { : }\end{array}$ & 92 & 3 & 184 to 188 & 4431 & 1.8 & bag $250 \mathrm{~g}$ & Clay rich nanno ooze & 60 & 59 & 43 & 16 & & \\
\hline 76 & Mid-Atlantic & Stat & tion: 2 & 27 & 3 & 329 to 337 & 4431 & 3.3 & tube $140 \mathrm{~g}$ & Clay rich nanno ooze & & & & & & \\
\hline 77 & Ridge & Cor & & 7 PC & 3 & 333 to 337 & 4431 & 3.4 & bag $250 g$ & Clay rich nanno ooze & 63 & 64 & 38 & 26 & & \\
\hline 78 & & & & & 2 & 483 to 491 & 4431 & 4.9 & tube $140 \mathrm{~g}$ & Clay rich nanno ooze & 57 & & & & & \\
\hline 79 & & & & & 1 & 628 to 636 & 4431 & 6.3 & tube $140 \mathrm{~g}$ & Clay rich nanno ooze & & & & & & \\
\hline
\end{tabular}




\begin{tabular}{|c|c|c|c|c|c|}
\hline \multirow{2}{*}{$\begin{array}{c}\text { Sediment } \\
\text { Type }\end{array}$} & \multirow{2}{*}{$\begin{array}{c}\text { Number } \\
\text { of } \\
\text { Tests }\end{array}$} & \multicolumn{2}{|c|}{ Water Content, Percent } & \multicolumn{2}{c|}{$\begin{array}{c}\text { Average } \\
\text { Penetration, } \\
\text { m. }\end{array}$} \\
\cline { 3 - 5 } & 22 & 37 & 129 & 75 & 54 \\
\hline \hline Calcareous Ooze & 22 & 105 & 261 & 164 & 114 \\
Siliceous Ooze & 21 & 43 & 122 & 85 & 54 \\
Clay & 4 & 65 & 102 & 82 & 57 \\
Ash & 22 & Max. & Ave. & \\
\hline
\end{tabular}

SUMMARY OF WATER CONTENT VALUES

FROM PRESENT STUDY 



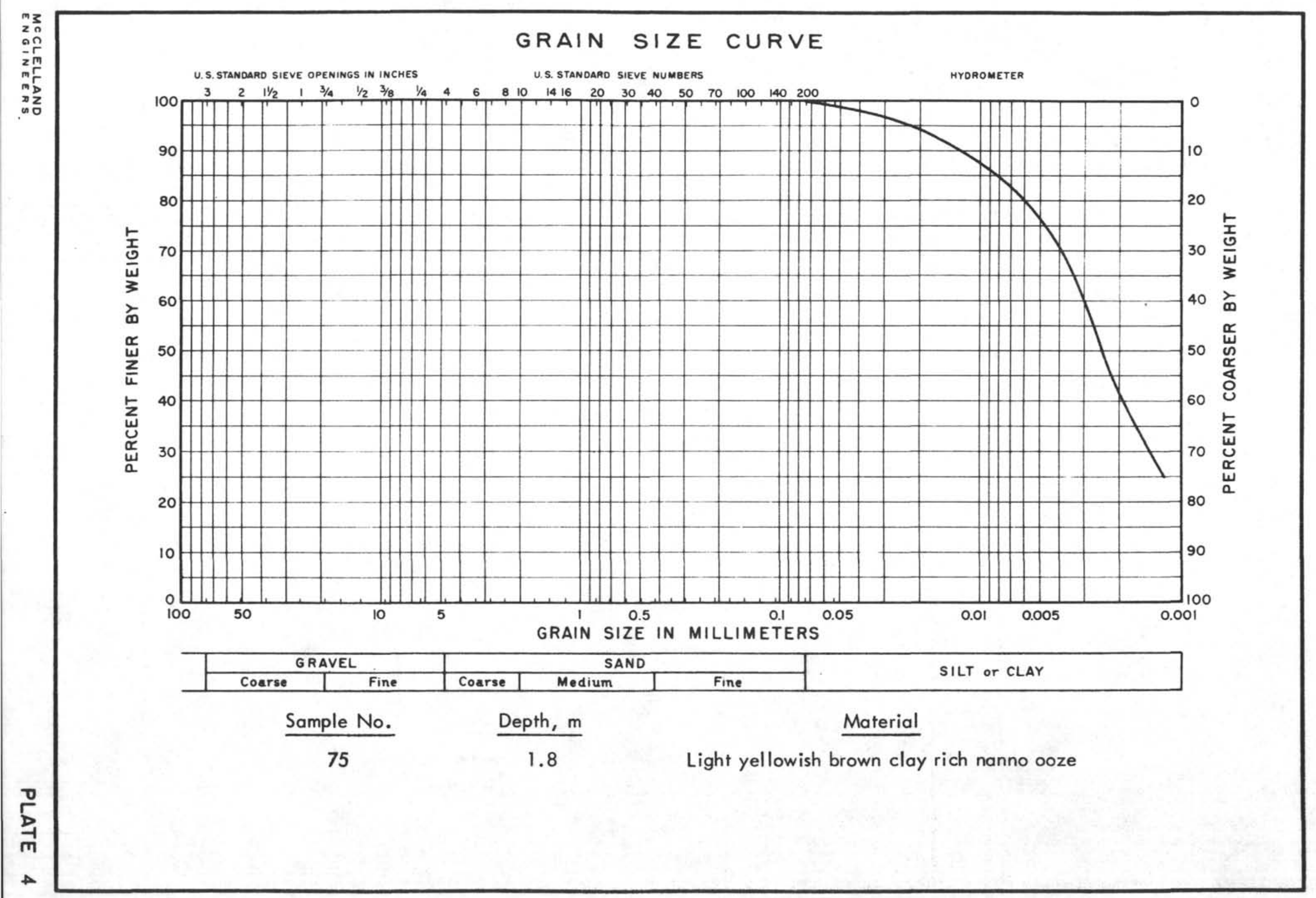




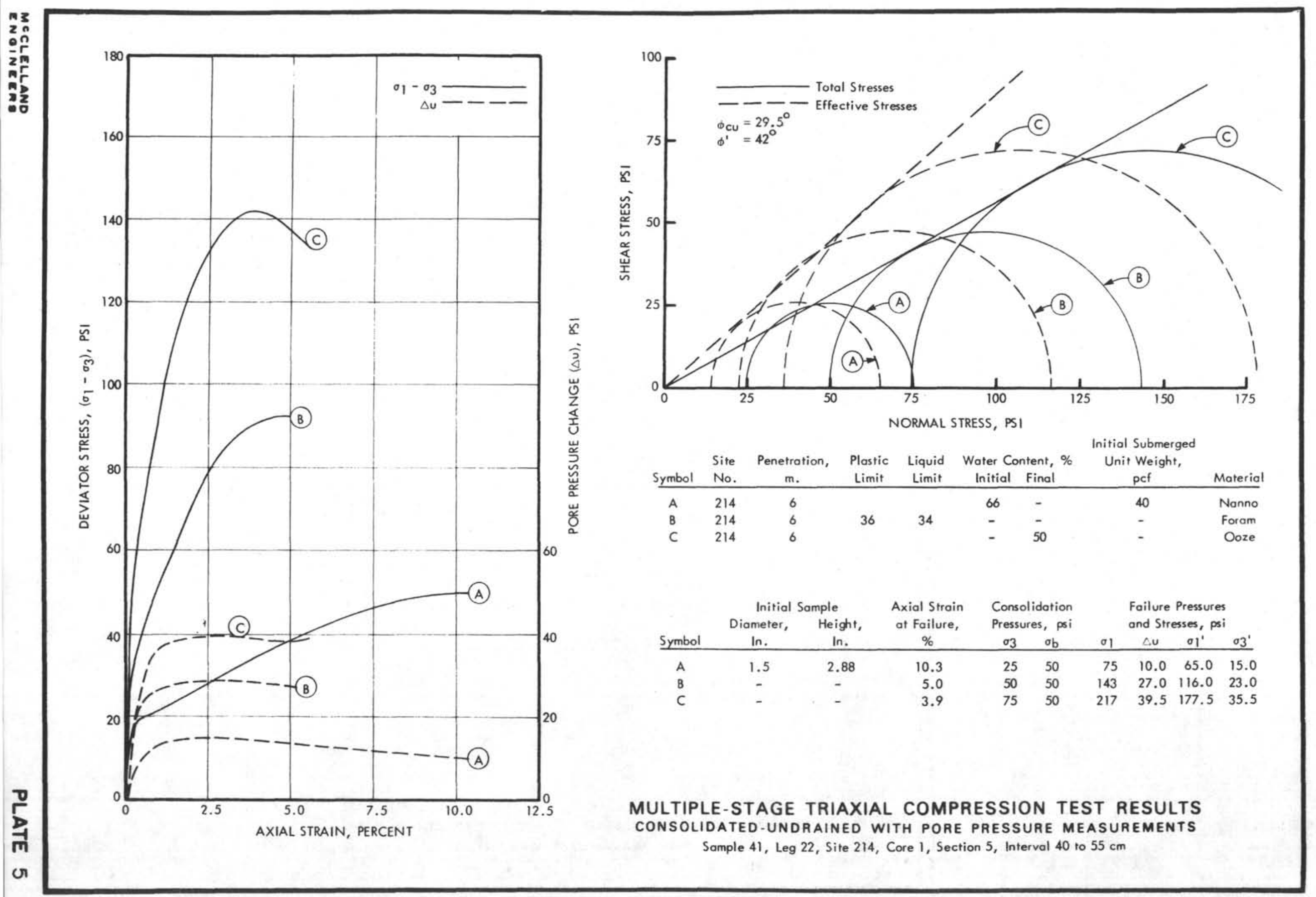



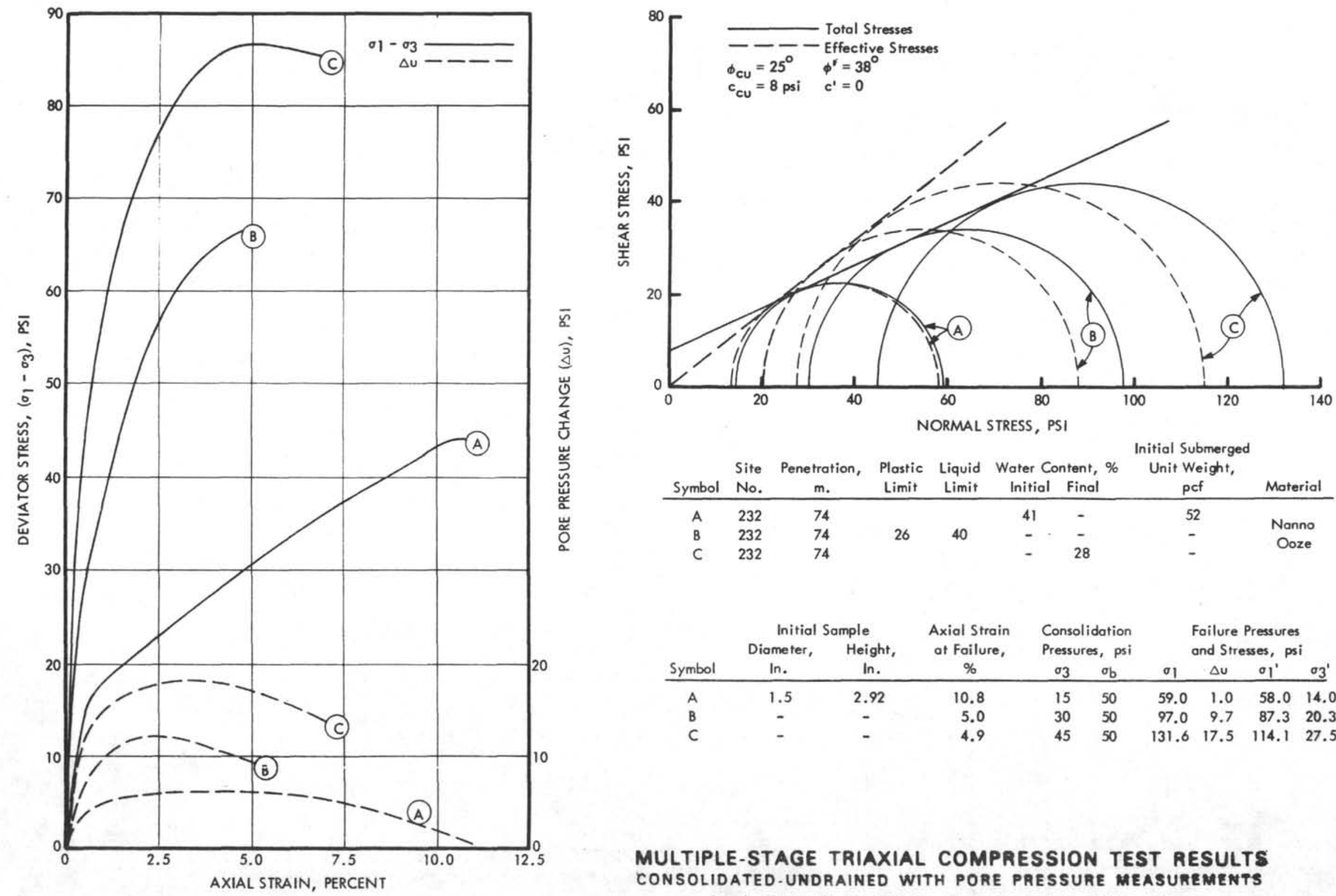

\begin{tabular}{|c|c|c|c|c|c|c|c|c|c|}
\hline \multirow[b]{3}{*}{ Symbol } & \multicolumn{2}{|c|}{ Initial Sample } & \multirow{3}{*}{$\begin{array}{c}\text { Axial Strain } \\
\text { of Failure, } \\
\%\end{array}$} & \multirow{2}{*}{\multicolumn{2}{|c|}{$\begin{array}{l}\text { Consolidation } \\
\text { Pressures, psi }\end{array}$}} & \multirow{2}{*}{\multicolumn{4}{|c|}{$\begin{array}{l}\text { Failure Pressures } \\
\text { and Stresses, psi }\end{array}$}} \\
\hline & Diameter, & Height, & & & & & & & \\
\hline & In. & In. & & $\sigma_{3}$ & $\sigma_{b}$ & $\sigma_{1}$ & $\Delta u$ & $0^{\prime}$ & $\sigma_{3}^{\prime}$ \\
\hline A & 1.5 & 2.92 & 10.8 & 15 & 50 & 59.0 & 1.0 & 58.0 & 14.0 \\
\hline B & - & - & 5.0 & 30 & 50 & 97.0 & 9.7 & 87.3 & 20.3 \\
\hline C & - & - & 4.9 & 45 & 50 & 131.6 & 17.5 & 114.1 & 27.5 \\
\hline
\end{tabular}




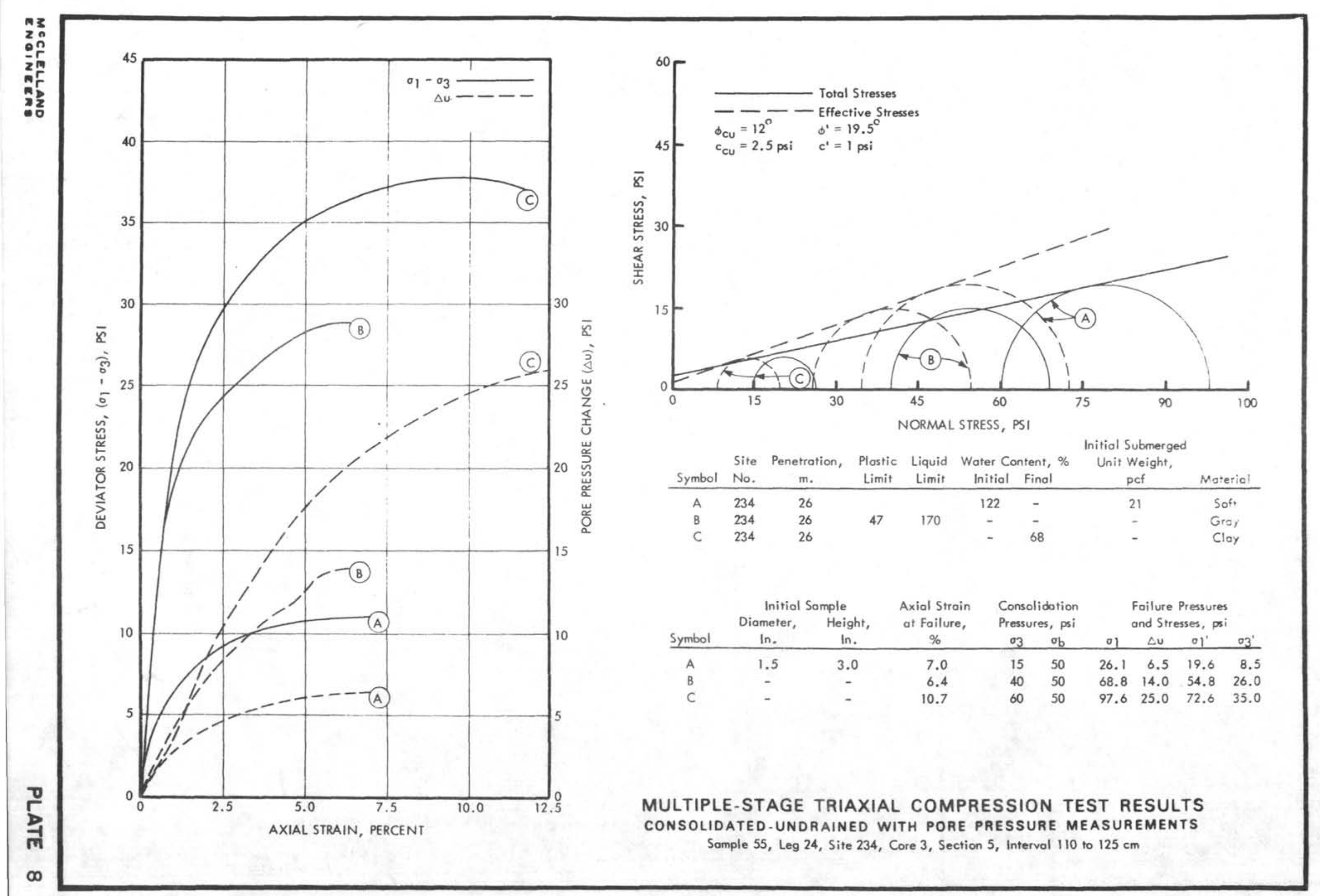




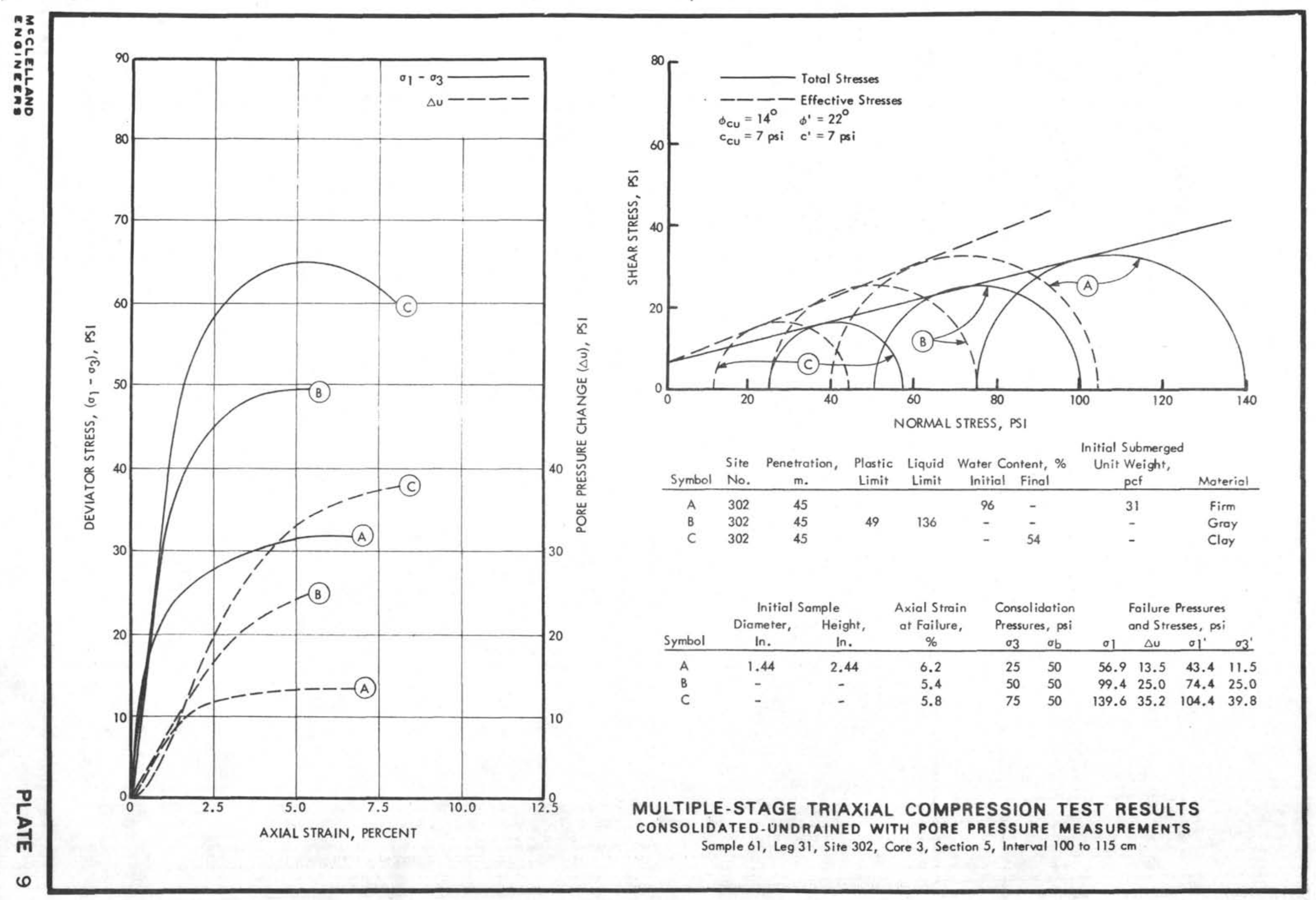




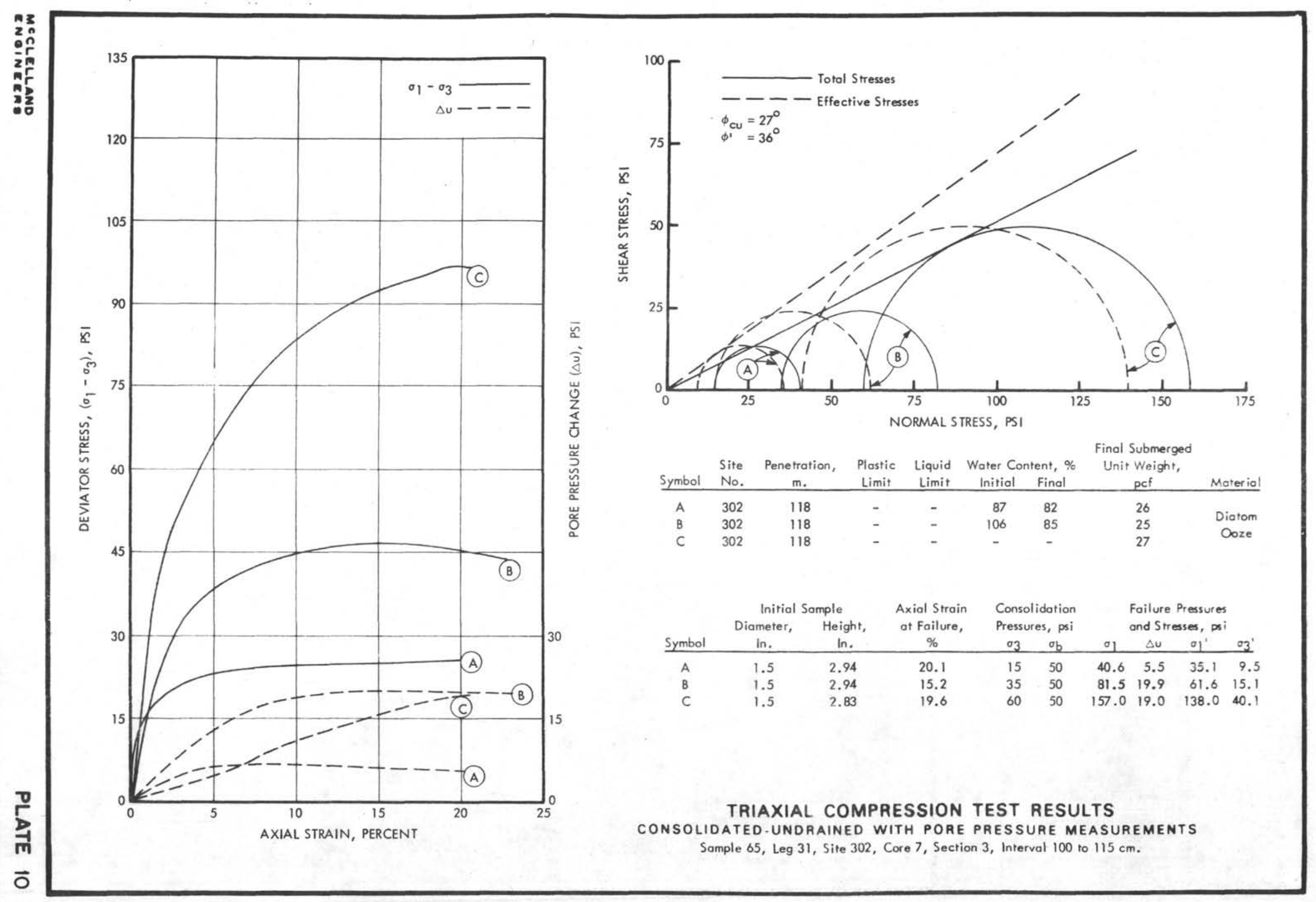


Shear Strength, ksf

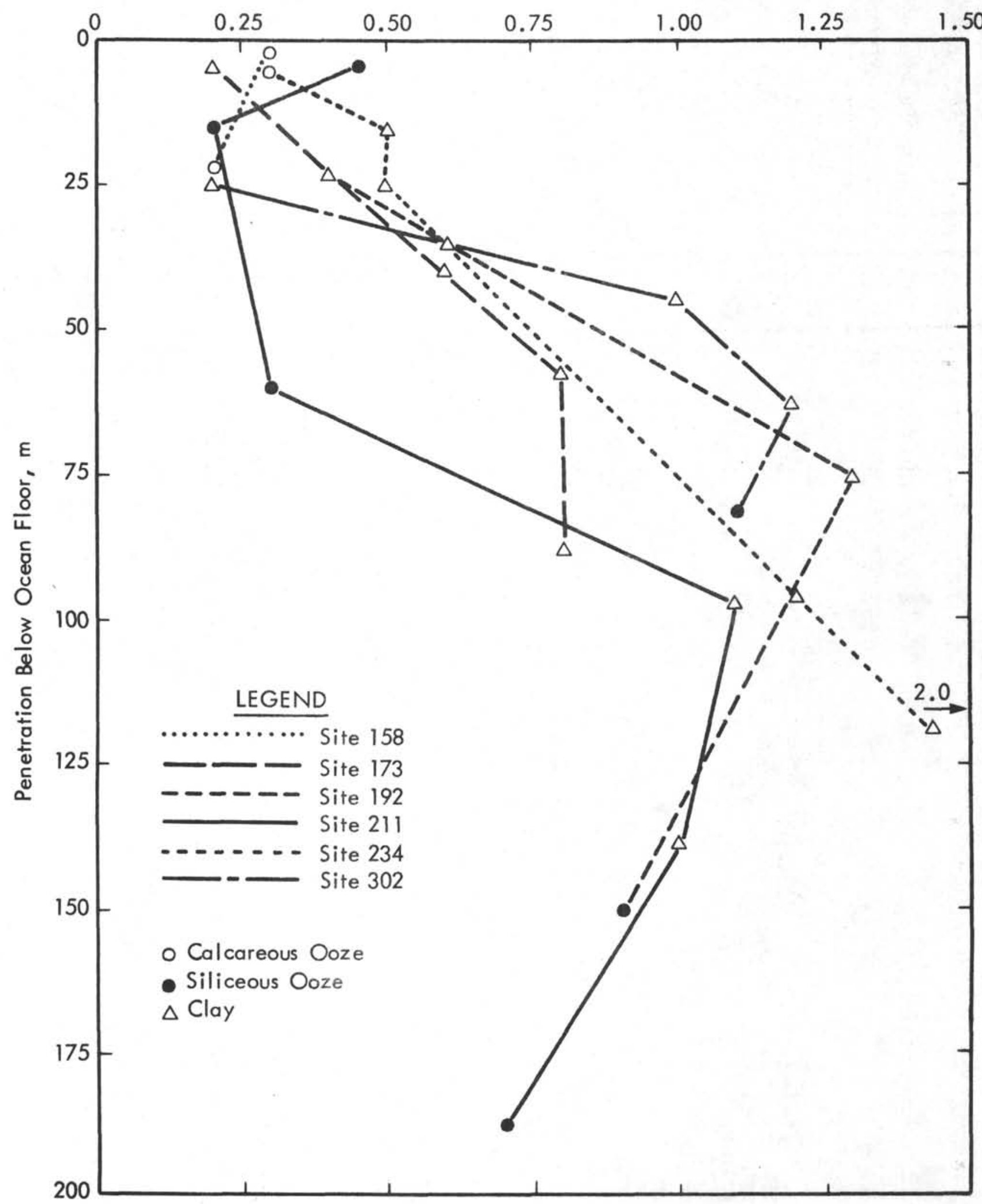

TORVANE STRENGTH TEST RESULTS ON COHESIVE MATERIALS 


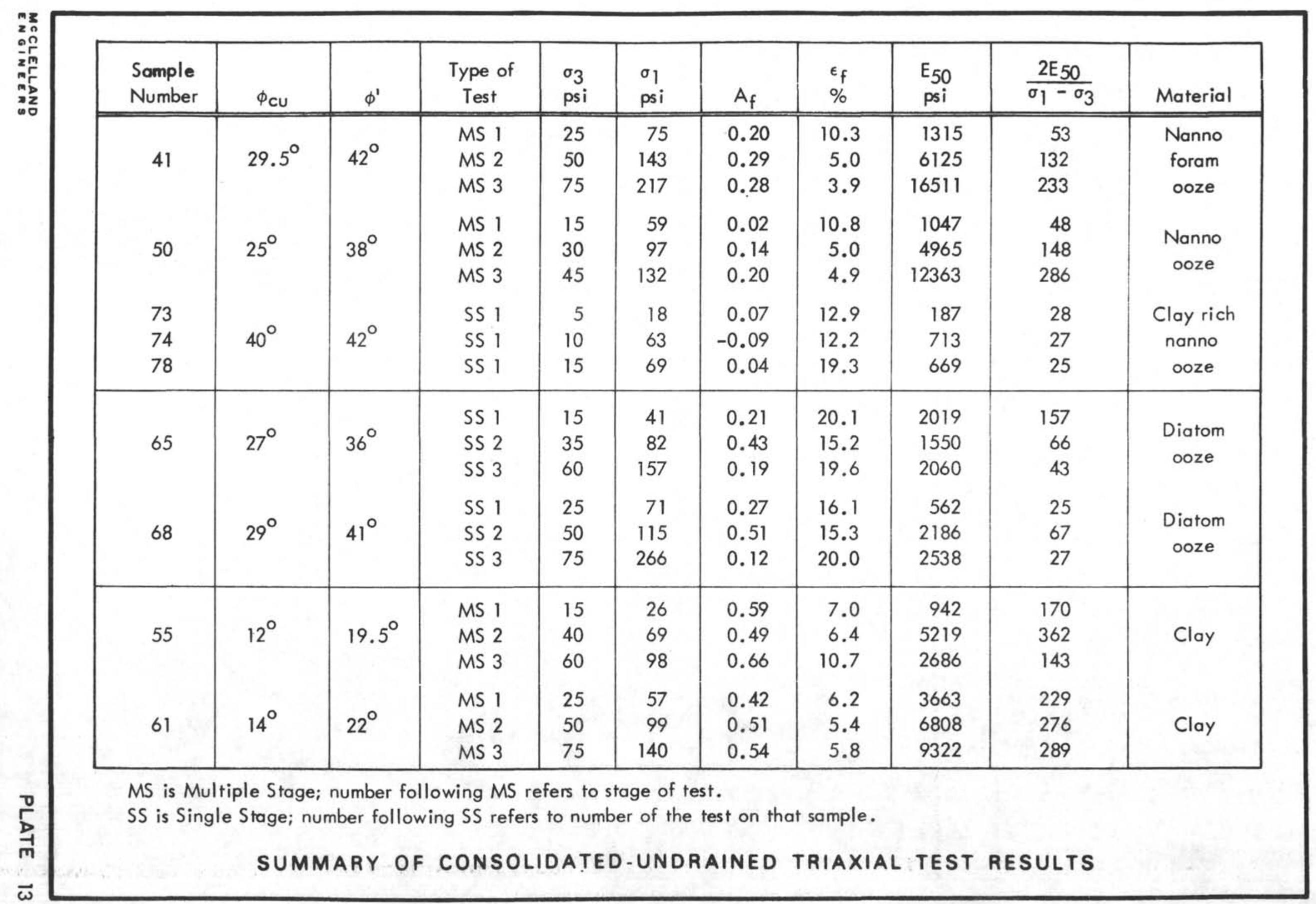





\begin{tabular}{|c|c|c|c|c|}
\hline \multirow{2}{*}{$\begin{array}{l}\text { Sediment } \\
\text { Type }\end{array}$} & \multirow{2}{*}{$\begin{array}{c}\text { Number } \\
\text { of } \\
\text { Samples }\end{array}$} & \multicolumn{3}{|c|}{ Average Particle Size Distribution, Percent } \\
\hline & & $\begin{array}{c}\text { Sand Size } \\
(>0.074 \mathrm{~mm})\end{array}$ & $\begin{array}{c}\text { Silt Size } \\
(0.004 \text { to } 0.074 \mathrm{~mm})\end{array}$ & $\begin{array}{c}\text { Clay Size } \\
(<0.004 \mathrm{~mm})\end{array}$ \\
\hline $\begin{array}{l}\text { Calcareous Ooze } \\
\text { (Nanno-Foram) }\end{array}$ & 6 & 21 & 47 & 32 \\
\hline $\begin{array}{l}\text { Siliceous Ooze } \\
\text { (Diatom) }\end{array}$ & 11 & 2 & 44 & 54 \\
\hline Clay & 11 & 2 & 36 & 62 \\
\hline Ash & 2 & 48 & 38 & 14 \\
\hline
\end{tabular}




\begin{tabular}{|l|c|c|c|c|c|}
\hline \multicolumn{1}{|c|}{ Location } & $\begin{array}{c}\text { Number of } \\
\text { Samples }\end{array}$ & $\begin{array}{c}\text { Chlorite } \\
(\%)\end{array}$ & $\begin{array}{c}\text { Montmorillonite } \\
(\%)\end{array}$ & $\begin{array}{c}\text { Illite } \\
(\%)\end{array}$ & $\begin{array}{c}\text { Kaolinite } \\
(\%)\end{array}$ \\
\hline \hline North Atlantic & $202-206$ & 10 & 16 & 55 & 20 \\
\hline South Atlantic & $196-214$ & 11 & 26 & 47 & 17 \\
\hline North Pacific & 170 & 18 & 35 & 40 & 8 \\
\hline South Pacific & 140 & 13 & 53 & 26 & 8 \\
\hline Indian & $127-129$ & 12 & 41 & 33 & 17 \\
\hline
\end{tabular}

DISTRIBUTION OF CLAY MINERALS

IN OCEAN FLOOR SEDIMENTS

(Griffin et al, 1968) 
Shear Strength, ksf

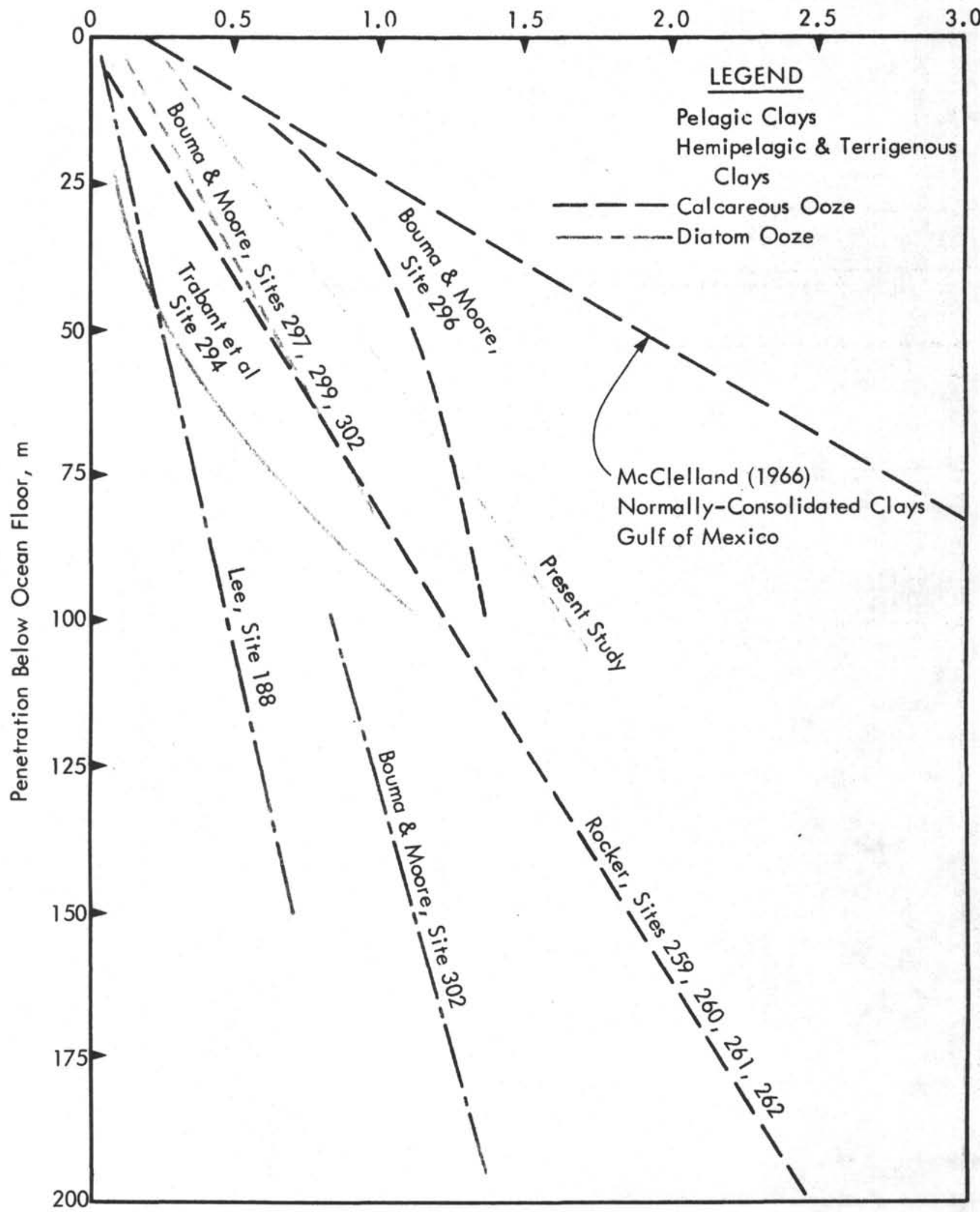




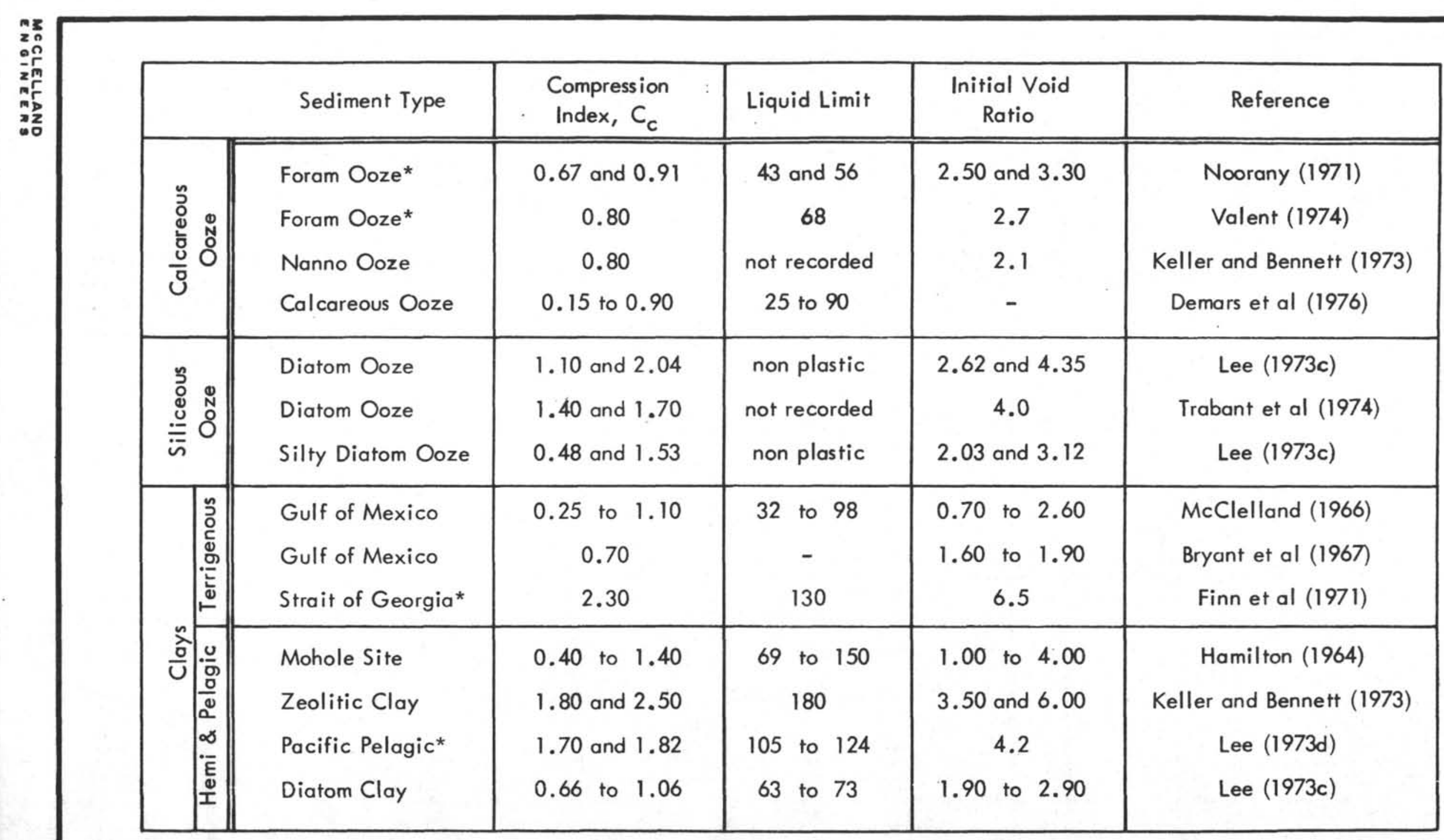

*Seafloor Samples 


\begin{tabular}{|c|c|c|c|c|c|c|}
\hline \multirow{2}{*}{ Porameter } & \multicolumn{4}{|c|}{$\begin{array}{l}\text { All Penetrations } \\
\text { (Seafloor) } \\
{[180 \text { meters }]}\end{array}$} & \multirow{2}{*}{ Remarks } & \multirow{2}{*}{$\begin{array}{c}\text { Plate } \\
\text { or } \\
\text { Reference }\end{array}$} \\
\hline & $\begin{array}{c}\text { Limited } \\
\text { Data }\end{array}$ & Min. & Max. & Ave. & & \\
\hline Water Content, percent & & 33 & 189 & $\begin{array}{c}66 \\
(79) \\
{[51]}\end{array}$ & $\begin{array}{l}\text { DSDP values, } 0 \text { to } 200 \mathrm{~m} \text {. } \\
\text { Decrease of about } 1.65 \% \\
\text { per } 10 \mathrm{~m} \text {. penetration }\end{array}$ & $\begin{array}{ll}2, & 14 \\
2, & 14 \\
2, & 14\end{array}$ \\
\hline Specific Gravity & & 2.60 & 2.75 & 2.70 & Values from present study & $\begin{array}{c}1 \\
\text { Scott }\end{array}$ \\
\hline Total Unit Weight, pcf & & 80 & 118 & $\begin{array}{c}101 \\
(96) \\
{[107]}\end{array}$ & $\begin{array}{l}\text { DSDP values, } 0 \text { to } 200 \mathrm{~m} \text {. } \\
\text { Increase of about } 0.65 \mathrm{pcf} \\
\text { per } 10 \mathrm{~m} \text {. penetration }\end{array}$ & $\begin{array}{l}15 \\
15 \\
15\end{array}$ \\
\hline $\begin{array}{l}\text { Grain Size, mm } \\
\quad \text { Forams } \\
\text { Nannos }\end{array}$ & & $\begin{array}{r}10 \\
1\end{array}$ & $\begin{array}{r}2000 \\
15\end{array}$ & & $\begin{array}{l}\text { Will vary considerably with } \\
\text { water depth and location }\end{array}$ & \\
\hline $\begin{array}{l}\text { Atterberg Limits } \\
\text { Liquid Limit } \\
\text { Plastic Limit } \\
\text { Plasticity Index }\end{array}$ & & $\begin{array}{l}\text { non- } \\
\text { plastic } \\
0\end{array}$ & $\begin{array}{r}200 \\
90 \\
110\end{array}$ & & $\begin{array}{l}\text { Pure ooze is essentially non- } \\
\text { plastic. Max. values given } \\
\text { reflect clay mineral content } \\
\text { of ooze. }\end{array}$ & $\begin{array}{l}3 \\
\text { Keller \& } \\
\text { Bennett }\end{array}$ \\
\hline \multicolumn{7}{|l|}{ Strength } \\
\hline Undrained Shear, ksf & & (0) & {$\left[\begin{array}{l}(0.60) \\
{[2.2]}\end{array}\right.$} & $\begin{array}{c}\text { limited } \\
\text { data }\end{array}$ & $\begin{array}{l}\text { Due to clay mineral content, } \\
\text { cementation or test confinement }\end{array}$ & $\begin{array}{l}\text { Lee }(76) \\
18\end{array}$ \\
\hline \multicolumn{7}{|l|}{$\phi^{\prime}$, degrees } \\
\hline Nannos & & 30 & 42 & $\longrightarrow$ & 20 degrees for design & 13 \\
\hline Sensitivity & & 5 & 12 & $\begin{array}{c}\text { limited } \\
\text { data }\end{array}$ & & $\begin{array}{l}\text { Noorany } \\
\text { Lee }(76)\end{array}$ \\
\hline Cyclic, Stress Ratio & 0.13 at & 100 сус & & & $\begin{array}{l}\text { Only one test performed; } \\
\text { smallest ratio at seafloor }\end{array}$ & Silva \\
\hline \multicolumn{7}{|l|}{ Elastic Properties } \\
\hline $\begin{array}{l}\text { Poisson's Ratio } \\
E, \text { psi } \\
\text { at } \sigma_{3}, \text { psi }\end{array}$ & * & $\begin{array}{r}0.30 \\
180 \\
\text { at } 5\end{array}$ & $\begin{array}{c}0.43 \\
16500 \\
\text { at } 75\end{array}$ & $\begin{array}{c}0.35 \\
\text { limited } \\
\text { data }\end{array}$ & $\begin{array}{l}\text { Values for non-calcareous silts. } \\
\text { Function of } \sigma_{3} \text {; very } \\
\text { variable }\end{array}$ & $\begin{array}{l}\text { Harr } \\
13\end{array}$ \\
\hline $\begin{array}{l}\text { Consolidation } \\
\mathrm{C}_{\mathrm{c}}\end{array}$ & & 0.15 & 0.91 & $\begin{array}{c}\text { limited } \\
\text { data }\end{array}$ & & 19 \\
\hline
\end{tabular}

*No tests on calcareous ooze

SUMMARY OF REPORTED RESULTS: CALCAREOUS OOZE 


\begin{tabular}{|c|c|c|c|c|c|c|}
\hline \multirow[b]{2}{*}{ Parameter } & \multicolumn{4}{|c|}{ All Penetrations } & \multirow[b]{2}{*}{ Remarks } & \multirow{2}{*}{$\begin{array}{c}\text { Plate } \\
\text { of } \\
\text { Reference }\end{array}$} \\
\hline & $\begin{array}{c}\text { Very } \\
\text { Limited } \\
\text { Data }\end{array}$ & Min. & Max. & Ave. & & \\
\hline Water Content, percent & & 89 & 261 & 135 & DSDP \& present study values & 2,14 \\
\hline Specific Gravity & & 2.30 & 2.61 & 2.45 & Values from present study & 1 \\
\hline Total Unit Weight, pcf & & 77 & 91 & 83 & DSDP values & 15 \\
\hline Atterberg Limits & & & & & Pure ooze is essentially' non- & 3 \\
\hline Liquid Limit & & non- & 198 & & plastic. Max. values given & Lee $(73 c)$ \\
\hline Plastic Limit & & plastic & 124 & & $\overline{\text { reflect clay mineral content }}$ & \\
\hline Plasticity Index & & 0 & 127 & & of ooze. & \\
\hline \multicolumn{7}{|l|}{ Strength } \\
\hline Undrained Shear, ksf & & 0 & 1.40 & limited & Due to clay mineral content, & 18 \\
\hline at penetration, $\mathrm{m}$ & & at 0 & at 200 & data & cementation or test confinement. & 18 \\
\hline$\phi^{\prime}$, degrees & & $\begin{array}{l}36 \\
\text { (re-com }\end{array}$ & $\begin{array}{r}41 \\
\text { acted) }\end{array}$ & $\longrightarrow$ & 20 degrees for design. & 10,11 \\
\hline Sensitivity & * & & & & Probably very sensitive. & \\
\hline Liquefaction & * & & & & Extremely sensitive to liquefaction. & Lee $(73 c)$ \\
\hline \multicolumn{7}{|l|}{ Elastic Properties } \\
\hline Poisson's Ratio & * & 0.30 & 0.43 & 0.35 & Values for non-calcareous silts. & Harr \\
\hline $\begin{array}{l}\text { E, psi } \\
\text { at } \sigma_{3}, p s i\end{array}$ & & $\begin{array}{l}560 \\
\text { at } 25\end{array}$ & $\begin{array}{r}2540 \\
\text { at } 75\end{array}$ & $\begin{array}{c}\text { limited } \\
\text { data }\end{array}$ & $\begin{array}{l}\text { Tests on recompacted ooze, } \\
\text { present study }\end{array}$ & 13 \\
\hline Consolidation & & & & limited & & \\
\hline $\mathrm{C}_{\mathrm{c}}$ & & 0.48 & 2.04 & data & & 19 \\
\hline
\end{tabular}

${ }^{\star}$ No tests on siliceous ooze

SUMMARY OF REPORTED RESULTS: SILICEOUS OOZE 


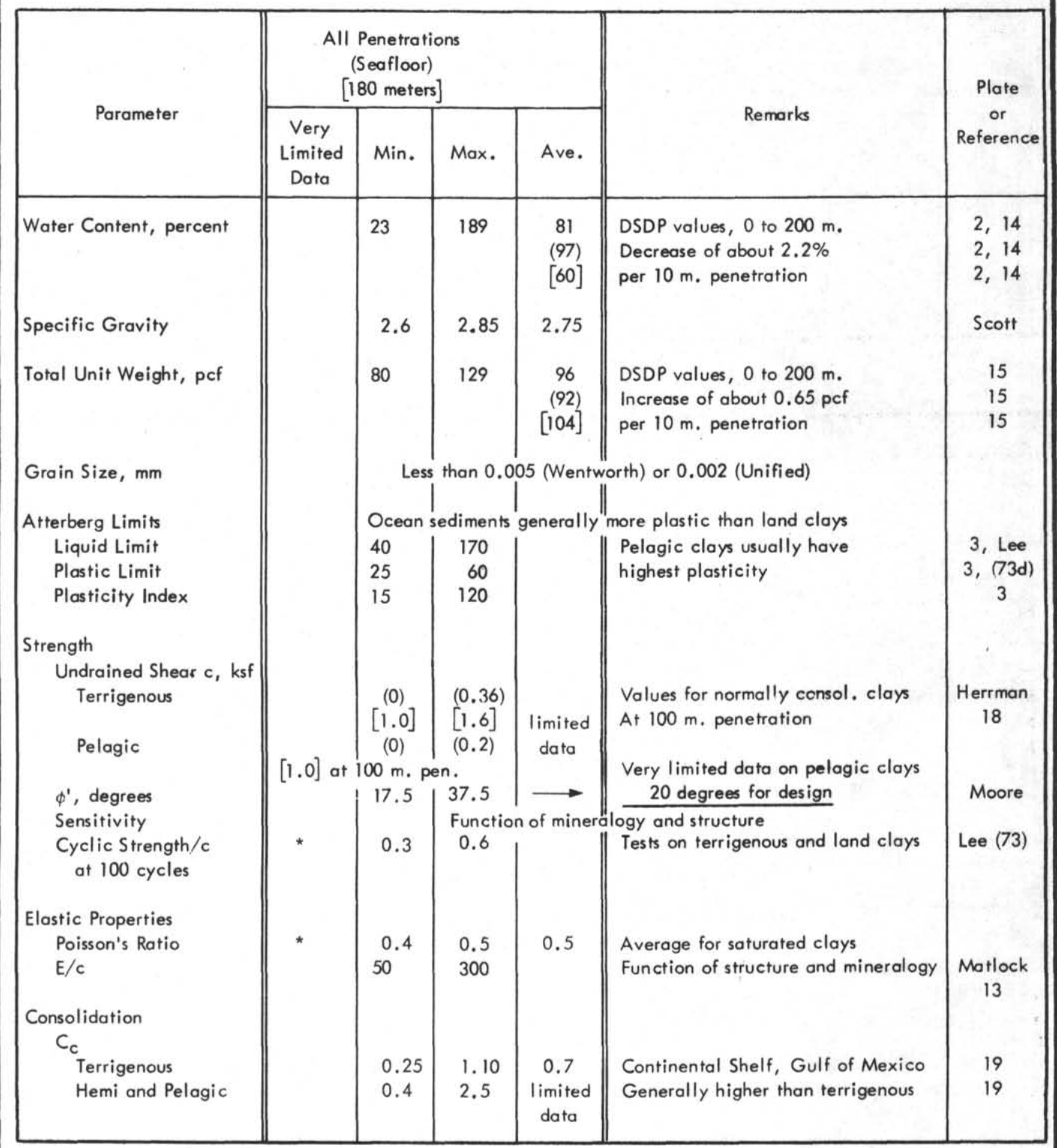

*No tests on continental margin or deep ocean clays

SUMMARY OF REPORTED RESULTS:

CONTINENTAL MARGIN AND DEEP OCEAN CLAYS 
A P P E N D I X A

REFERENCES 
APPENDIX A

REFERENCES

Bennett, R.H., and Keller, G.H., (1973), "Physical Properties Evaluation," Initial Reports of the Deep Sea Drilling Project, Washington, Vol. 16, pp. 513-519.

Bjerrum, L., and Simons, N.E., (1961), "Comparison of Shear Strength Characteristics of Normally Consolidated Clays," Proceedings of the Research Conference on Shear Strength of Cohesive Clays, ASCE, New York, Pp. 711-726.

Bouma, A.H., and Moore, J.C., (1974) "Physical Properties of Deep-Sea Sediments from the Philippine Sea and Sea of Japan," Initial Reports of the Deep Sea Drilling Project, Washington, Vol. 31, pp. 535-568.

Bryant, W.R., Cernock, P., and Morelock, J., (1967), "Shear Strength and Consolidation Characteristics of Marine Sediments from the Western Gulf of Mexico," Marine Geotechnique, University of Illinois Press, pp. 41-62.

Converse, F.J., (1962), "Foundations Subjected to Dynamic Forces," in Foundation Engineering, Leonards, G.A., Editor, McGraw-Hill Book Company, Inc., U.S.A., p. 789 .

Demars, K.R., Nacci, V.A., Kelly, W.E., and Wang, M.C., (1976), "Carbonate Content: An Index Property for Ocean Sediments," Proceedings, Eighth Annual Offshore Technology Conference, Houston, Paper 2627.

Emrich, W.J., (1971), "Performance Study of Soll Sampler for Deep-Penetration Marine Borings," Sampling of Soil and Rock, ASTM STP 483, American Society for Testing and Materials, pp. 30-50.

Finn, W.D.L., Byrne, P.M., and Emery, J.J., (1971), "Engineering Properties of a Marine Sediment," Proceedings, International Symposium on the Engineering Properties of Sea-Floor Soils and their Geophysical Identification, sponsored by UNESCO, National Science Foundation, University of Washington, pp. 110120 .

Fukuoka, M., and Nakase, A., (1973), "Problems of Soil Mechanics of the Ocean Floor," Proceedings, Eighth International Conference on Soil Mechanics and Foundation Engineering, Moscow, Vol. 4.2, pp. 205-220.

Griffin, J.J., Windom, H., and Goldberg, E.D., (1968), "The Distribution of Clay Minerals in the World Oceans," Deep-Sea Research, Vol. 15, pp. 433-459.

Hamilton, E.L., (1964), "Consolidation Characteristics and Related Properties of Sediments from Experimental Mohole (Guadalupe Site)," Journal of Geophysica1 Research, Vo1. 69, No. 20, pp. 4257-4269.

Hanna, T.H., and Adams, J.I. (1968), "Comparison of Field and Laboratory Measurements of Modulus of Deformation of a Clay," Highway Research Record, No. 243, pp. 12-22. 
Harr, M.E., (1966), Foundations of Theoretical Soil Mechanics, McGrawHi11 Book Company, Inc., U.S.A.

Herrmann, H.G., Raecke, D.A., and Albertsen, J.D., (1972), "Selection of Practical Seafloor Foundation Systems," Technical Report R 761, Naval Civil Engineering Laboratory, Port Hueneme, California.

Hvorslev, M.J., (1949), "Subsurface Exploration and Sampling of Soils for Civil Engineering Purposes," Report of Committee on Sampling and Testing, Soll Mechanics and Foundation Division, ASCE.

Keller, G.H., (1969), "Engineering Properties of some Sea-Floor Deposits," Journal of the Soil Mechanics and Foundation Division, ASCE, Vol. 95, No. SM6, pp. 1379-1392.

Keller, G.H., (1971), "Engineering Properties of Greenland and Norwegian Basin Sediments," Proceedings, First International Conference on Port and Ocean Engineering under Arctic Conditions, Technical University of Norway, Vo1. 2, pp. 1285-1311.

Lambe, T.W., (1951), Soil Testing for Engineers, John Wiley and Sons, Inc., New York.

Lambe, T.W., and Whitman, R.V., (1969), Soil Mechanics, John Wiley and Sons, Inc., New York.

Lee, H.J., (1973a), "In Situ Strength of Seafloor Soil Determined from Tests on Partially Disturbed Cores," Technical Note N-1295, Naval Civil Engineering Laboratory, Port Hueneme, California.

Lee, H.J., (1973b), "Measurements and Estimates of Engineering and Other Physical Properties, Leg 19," Inttial Reports of the Deep Sea Drilling Project, Washington, Vo1. 19, pp. 701-719.

Lee, H.J., (1973c), "Engineering Properties of some North Pacific and Bering Sea Soils," Technical Note N-1283, Naval Civil Engineering Laboratory, Port Hueneme, California.

Lee, H.J., (1973d), "Engineering Properties of a Pelagic Clay," Technical Note N-1296, Naval Civil Engineering Laboratory, Port Hueneme, California.

Lee, H.J., (1976), "DOSIST II: An Investigation of the In-Place Strength Behavior of Marine Sediments," Technical Note N-1438, Civil Engineering Laboratory, Port Hueneme, California.

Lee, K.L., (1973), "Effect of Cyclic Loading on the Strength of C1ay," Report to McCle1land Engineers, Houston, Texas.

Leonards, G.A., and Altschaeffl, A.G., (1964), "Compressitility of Clay," Journal of the Soil Mechanics and Foundation Division, ASCE, Vol. 90, No. SM5 pp. 133-155. 
Matlock, H., (1970), "Correlations for Design of Laterally Loaded Piles in Soft Clay," Proceedings, Second Annual offshore Technology Conference, Houston, Paper 1204.

McClelland, B., (1966), "The Progress of Consolidation in Delta Front and Prodelta Clays of the Mississipp1 River," Proceedings of the Research Conference on Marine Geotechnique, University of Illinois Press, Pp. 22-40.

Meyerhof, G. G., (1951), "The U1timate Bearing Capacity of Foundations," Geotechnique, 2, pp. 301-332.

Moore, D.G., (1964), "Shear Strength and Related Properties of Sediments from Experimental Mohole (Guadalupe Site)," Journal of Geophysical Research, Vo1. 69, No. 22, pp. 4271-4291.

Noorany, I., (1971), "Engineering Properties of Calcareous Submarine Sediments from the Pacific," Proceedings, International Symposium on the Engineering Properties of Sea-Floor Soils and their Geophysical Identification, sponsored by UNESCO, National Science Foundation, University of Washington, pp. 130-139.

Rocker, K., (1974), "Vane Shear Strength Measurements on Leg 27 Sediment," Initial Reports of the Deep Sea Drilling Project, Washington, Vol. 27, pp. 425-432.

Roth, P.H., and Thierstein, H., (1972), "Calcareous Nannoplankton: Leg 14 of the Deep Sea Drilling Project," Initial Reports of the Deep Sea Drilling Project, Washington, Vo1. 14, pp. 421-453.

Scott, R.F., (1963), Principles of Soil Mechanics, Addison-Wesley Publishing Company, Inc., U.S.A.

Seed, H.B., and Lee, K.L., (1966), "Liquefaction of Saturated Sands during Cyclic Loading," Journal of the Soil Mechanics and Foundation Division," ASCE, Vo1. 92, No. SM6, pp. 105-134.

Sherman, W.C., and Hadjidakis, C.G., (1962), "Engineering Properties of Fine-Grained Mississippi Valley Alluvial Soils, Meander Belt and Backswamp Deposits," Technical Report No. 3-604, U.S. Waterways Experiment Station, Vicksburg, Mississippi.

Silva, A.J., and Beverly, B.E., (1974), "Geotechnical and Dynamic Properties of Calcareous Sediments as Related to the DSDP Re-Entry Cone," Report to Deep Sea Drilling Project, La Jolla, California.

Trabant, P.K., Bryant, W.R., and Bouma, A.H., (1974), "Consolidation Characteristics of Sediment from Leg 31 of the Deep Sea Drilling Project," Initial Reports of the Deep Sea Drilling Project, Washington, Vo1. 31, pp. $\frac{1}{569-572}$.

Thiers, G.R., and Seed, H.B., (1968), "Cyclic Stress-Strain Characteristics of Clay," Journal of Soll Mechanics and Foundation Division, ASCE, Vol. 94, No. SM2, pp. 555-569. 
Valent, P.J., (1974), "Short-Term Engineering Behavior of a Deep-Sea Calcareous Sediment," Technical Note N-1334, Civil Engineering Laboratory, Port Hueneme, California.

Terzaghi, K., and Peck, R.B., (1967), Soll Mechanics in Engineering Practice, John Wiley and Sons, Inc., U.S.A.

Zeevaert, L., (1972), Foundation Engineering for Difficult Subsoil Conditions, Van Nostrand Reinhold Company, U.S.A. 


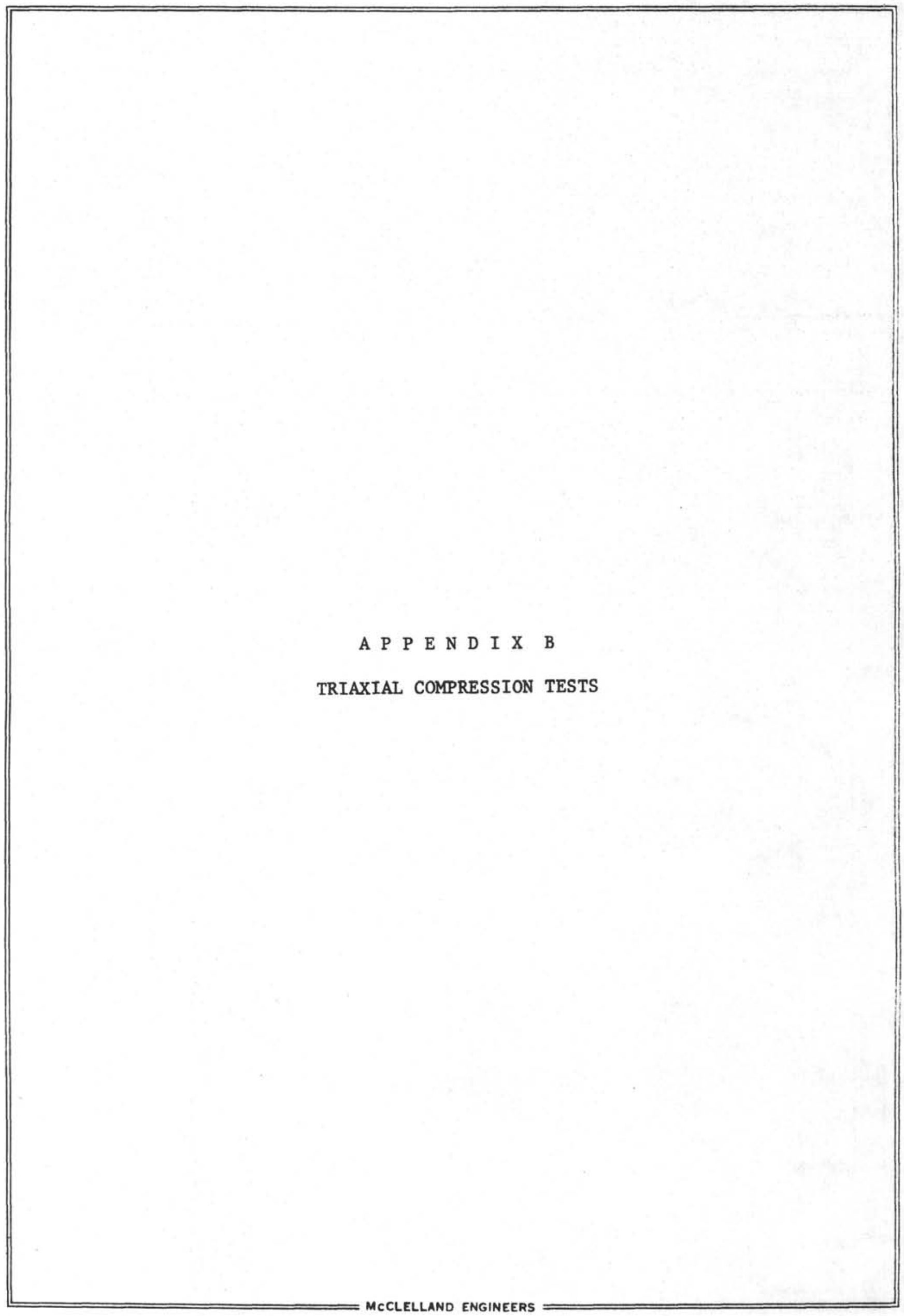


APPENIIX B

CONSOLIDATED-UNDRAINED TRIAXIAL COMPRESSION

TESTS WITH PORE PRESSURE MEASUREMENTS

Basictest Procedure

In this test, a nominally 1-1/2-in.-diameter by 3-in.-1ong cylindrical specimen is enclosed in a thin rubber membrane in a triaxial cell. To ensure saturation, the specimen is subjected to a back pressure slightly greater than the cell pressure; this process dissolves air entrapped in the specimen and between the membrane and the specimen. The extent of the saturation is checked by applying an excess cell pressure and measuring the corresponding pore pressure in the specimen with a differential pressure transducer. The specimen is considered saturated when the measured pore pressure equals the excess cell pressure. After saturation, the cell pressure is increased and the specimen is allowed to fully consolidate under its influence. Drainage is allowed at both the top and bottom ends of the specimen. After consolidation, the specimen is loaded axially at a constant rate of displacement of $0.0024 \mathrm{in}$. per minute with drainage valves from the specimen closed to allow measurement of pore pressure at the base of the sample. The axial load, measured with a 500-1b capacity load ce11, and the recorded pore pressure are plotted continuously during the test. In the single-stage test, the specimen is loaded axially to failure. In the multiplestage tests, the specimen is loaded to the point of incipient failure, the axial load is removed and the cell pressure is increased; the specimen is again allowed to fully consolidate. This cycle is repeated through three stages; in the final stage, the specimen is loaded to failure. Plate A-1 shows a photograph of the testing apparatus and measuring equipment.

\section{Preparation of Test Specimens}

Although the procedure outlined above was followed in all of the triaxial tests, different methods were used to prepare the various specimens for testing. These methods are outlined below.

Method A: Samples 73, 74, and 78. These calcerous ooze samples were obtained from the unsplit Woods Hole core by pushing thin-walled 1-1/2-in.diameter by 3-in.-long stainless steel tubes into the ends of the core 
sections. Each sample was extruded directly from the tube on to a 1-1/2in.-diameter base platen and then enclosed in a rubber membrane. The enclosed sample was carefu1ly weighed and measured and then placed in the cell, ready for testing. Each sample was subjected to one single-stage test.

Method B: Samples 65 and 68. These siliceous ooze samples were air dried for 48 hours and the material was 1ightly crumbled with the fingers to reduce it to individual particle size. The rubber membrane was enclosed in a mold which was set up on the open base of the triaxial cell and the materlal was lightly tamped into the membrane. The specimen was then partially saturated with de-aired water and placed under a small vacuum to facilitate removal of the mold. The top of the cell was clamped on and saturation and subsequent consolidation was commenced. After consolidation of the specimen, the drainage valves were closed and the back pressure and consolidation pressure were zeroed so that the top of the cell could be removed and the dimensions of the consolidated specimen accurately recorded; this was necessary since the dimensions of the specimen before consolidation could not be measured in the normal way due to the method of specimen preparation. After the completion of the single-stage test, the specimen was air dried and the test repeated at a higher consolidation pressure. Both samples were tested in this manner at three consolidation pressures.

Method C: Samples 41 and 50. As in Method B, the rubber membrane was enclosed in a mold and set up on the open base of the triaxial cell. The calcareous ooze material at its natural water content was then tamped into the membrane, the mold removed, and the dimensions of the specimen were carefully measured. The top of the cell was then clamped on and saturation and subsequent consolidation commenced. Multiple-stage tests were performed on each of the samples.

Method D: Samples 55 and 61. These clay samples were kneaded manually at their natural water content into a 1-1/2-in.-diameter by 3-in.long steel mold; care was taken to prevent air bubbles being entrapped in the kneaded materials. Each specimen was extruded from the mold on to a 11/2-in.-diamter base platen, enclosed in a rubber membrane and placed in a triaxial cell where saturation and subsequent consolidation ensued. Multiplestage tests were performed on each of the samples. 
A P P E N D I X C NOTATION 


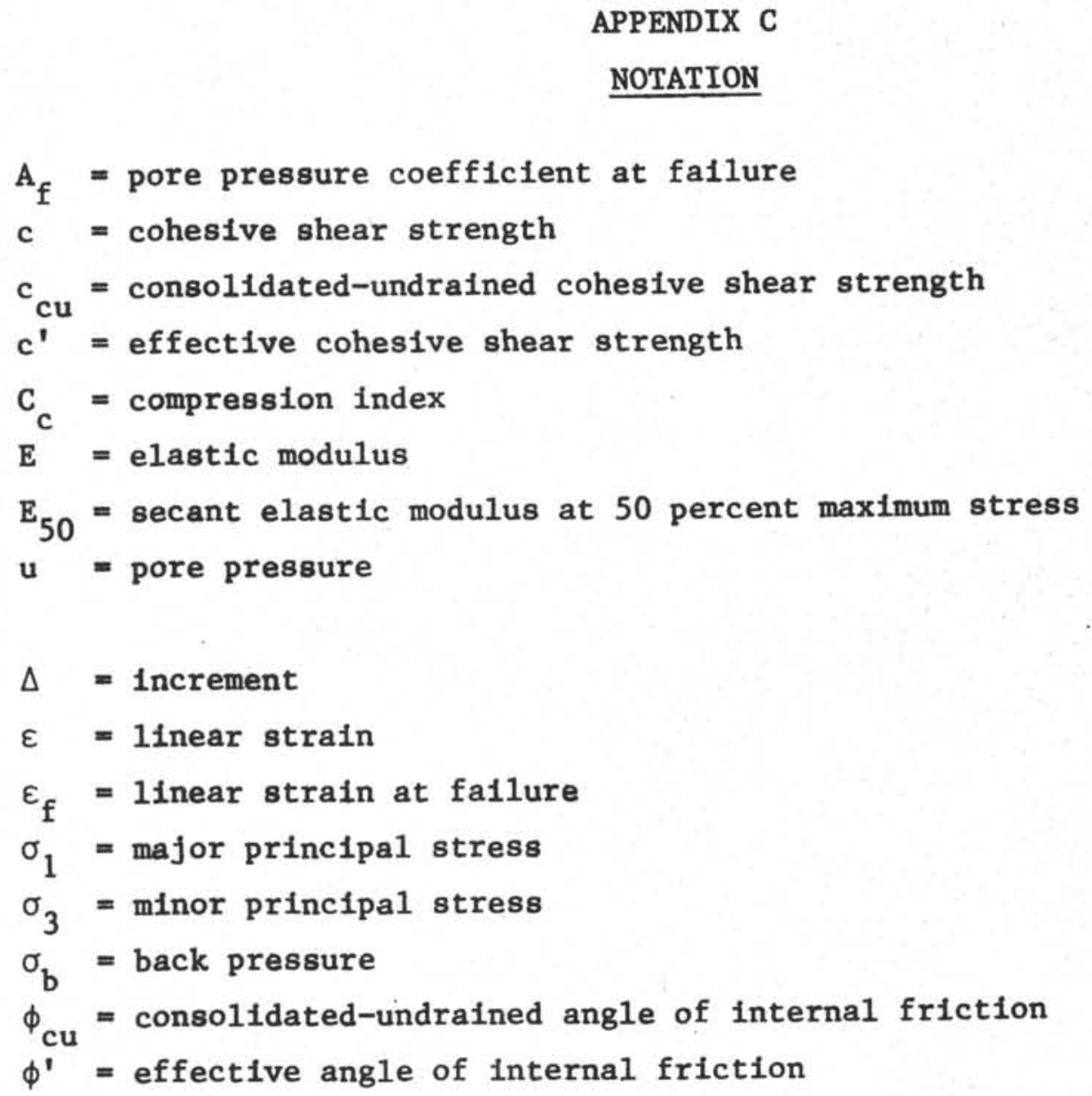


A P P E N D I X

I L L U S T R A T I ON S 


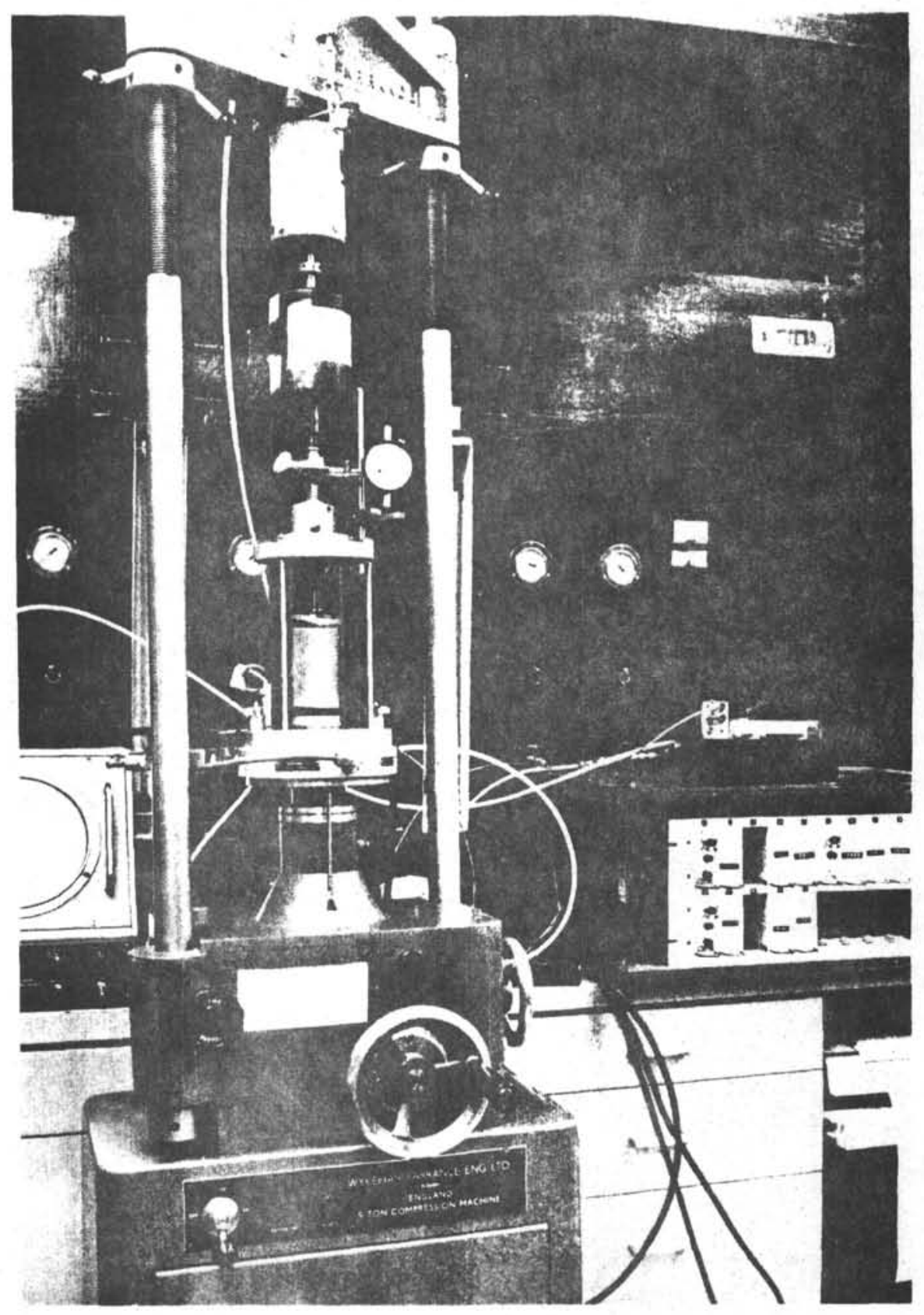

TRIAXIAL TESTING APPARATUS 
BEARING CAPACITY STUDY OF SEAFLOOR SOILS

MID-ATLANTIC RIDGE

ATLANTIC OCEAN

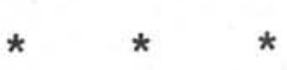

$$
\begin{gathered}
R \text { e } p \circ r t \\
t \circ
\end{gathered}
$$

UNIVERSITY OF CALIFORNIA

DEEP SEA DRILLING PROJECT

La Jolla, California

\author{
b y \\ M C C L E L L A N D E N G I NER S, I N C . \\ Geotechnical Consultants \\ Houston, Texas
}

April 1976 


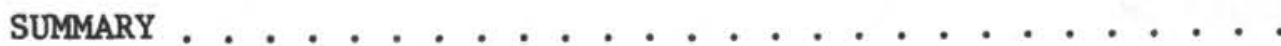

INTRODUCTION

LABORATORY TESTS

SOIL DESCRIPTION

RE-ENTRY CONE

Bearing Capacity without Skirt Extension . . . . Bearing Capacity with Skirt Extension . . . . . . Roughness of Cone . . . . . . . . . . . . . . . Liquefaction . . . . . . . . . . . . . .

CASING CAPACITY . . . . . . . . . . . . . . . . APPLICABILITY OF RESULTS TO OTHER SITES . . . . . . . . . . . INSTALLATION RECOMMENDATIONS . . . . . . . . . . . . . .

\section{ILLUSTRATIONS}

$\underline{\text { Plate }}$

Summary of Classification Test Results . . . . . . . . Consolidated-Undrained Triaxial Test Results . . . . . . Grain Size Curve . . . . . . . . . . . . . . . . . . Diagram of Actual Re-entry Cone . . . . . . . . . . . . Diagram of Cone Assumed for Analysis . . . . . . . . . . . Load versus Penetration of Cone without Skirt . . . . . . . . Load versus Penetration of Cone with Skirt. . . . . . . . . . Ultimate Casing Capacity ................

\section{APPENDIX ILLUSTRATIONS}

Plate

L1thologic Logs and Detailed Descriptions . . . . . . . A-1 and A-2

Smear Slide Descriptions ................ . A-3 Lithologic Symbols . . . . . . . . . . . . . . . A-4 Sediment Classification System ........... . . A-5 


\section{SUMMARY}

A study of seafloor solls from a location on the Mid-Atlantic Ridge was made to provide recommendations concerning the bearing capacity and installation at this site of the drill re-entry cone and attached casing at present being used by the $D / V$ "Glomar Challenger" in connection with the Deep Sea Drilling Project. Physical properties of the seafloor materials were determined by laboratory tests on samples furnished to us from a $21-\mathrm{ft}-1$ ong core from the site and an engineering analysis was performed to develop the required recommendations. The principal findings and conclusions of this study are:

(1) The soil studied is a very fine grained, slight to moderately plastic calcareous ooze with a high content of nannofossils and a significant amount of clay materials.

(2) Triaxial compression test results indicate total and effective angles of internal friction, $\phi$, of the ooze to be in the order of 40 degrees. Based on our offshore experience with clayey silt material, we considered a value for 20 degrees to be a sultable parameter for design purposes.

(3) The ultimate bearing capacity of the soll beneath the cone is presented in terms of maximum load on the cone versus penetration for selected values of $\phi$. Without the skirt extension, the ultimate bearing capacity for $12 \mathrm{ft}$ of vertical cone penetration is approximately $140 \mathrm{kips}$ if $\phi$ of 20 degrees is assumed. With the skirt extension, this bearing capacity is more than doubled.

(4) Effects which will reduce the bearing capacity of the soll beneath the cone, such as 11quefaction and smooth cone surface are discussed. The maximum load for $12 \mathrm{ft}$ of cone penetration is approximately 21 kips if complete liquefaction beneath the cone, with or without the skirt extension, is assumed.

(5) The ultimate capacity of the 16-in.-diameter casing immediately after jetting is presented as a plot of ultimate casing capacity versus casing penetration below the seafloor for selected angles of soil-pile friction, $\delta$. The ultimate casing capacity for $150-\mathrm{ft}$ penetration of the 16-in. casing is approximately $31 \mathrm{kips}$ if $\delta$ equal to 20 degrees is assumed.

(6) No accurate estimate could be made of any possible increase of ultimate casing capacity with time. However, it was considered that groutingin the 16-in. casing could increase the ultimate casing capacity by as much as a factor of 10 over the value for the jetted casing, based on the increase in the coefficient of lateral earth pressure which might be expected from the grouting operation.

(7) Applicability of the cone and casing capacity results to other materials at other sites is discussed.

(8) Recommendations are presented for setting the cone and casing. 


\section{INTRODUCTION}

The dynamically positioned drill ship "Glomar Challenger" has been operated in a world wide program of deep sea coring since 1968. This Deep Sea Drilling Project (DSDP) is part of the National Science Foundation's Sediment Coring Program and is managed by the Scripps Institute of Oceanography of the University of California, San Diego.

The purposes of the study reported here were to develop information on the seafloor materials at a location on the Mid-Atlantic Ridge, and to provide recommendations concerning the bearing capacity at this site of the drill re-entry cone and attached casing at present being used by the $D / V$ "Glomar Challenger". Physical properties of the seafloor materials were determined by laboratory tests taken on samples furnished to us from a core obtained from a location at approximately Latitude $22^{\circ} 58.73^{\prime} \mathrm{N}$ and Longitude $43^{\circ} 30.58^{\prime} \mathrm{W}$. An engineering analysis of this information was performed to develop the required recommendations.

\section{LABORATORY TESTS}

The samples tested in our laboratory were part of a 21-ft-long, 2-7/8-in.-diameter piston core obtained in 14,540 ft of water by the Research Vesse1 "Atlantis 2" under the supervision of Woods Hole Oceanographic Institution. The core was transported to Woods Hole and was subsequently cut into four 5-ft-long sections and one 1-ft-long section. Thin-walled stainless steel tubes, 1-1/2 in. in diameter and $3 \mathrm{in.}$ in length, were pushed into the bottom end of each section to obtain samples of suitable dimensions for triaxial compression testing. These samples, along with two bag samples taken from the core, were transported from Woods Hole to our Houston laboratory for testing.

The laboratory tests consisted of three single-stage consolidatedundrained triaxial compression tests with pore pressure measurements, one hydrometer analysis to determine grain size distribution, two Atterberg limit tests to determine soil plasticity, and two water content determinations. In addition, water content and unit dry weight determinations were made on the 
triaxial test specimens. The results of the water content, Atterberg 1imit and unit dry weight determinations are tabulated on Plate 1. The results of the triaxial tests are presented in the form of stress-strain curves, pore pressure-strain curves and Mohr circles, along with test details on Plate 2. The grain size distribution curve from the results of the hydrometer analysis is presented on Plate 3.

The three stress-strain curves of the triaxial tests presented on Plate 2 indicate a sharp change in slope at about 0.5 percent strain, the slope being reduced by more than a factor of 5 after 0.5 percent strain. This change in slope suggests some rearrangement of the sample structure, possibly involving fracture or breaking of individual particles. The stress-strain relationship is almost linear from 0.5 percent to around 10 percent, after which peak stress is rapidly attained. The Mohr envelopes for total (undrained) stress conditions and effective stress conditions presented on Plate 2 indicate angles of internal friction, $\phi$, of 40 and 42 degrees respectively. However, our offshore experience has shown that, for loose materials which possess grain sizes in the clayey silt range with slight to moderate plasticity, an undrained angle of internal friction or soil-pile friction of not more than 20 degrees is appropriate for use in bearing capacity and casing capacity analyses. Since commonly used bearing capacity theorems are based on the assumption of rigid-plastic, incompressible materials, in cases such as the present where materials are loose and compressible, the mode of failure is altered and the bearing capacity is reduced; the lower design $\phi$ value takes account of this reduction.

\section{SOIL DESCRIPTION}

The foundation materials consist mainly of light yellowish-brown calcareous ooze down to the $21-\mathrm{ft}$ penetration of the core. Generally, nannofossils account for over 50 percent of the material, with clay averaging around 25 percent; forams and manganese micro-nodules were encountered at several different penetrations. The material displayed slight to moderate plasticity and had a very fine-grained texture, with all of the material passing the No. 200 sieve ( 74 microns) and about 50 percent finer than 2 
microns (clay size). The lithologic logs, detailed descriptions, smear slide descriptions and symbols prepared by Woods Hole Oceanographic Institution are reproduced in the appendix on Plates A-1 through A-5.

\section{RE-ENTRY CONE}

\section{Bearing Capacity without Skirt Extension}

The re-entry cone is shown on Plate 4a. At the top, it is $14.7 \mathrm{ft}$ in diameter and leads, at the base, into a 24-in.-diameter diverter packoff assembly. For simplification of analysis, the cone was assumed to be as shown on Plate 4b. The ultimate bearing capacity of the soil beneath the cone ignoring any effect due to the skirt extension was determined from the following equation:

$$
Q_{u}=0.3 \gamma^{\prime} B N_{\gamma} A_{c}+\gamma^{\prime} V-\cdots
$$

where $Q_{u}=u l t i m a t e$ bearing capacity

$\gamma^{\prime}=$ submerged unit weight of the soil

$B=$ diameter of cone at seafloor level $\mathrm{N}_{\gamma}=$ bearing capacity factor (function of angle of internal friction

$A_{c}=$ cross-sectional area of cone at seafloor level

$\mathrm{V}=$ volume of soil displaced by penetrating cone

The ultimate bearing capacity as used here is the maximum load which the soil will sustain before bearing capacity failure occurs; no factor of safety is included in this term.

The results of the bearing capacity analysis using equation (1) are presented on Plate 5 in terms of maximum load on the cone versus penetration of the cone below seafloor level for different angles of internal friction, $\phi$, of the foundation material. A submerged unit weight of 35 pounds per cublc $\mathrm{ft}$ is assumed for the calcareous ooze. Since the load due to the suspended casing will be placed on the cone over a very short period of time, the undrained angle of friction, $\phi$, should be used for the analysis. As shown on Plate 5, the ultimate bearing capacity beneath the cone at 12-ft vertical penetration, (1.e. with approximately 9 in. of cone still above the ocean floor), is about $140 \mathrm{kips}$ if a value for $\phi$ of 20 degrees is assumed for 
the calcareous ooze. Plate 2 shows that the pore pressures generated near sample fallure during the triaxial tests were comparatively small in relation to the deviator stresses; this suggests that little, if any, increase in the bearing capacity of the cone would be experienced with time.

\section{Bearing Capacity with Skirt Extension}

As can be seen on Plate 4a, a 14-ft-diameter skirt extension is attached to the lower part of the cone. This extension is intended primarily as a stabilizer; it is our understanding that it has not been designed structurally to necessarily withstand high potential reaction loads from the seafloor. However, we have analyzed the ultimate bearing capacity of the soll beneath the cone plus the skirt extension on the assumption that these units will not fail structurally.

Plate $4 \mathrm{~b}$ shows the geometry of the cone and skirt assumed in the analysis. The ultimate bearing capacity of the soil beneath the skirt and cone was determined from the following equation:

$$
Q_{u}=0.3 \gamma^{\prime}{ }_{B N} \gamma^{A}+\gamma^{\prime} D_{f}\left(N_{q}-1\right) A+\gamma^{\prime} V
$$

where $Q_{u}=$ ultimate bearing capacity

$\gamma^{\prime}=$ submerged unit weight of soil

$B=$ diameter of skirt extension

$D_{f}=$ depth of skirt extension tip below seafloor level $\mathrm{N}_{\gamma}$ and $\mathrm{N}_{\mathrm{q}}=$ bearing capacity factors (functions of the angle

$A=$ projected area of skirt extension

$\mathrm{V}=$ volume of soil displaced by penetrating cone

The ultimate bearing capacity as used here is the maximum load which the soil will sustain before bearing capacity failure occurs; no factor of safety is included in this term.

The results of the bearing capacity analysis using equation (2) are presented on Plate 6 in terms of the maximum load on the cone versus penetration of the cone below seafloor level for different angles of internal friction, $\phi$, of the foundation material. Assumptions which were made to obtain the Plate 6 curves are (1) the submerged unit weight of the calcareous 
ooze is 35 pounds per cublc $\mathrm{ft}$, (2) the increase in ultimate bearing capacity 1s approximately linear as the skirt penetrates from its extremeties at $1 \mathrm{ft}$ above cone tip to where the skirt joins the cone body at $4 \mathrm{ft}$ above cone tip, (3) soil is trapped beneath the skirt extension and forms an effective 14-ft-diameter footing base about $1 \mathrm{ft}$ above the cone tip, (4) as the skirt penetrates, displaced soll flows round on to the topside of the skirt extension and (5) from the cone tip to $1 \mathrm{ft}$ above the tip, equation (1) is appropriate for computing maximum load.

Comparison of the maximum loads to cause cone penetration without and with the skirt extension (Plates 5 and 6 , respectively), indicates that (1) the load to cause total cone penetration without the skirt is less than the load to cause $4 \mathrm{ft}$ of cone penetration with the skirt, and (2) the load to cause total penetration with the skirt is more than double the load to cause total penetration without the skirt. These results imply that, if the cone with the skirt has penetrated more than $4 \mathrm{ft}$ and the skirt fails structurally under the loading, then sudden complete penetration of the cone may occur with consequent flow of seafloor sediment over the top and down inside the cone.

Roughness of Con e

The results presented on Plate 5 are based on the assumption that the friction angle, $\delta$, between the cone and the calcareous ooze is equal to the internal angle of friction, $\phi$, of the calcareous ooze, i.e., a perfectly rough cone. Meyerhof ${ }^{(1)}$ has shown that the bearing capacity of smoothsurfaced cones, where $\delta$ is less than $\phi$, is smaller than for rough-surfaced cones. The reduced bearing capacity is most pronounced in cones with angles in the order of 60 degrees, (the angle of the re-entry cone). However, if the skirt extension discussed in the previous section is assumed to operate as a structural unit, then the geometry of the cone is altered and the potential decrease due to a smooth-surfaced cone will be mostly eliminated.

(1) Meyerhof, G. G., "The Ultimate Bearing Capacity of Wedge-Shaped Foundations," Proceedings, Fifth International Conference of Soil Mechanics and Foundation Engineering, Paris, 1961, Vo1. 2, pp. 105-109. 
L 1 gue f a c t 1 on

Liquefaction due to the build up of pore pressure can lead to an almost complete $108 s$ of strength of the foundation material. It is known that loose, fine-grained granular solls are particularly susceptible to liquefaction caused by vibration or cyclic loading. Extrapolated results of cyclic triaxial tests on calcareous ooze from the eastern flank of the MidAtlantic Ridge presented by Silva and Beverly ${ }^{(2)}$ indicate that 1iquefaction of the ooze may occur under cyclic loading for stress ratios (i.e., the ratio of half the deviator stress to the consolidation pressure) of greater than 0.05; these results show that the calcareous ooze investigated by Silva and Beverly was highly susceptible to liquefaction under cyclic loading. Although the calcareous oozes used in Silva and Beverly's investigation and in the present study were obtained from different areas of the Mid-Atlantic Ridge, 1t seems probable that the ooze being presently studied is also highly susceptible to liquefaction; however, no information is available at present to indicate if the extent of vibration or cyclic loading caused by the drilling operation would be sufficient to cause liquefaction even in a highly susceptible material. If liquefaction occurs throughout a large mass beneath the cone, the angle of friction of the liquefied ooze can be taken as approximately zero and the bearing capacity of the material will be reduced to the submerged weight of the ooze displaced by the cone. This gives an ultimate bearing capacity beneath the cone, with or without skirt extension, of about $21 \mathrm{kips}$ at $12 \mathrm{ft}$ penetration. It may be noted that the submerged weight of the seafloor equipment used at previous drilling sites, 1.e. the cone plus about $200 \mathrm{ft}$ of 16-in.-diameter casing, is in the order of $22 \mathrm{kips}$, which is only slightly greater than the 21 kips bearing capacity provided by the displaced ooze. This probably is one reason why, at these previous drilling sites, the cone never penetrated completely below the seafloor.

${ }^{(2)}$ Silva, A. J., and Beverly, B. E., "Geotechnical and Dynamic Properties of Calcareous Sediments as Related to the DSDP Re-entry Cone," Report to Deep Sea Drilling Project, July 1974. 


\section{CASING CAPACITY}

The ultimate axial capacity of a 16-in.-diamater casing immediately after it has been jetted to a specified penetration below the seafloor is based on the total skin friction between soil and casing with no factor of safety included, and may be determined from the following expression:

$$
Q_{s}=K \bar{\sigma}_{v} \tan \delta A_{S}
$$

where $Q_{s}=$ ultimate casing capacity

$\mathrm{K}=$ coefficient of lateral earth pressure

$\bar{\sigma}_{\mathrm{v}}=$ effective vertical stress

$\delta=$ angle of friction between foundation soil and casing

$A_{s}=$ surface area of casing

An analysis of the axial capacity of casing installed by jetting was made using equation (3) and the assumption that the foundation material is the same throughout the casing penetration. Information obtained recently from Initial coring operations by the "Glomar Challenger" at the site being studied does indicate that, in fact, nanno ooze exists throughout the casing penetration. The results are presented on Plate 7 in terms of ultimate casing capacity immediately after the jetting operation versus casing penetration below seafloor level for selected values of $\delta$. The results shown on Plate 7 assume a submerged unit weight of 35 pounds per cubic $\mathrm{ft}$ for calculating vertical stress and a coefficient of lateral earth pressure of 0.05 . This coefficient of lateral earth pressure, although based on load tests on jetted piles in sand ${ }^{(3)}$, is the only value avallable to date from in situ tests on jetted piles in granular materials.

Assuming an angle of friction $\delta$ between casing and ooze of 20 degrees, the ultimate casing capacity immediately after jetting will be about 31 kips for $150 \mathrm{ft}$ of casing. Any increase of this capacity with time will be a function of the ability of the jetted material around the pile wall to settle back against the pile. In the present state of the art, no theoretical nor

(3) McClelland, B., "Design of Deep Penetration Piles for Ocean Structures," Journal of the Soil Mechanics and Foundation Division, ASCE Vol. 100, No. GT7, July 1974, pp. 705-747. 
test data have been presented to predict the amount of setup, if any, which can be expected with this type of material.

If the casing is grouted in after jetting, a coefficient of lateral earth pressure in the order of 0.5 can be used. This value represents an increase by a factor of 10 over the jetted pile value, and reflects the grout infilling of voids or semi-voids between the casing and the ooze created by the jetting. These voids eliminate transfer of much of the sediment overburden pressure to the pile wall resulting in decreased casing capacity; the grout infilling causes an increase in this transfer with a corresponding increase in casing capacity. The grouting would give an ultimate casing capacity of about $310 \mathrm{kips}$ at $150-\mathrm{ft}$ penetration, if $\delta$ is assumed equal to 20 degrees.

\section{APPLICABILITY OF RESULTS TO OTHER SITES}

The analysis of cone and casing capacity presented in this study is based on soil parameters derived from laboratory tests performed on samples obtained from the study site; the results of the analysis should, therefore, be applied only to this site. However, some generalizations which may be made regarding the relevance of these results to other materials at other sites are included below.

(1) The water content and unit weight values of the material at the Mid-Atlantic Ridge site being studied are close to the overall average water content and unit weight values of over 300 samples of calcareous ooze cored worldwide by DSDP, and analyzed in our Report No. 175-192. The results presented in the present report are, therefore, probably applicable to many calcareous oozes. However, the properties of these oozes vary widely from site to site. Thus, the results presented here may be used as a guide only for calcareous oozes with water contents and plasticity indices similar to or lower than, and unit weights similar to or higher than, the material being studied here. Since the present material is predominantly a nanno ooze comprising very fine particles, the results, when applied to coarser foram ooze whose properties conform with those stated above, may be somewhat conservative. 
(2) Sillceous oozes have generally higher water contents and lower unit weights than calcareous oozes and the results of the analyses presented here therefore probably overestimate the bearing capacity of siliceous oozes.

(3) Since the present analysis is based on the assumption that the material is granular and non-cohesive, the results cannot be applied to cohesive, non-granular materials.

\section{INSTALLATION RECOMMENDATIONS}

(1) When jetting in the casing, minimum possible mud pressure and weight should be used so as to (a) localize the jetting effects on the soil, and (b) prevent hydraulic fracture of the underlying material.

(2) Jetting of the casing should be halted when the cone starts to penetrate the seafloor; this will prevent the jetted mud or seawater, which normally returns to the seafloor up the outside of the casing, from flowing up the underside of the cone and lessening the bearing capacity of the material immediately under the cone.

(3) After required penetration of the casing is reached, jetting should not be continued unless absolutely necessary to clean out the casing; continued jetting will lessen the ultimate casing capacity.

(4) Grouting-in the casing is strongly recommended since this w111 increase the ultimate casing capacity by as much as a factor of ten.

(5) The underside of the cone should be made as rough as possible to obtain maximum bearing capacity. The importance of cone roughness is diminished, however, if the skirt extension on the cone is capable of carrying the bearing load structurally. 
I L LUSTRA T IONS 


\begin{tabular}{|c|c|c|c|c|}
\hline $\begin{array}{c}\text { Penetration, } \\
\text { Feet } \\
\end{array}$ & $\begin{array}{c}\text { Liquid } \\
\text { Limit } \\
\end{array}$ & $\begin{array}{l}\text { Plastic } \\
\text { Limit } \\
\end{array}$ & $\begin{array}{l}\text { In Situ Water } \\
\text { Content, \% } \\
\end{array}$ & $\begin{array}{c}\text { Unit Dry } \\
\text { Weight, Lb/Cu Ft }\end{array}$ \\
\hline 1.0 & & & 87 & 50 \\
\hline 6.0 & 59 & 43 & 60 & 66 \\
\hline 11.0 & 64 & 38 & 63 & \\
\hline 16.0 & & & 57 & 68 \\
\hline
\end{tabular}




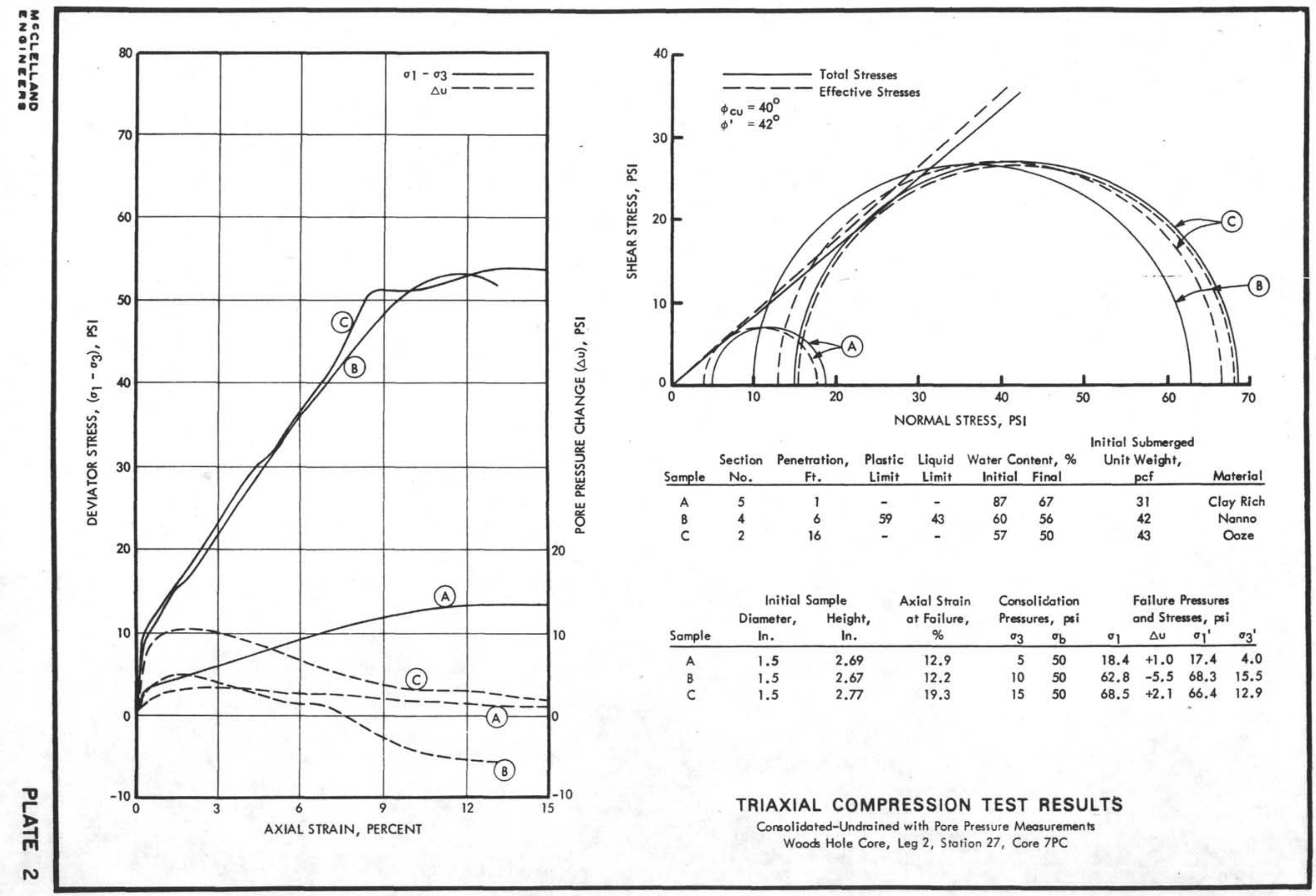





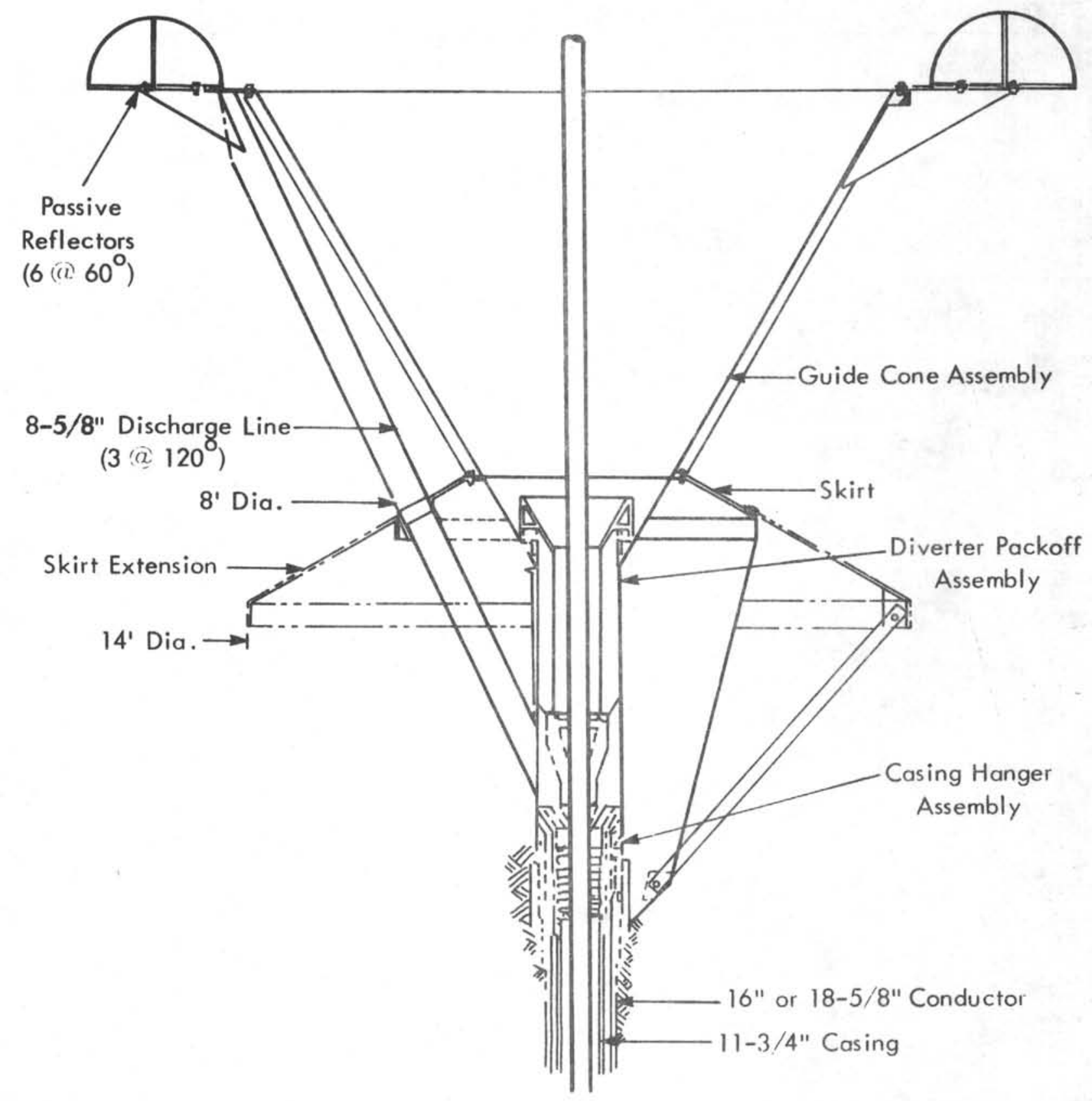

RE-ENTRY GUIDE CONE \& DRILLING ASSEMBLY Scale: 1 in. $=4 \mathrm{ft}$. (approx.) 


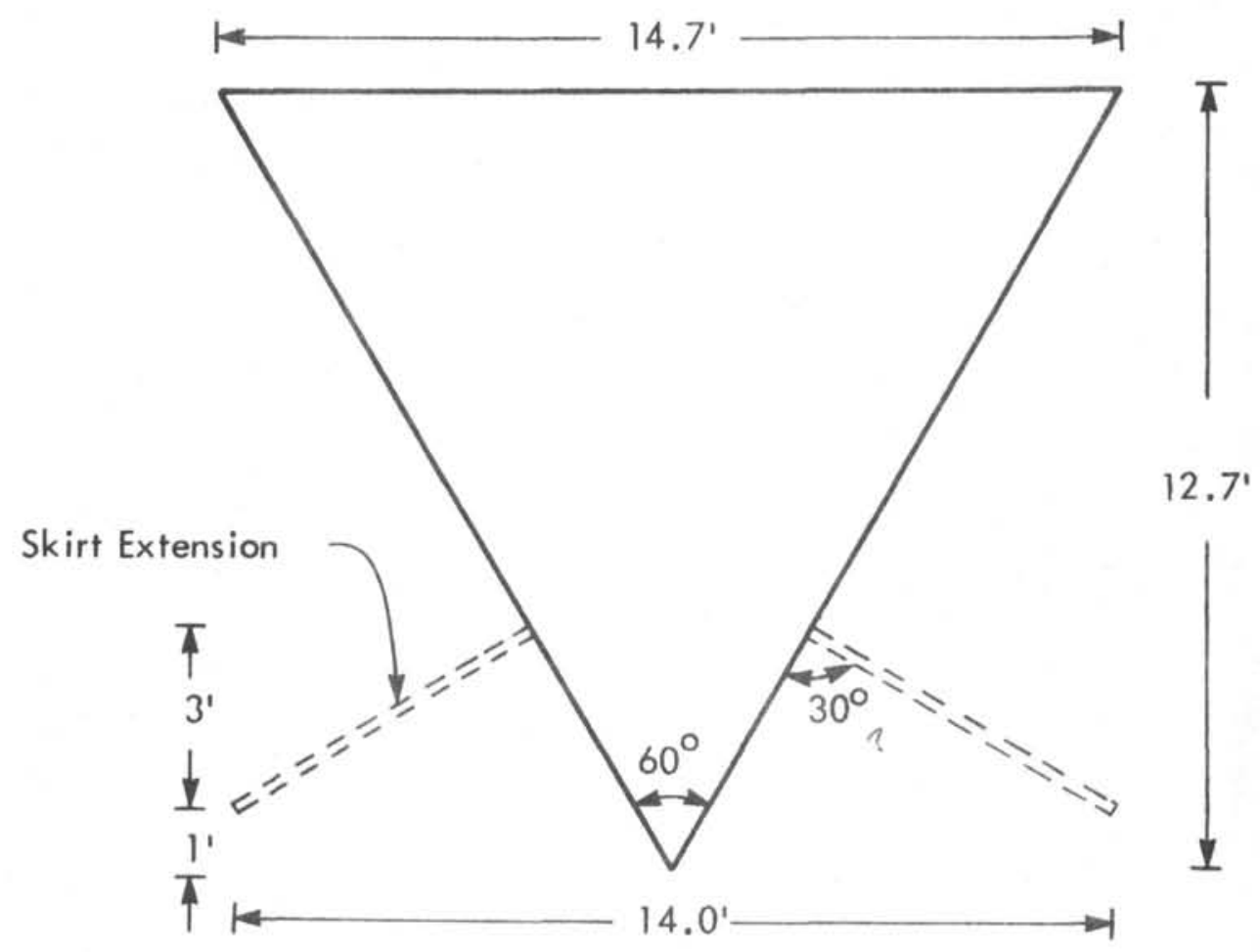

CONE SHAPE ASSUMED FOR ANALYSIS Scale: $1 \mathrm{in} .=4 \mathrm{ft}$. 


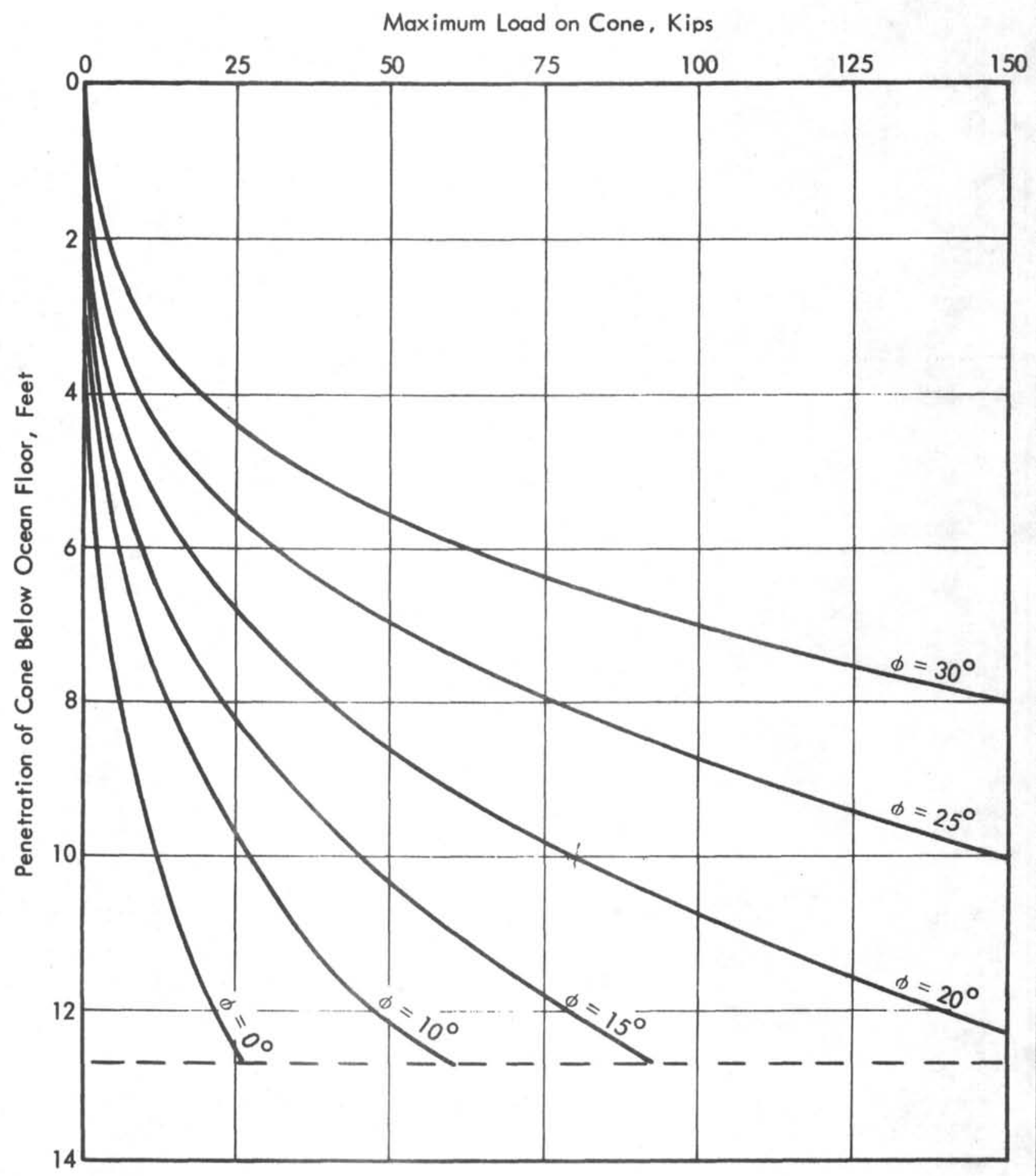

ULTIMATE BEARING CAPACITY OF SOIL BENEATH CONE Without Skirt Extension 


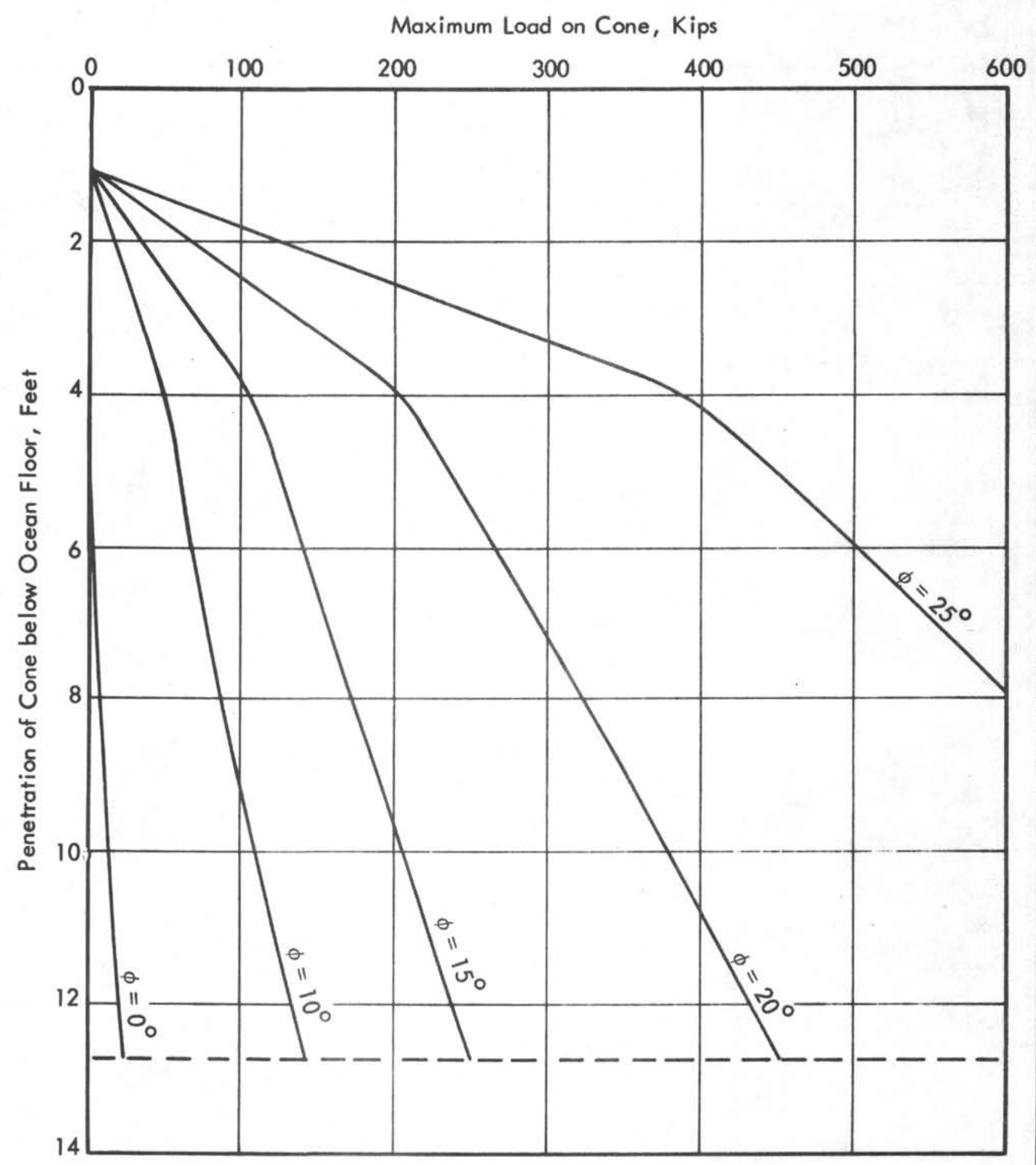

ULTIMATE BEARING CAPACITY OF SOIL BENEATH CONE With Skirt Extension 


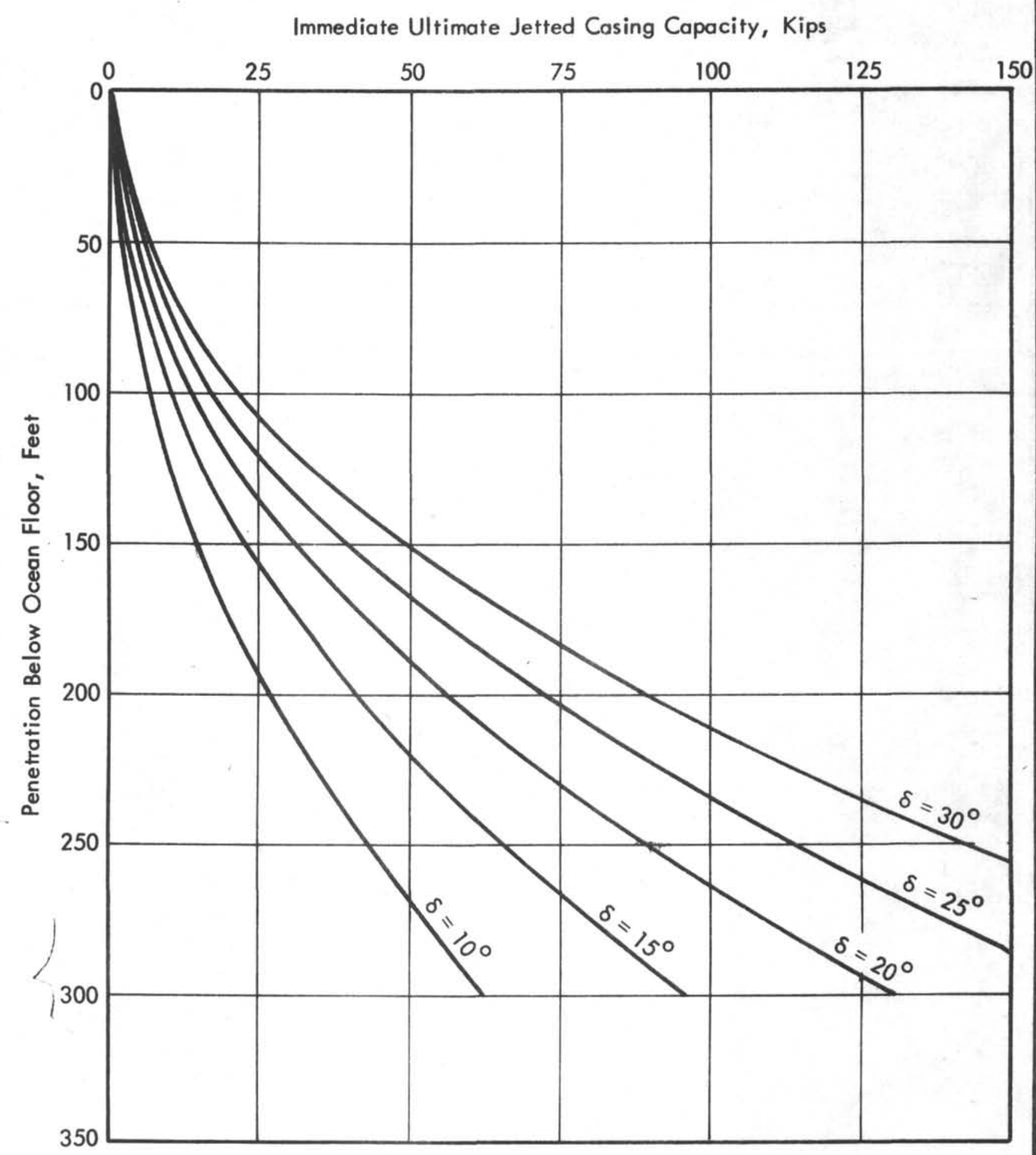

IMMEDIATE ULTIMATE JETTED CASING CAPACITY 16-in.-Diameter Casing 
A P P E N D I $X$

I L L U S T R A T ION S 


\title{
VISUAL CORE DESCRIPTION
}

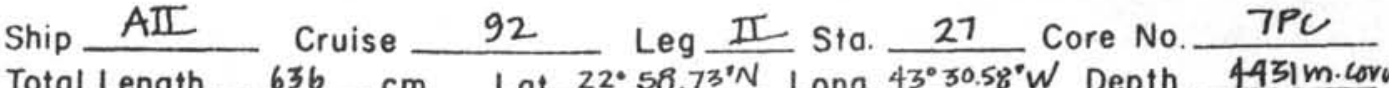
Core condition EXLELCENT. Date Described $50 E C 75$ by f. Grodal Physiographic location CENTER OF MAIN SEDIMENT POND: IPOD SIIE 6. Lithologic

\author{
0 Log Detailed Description
}
firm, tacky lutite with very few forams except in two irregular laminations, $48-50 \mathrm{~cm}$ and $96-97 \mathrm{~cm}$ where very abundant tests are found
CALC OOZE
10 YR $6 / 4$, light yellowish brown
common yellowish brown mottling in the zone 162-174 cm.
firm, slightly silty lutite with abundant forams grading to very few
black Mn-rich flecks are common $160-170 \mathrm{~cm}$
S, horizontal
204-230
CALC OOZE WITH MN MICRO NODULES
10 YR $5 / 4$ yellowish brown grades to $6 / 4$ 1ight yellow- ish brown
common inter-mottling of the colors above in the zone $206-213 \mathrm{~cm}$
firm, smooth lutite with a few scattered forams three well-defined very pale brown foram-rich lamina- tions ( $1 \mathrm{~cm}$ ) occur: $204 \mathrm{~cm}, 220 \mathrm{~cm}, 228 \mathrm{~cm}$; tiny black flecks (Mn?) are common at upper and lower contacts of the laminae
$S$, slightly concave upward




\section{VISUAL CORE DESCRIPTION}

Ship AII Cruise 92 Leg II Sta. 27 Core No. 7PC -

Lithologic

Log

500

6\%)

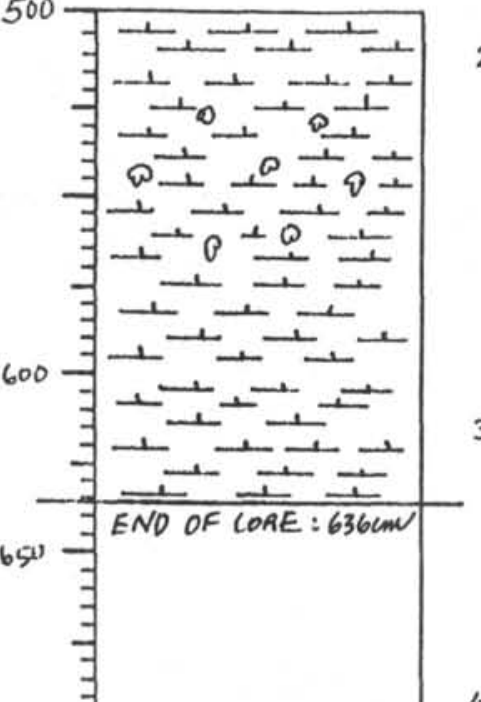

$230-320$

CALC OOZE

10 YR $6 / 4$ light yellowish brown

extensive yellowish brown mottling in the zones 230234 and 297-320 cm; black flecks and tiny Mn-rich pockets are also common in the above

an irregular lens (yellowish brown) of unconsolidated lutite contacts stiff plastic-like foram-rich lutite at $233 \mathrm{~cm}$ : the more compact material continues throughout the unit with decreasing foram content

$320-494$

CAIC OOZE

10 YR $5 / 4$ yellowish brown grades to $6 / 4$ light: yellowish brown

common faint intermottling of the colors above especially in the transitional zone

firm slightly silty lutite with scattered forams S, horizontal

494-636

CALC OOZE

10 YR $5 / 4$ yellowish brown grades to $6 / 4$ light yellowish brown

common faint intermottles of the colors above especially in transitional zone

firm, slightly silty lutite with scattered forams a bit of disturbance appears evident $615-636 \mathrm{~cm}$ end of core 
SMEAR SLIDE DESCRIPTIONS - W.II.0.1. SEDIMENT CORES

Ship:

AII

Core No.

7 PC

Expedition

Station No.

Leg No.

Total Core Length

636

$\mathrm{cm}$

ESTIMATED ABUNDANCES (\%)

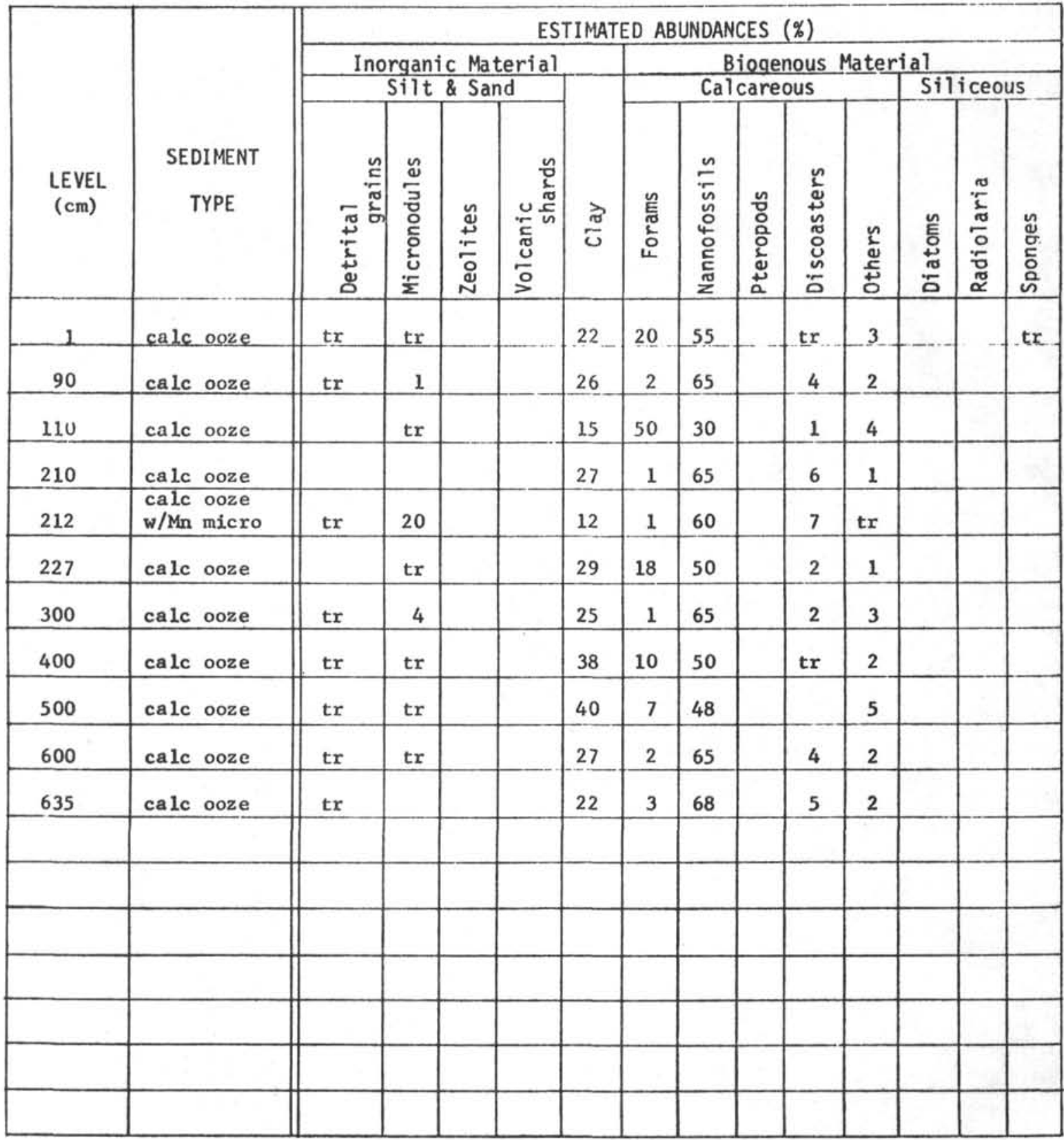




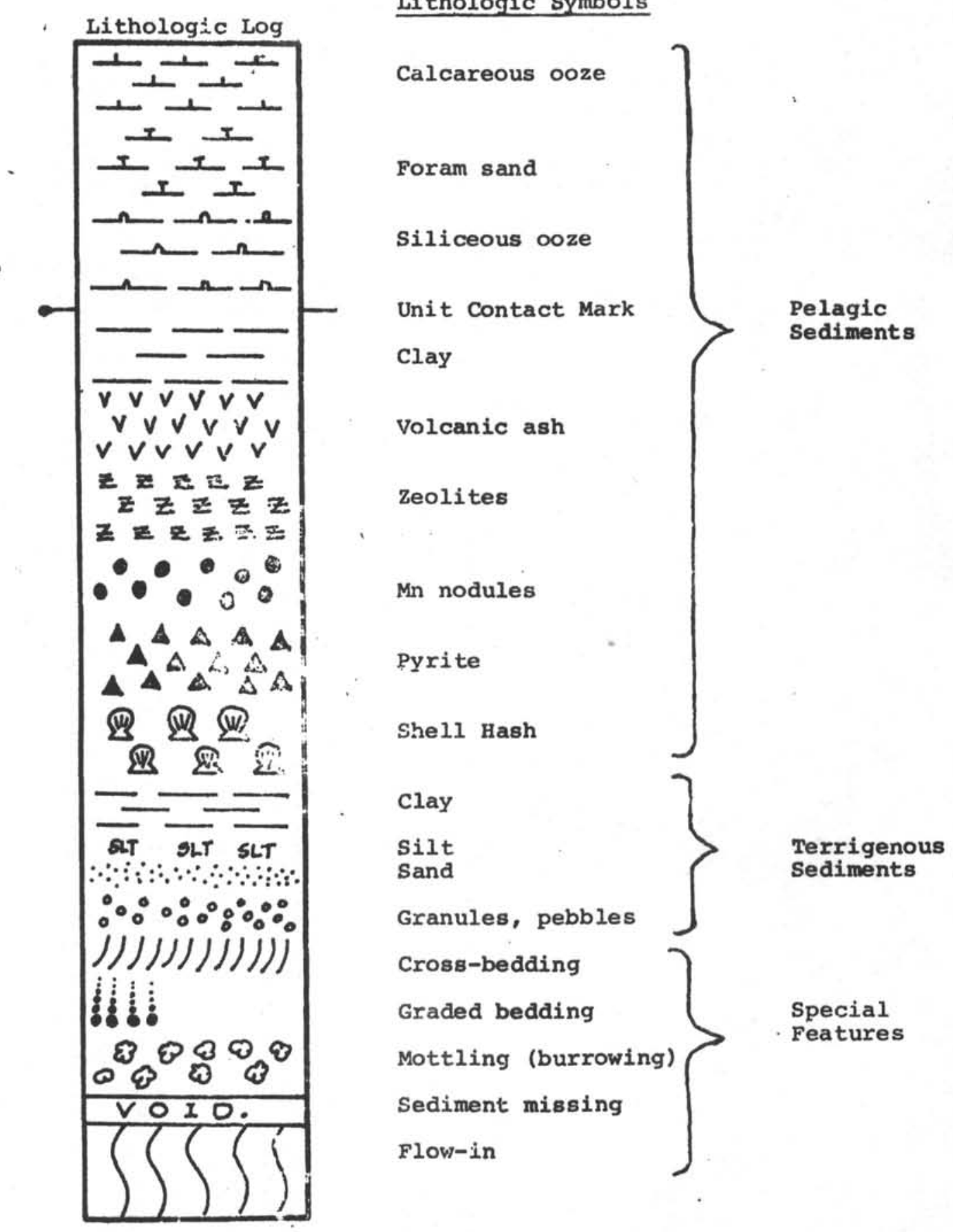




\section{Sediment Classification System}

I. MAJOR SEDIMENT NAME: Based on relative proportion of biogenic material $\left(\mathrm{CaCO}_{3}+\mathrm{SiO}_{2}\right)$ and inorganic material.

A. Oozes: Total biogenic material $\geqslant 30 \%$

$$
\begin{aligned}
& \text { Calcareous ooze: } \quad \mathrm{CaCO}_{3} \gg \mathrm{SiO}_{2} \\
& \text { Calcareous-siliceous ooze: } \mathrm{CaCO}_{3}>\mathrm{SiO}_{2}, \mathrm{SiO}_{2}>58 \\
& \text { Siliceous-calcareous ooze: } \mathrm{SiO}_{2}>\mathrm{CaCO}_{3}, \mathrm{CaCO}_{3}>5 \text { 응 } \\
& \text { Siliceous ooze: } \quad \mathrm{SiO}_{2} \gg \mathrm{CaCO}_{3}
\end{aligned}
$$

B. Clays: Total biogenic material $<308$

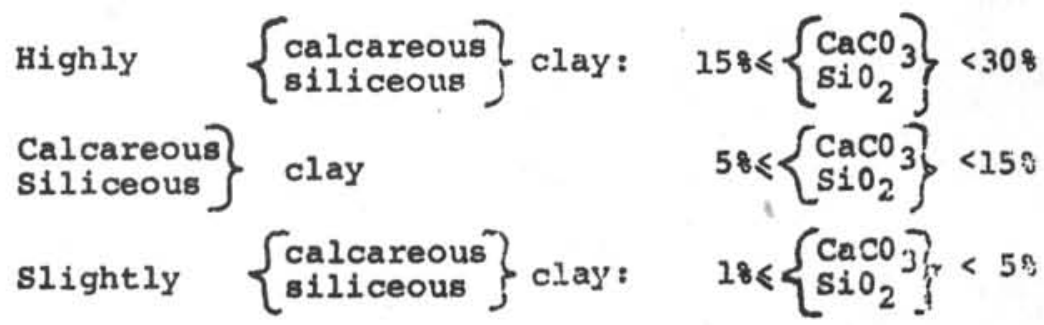

II. SECONDARY SEDIMENT NAMES: Included when silt- or sandsized inorganic components are present in excess of 3.58 .

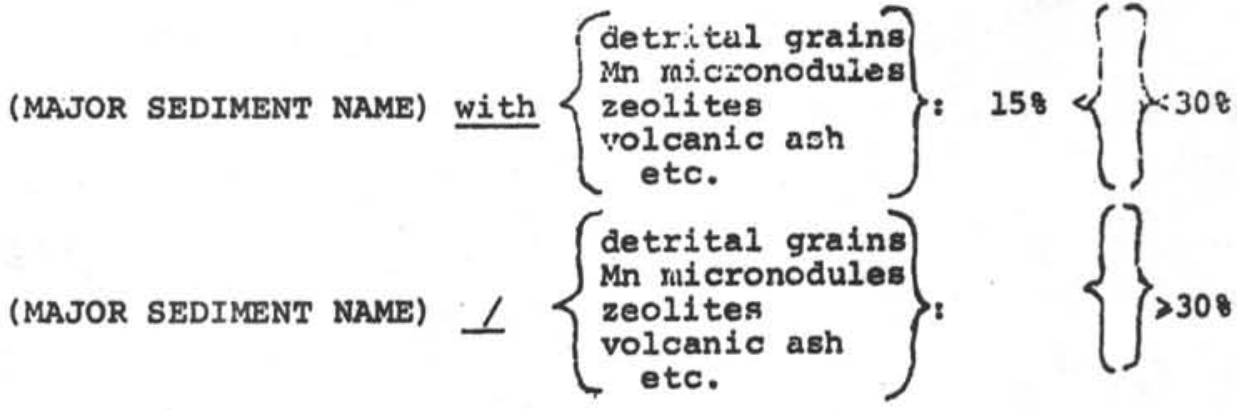

